Caio Augustus Morais Bolzani

\title{
Análise de Arquiteturas e Desenvolvimento de uma Plataforma para Residências Inteligentes
}

Tese apresentada à Escola Politécnica da Universidade de São Paulo para a obtenção do título de Doutor em Engenharia Elétrica 


\section{Caio Augustus Morais Bolzani}

\section{Análise de Arquiteturas e Desenvolvimento de uma Plataforma para Residências Inteligentes}

Tese apresentada à Escola Politécnica da Universidade de São Paulo para a obtenção do título de Doutor em Engenharia Elétrica

Área de concentração:

Sistemas Eletrônicos

Orientador:

Prof. Dr. Marcio Lobo Netto

São Paulo 
Autorizo a reprodução e divulgação total ou parcial deste trabalho, por qualquer meio convencional ou eletrônico, para fins de estudo e pesquisa, desde que citada a fonte.

Este exemplar foi revisado e alterado em relação à versão original, sob responsabilidade única do autor e com anuência de seu orientador.

São Paulo, 10 de janeiro de 2010.

Caio Augustus Morais Bolzani

Prof. Dr. Marcio Lobo Netto

FICHA CATALOGRÁFICA

Bolzani, Caio Augustus Morais

Análise de Arquiteturas e Desenvolvimento de uma Plataforma para Residências Inteligentes - Edição Revisada - São Paulo, 2010. $155 \mathrm{p}$

Tese ( Doutorado ) - Escola Politécnica da Universidade de São Paulo. Departamento de Engenharia de Sistemas Eletrônicos

1.Automação Predial 2.Residência Domiciliar 3.Sistemas de controle I.Universidade de São Paulo. Escola Politécnica. Departamento de Engenharia de Sistemas Eletrônicos II.t. 
Aos meus pais 


\section{AGRADECIMENTOS}

Agradeço aos meus pais, Elio e Beatriz, e à minha irmã Claudia por todo o amor e suporte que recebi para enfrentar essa jornada.

Agradeço ao meu orientador, Prof. Marcio, por ter acreditado no meu trabalho, pela paciência e apoio ao longo destes anos.

Agradeço aos Profs. José Roberto Amazonas, Ricardo Paulino Marques e Fuad Kassab Jr. por todo o apoio e incentivo.

Agradeço a todos os meus amigos da Poli, em especial ao Cristian Montagnoli, Eugênia Mattos, Herbert Camargo e Alberto Nakano pela amizade e pelos inúmeros bate papos que tornaram esses anos muito mais divertidos.

Agradeço ao Antonio Selvatici pelo auxílio na programação dos módulos.

Agradeço à Fundação de Amparo à Pesquisa do Estado de São Paulo (Fapesp) pelo auxílio para o desenvolvimento da plataforma (Projeto PIPE 2007/51787-0). 


\section{RESUMO}

No início do século $\mathrm{XX}$, poucas décadas depois do início da eletrificação das casas, o conceito de uma residência automatizada já era utilizado como símbolo de um futuro livre das tarefas domésticas. No entanto, mesmo com o desenvolvimento de tecnologias de suporte, a automação de residências nunca contemplou uma ampla disseminação e uso. Este trabalho realiza uma análise - social, econômica, tecnológica, cultural e de saúde - da sociedade, desde o início do século XX até os dias atuais, para entender o comportamento humano relativo ao ambiente residencial e identificar as possíveis causas que não favoreceram a implantação de sistemas de controle e automação nestes ambientes. Ele ainda propõe uma arquitetura de sistemas eletrônicos e computacionais para o ambiente residencial, baseada em um conjunto de requerimentos e de abstrações coerentes com o contexto socioeconômico vigente e factível diante das atuais disponibilidades tecnológicas, a fim de direcionar os esforços na área e fomentar o desenvolvimento de aplicações. Adicionalmente, é apresentada uma plataforma de desenvolvimento hardware, firmware e software -, denominada Home Sapiens, cuja concepção, projeto e desenvolvimento foram feitos no contexto desta tese. Baseada em nós de controle distribuídos, ela permite o acesso aos dados provenientes de sensores, a geração de informações de contexto, a identificação de serviços e a manipulação das características do ambiente residencial segundo regras de decisão, planejamento e métodos de aprendizado baseados em técnicas de Inteligência Artificial.

Palavras-chave: Domótica. Automação Residencial. Sistemas de Controle Residenciais. Orientação ao Contexto. Redes de Sensores sem Fio. Zigbee. Home Sapiens. 


\section{ABSTRACT}

In the early twentieth century, a few decades after the beginning of the electrification of houses, the concept of an automated home was used as a symbol of a future free of domestic chores. However, even with the development of supporting technologies, the automation of homes never contemplated a wide dissemination and use. This paper presents an analysis - social, economic, technological, cultural and health - of society, from the early twentieth century to the present day, to understand human behavior on the residential environment and to identify possible causes that did not favor deployment of control systems and automation in these environments. It also proposes an architecture of computer and electronic systems for the residential environment, based on a set of applications and abstractions consistent with the current socioeconomic context and feasible under the available technology in order to direct efforts in the area and promote the development of applications. Additionally, the implementation of a framework - hardware, firmware and software - called Home Sapiens is presented, whose conception, design and development were made in the context of this thesis. Based on distributed control nodes, it provides access to data from sensors, the generation of information of context, the identification of services and handling characteristics of the residential environment in accordance with rules of decision, planning and learning methods based on Artificial Intelligence.

Keywords: Domotics. Home Automation. Home Control Systems. Context-aware Systems. Wireless Sensor Networks. Zigbee. Home Sapiens. 


\section{LISTA DE ABREVIATURAS E SIGLAS}

ANATEL

ATM

$B A N$

CEBus

DI

$D Q D B$

EHSA

EIA

FDDI

$H B S$

HVAC

ISTAG

$L A N$

$M A N$

$N A H B$

PAN

PLC

$S D H$

SHBS

$S M D S$

SONET

WAN
Agência Nacional de Telecomunicações

Asynchronous Transfer Mode

Body Area Network

Consumer Electronic Bus

Dispositivo Inteligente

Distributed Queue Data Bus

European Home Systems Association

Electronic Industries Alliance

Fiber Distributed Data Interface

Home Bus System

Heating, Ventilation, Air Conditioning

Information Society Technology Advisory Group

Local Area Network

Metropolitan Area Network

National Association of Home Builders

Personal Area Network

Powerline Communication

Synchronous Digital Hierarchy

Super HomeBus System

Switched Multimegabit Data Service

Synchronous Optical Networking

Wide Area Network 


\section{LISTA DE FIGURAS}

1 A Domótica, seus componentes e sua relação com outras ciências . . . . . . . 17

$2 \quad$ Nó de controle IEEE $802.15 .4 \ldots \ldots \ldots$

3 Diagrama geral do sistema desenvolvido. . . . . . . . . . . . . . . . . . 24

4 Diagrama simplificado da arquitetura . . . . . . . . . . . . . 82

5 Diagrama de componentes do nó de controle . . . . . . . . . . . . . . . . . 84

6 Modelos de redes de comunicação . . . . . . . . . . . . . . . . . . 85

7 Estrutura de clusters ZigBee (Munk-Stander M.S. (2005)) . . . . . . . . . . . . 94

8 Categorias de contexto $($ Zimmer $(2004)) \ldots \ldots \ldots$. . . . . . . . 100

9 Modelo hierárquico para a detecção de atividades e ativação de atuadores . . . 113

10 Hierarquia de objetos do Context Toolkit (Dey, Salber e Abowd (2001)) . . . 114

11 Modelo de gerenciador de contexto (Zhang et al. (2006)) . . . . . . . . . . . . 114

12 Diagrama de blocos do Home Sapiens . . . . . . . . . . . . . . . . . . . 117

13 Nó de controle ZigBee . . . . . . . . . . . . . . . . . . . . . . . . 119

14 Pacote de dados para a comunicação serial . . . . . . . . . . . . . . . . . 125

15 Interface gráfica do Home Sapiens . . . . . . . . . . . . . . . . . . . . 132

16 Interface gráfica sendo utilizada em uma tela de toque . . . . . . . . . . . . . 133

17 Detalhes do nó de interface e nó de controle . . . . . . . . . . . . . . . . 136

18 Teste da comunicação serial . . . . . . . . . . . . . . . . . . 137

19 Teste da leitura dos sensores . . . . . . . . . . . . . . . . 137

20 Teste do sistema completo f . . . . . . . . . . . . . 138 


\section{LISTA DE TABELAS}

1 Classificação de residências quanto ao nível de controle . . . . . . . . . . . . 30

2 Sistemas de controle . . . . . . . . . . . . . . . . . 91

3 Associação do nó com o local e com sua lista de transdutores . . . . . . . . . . 103 


\section{SUMÁRIO}

1 Introdução $\quad 15$

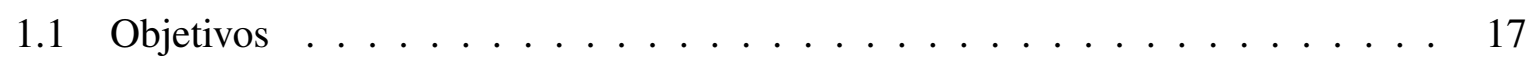

1.2 Conteúdo e Organização . . . . . . . . . . . . . . . . . . . . 19

1.3 Trabalhos Correlatos . . . . . . . . . . . . . . . . . . 19

1.4 Contribuições . . . . . . . . . . . . . . . . . . 21

1.5 Histórico do Desenvolvimento da Tese . . . . . . . . . . . . . . . . . . 21

2 Residências Inteligentes $\quad 26$

2.1 Introdução . . . . . . . . . . . . . . . 26

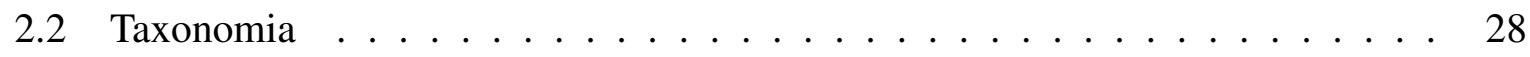

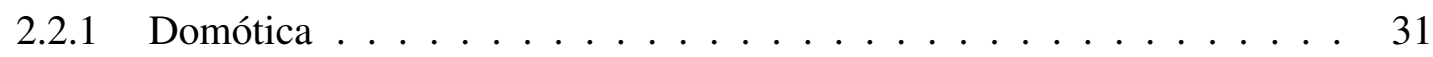

2.2.2 Automação Residencial . . . . . . . . . . . . . . . . . . 31

2.2 .3 O Termo Inteligente $\ldots \ldots \ldots . \ldots \ldots \ldots$

2.2.4 O Conceito de Residências Inteligentes . . . . . . . . . . . . . 33

2.3 As Residências Inteligentes Sob Um Novo Contexto . . . . . . . . . . . . . . 35

$2.3 .1 \quad$ Aspectos Espaciais . . . . . . . . . . . . . . . 36

2.3.2 Aspectos Tecnológicos . . . . . . . . . . . . . . . . . . . . 39

2.3 .3 Aspectos Sociais . . . . . . . . . . . . . . . . . . 47

2.3 .4 Aspectos Ambientais . . . . . . . . . . . . . . . . 51

2.3.5 Aspectos de Saúde . . . . . . . . . . . . . . . . . . 53

2.3.6 Aspectos de Mercado . . . . . . . . . . . . . . . . . . . 55

3 A Evolução da Residência Inteligente $\quad 57$ 
3.1 A Introdução da Lâmpada Incandescente $(1879$ - 1920) . . . . . . . . . . . . . 58

3.2 As Primeiras Casas do Futuro $(1920-39) \ldots \ldots \ldots$

3.3 A Segunda Guerra $(1939-45) \ldots \ldots$. . . . . . . . . . . . . . . 60

3.4 A Maravilha do Pós-Guerra $(1946-59) \ldots \ldots$. . . . . . . . . . . . . . . 61

3.5 A Emancipação da Mulher $(1960$ - 75) . . . . . . . . . . . . . . . . . . . 63

3.6 A Primeira Onda da Automação Residencial $(1975$ - 90) . . . . . . . . . . . . 64

3.6.1 Iniciativas Européias . . . . . . . . . . . . . . 65

3.6.2 Iniciativas Japonesas _. . . . . . . . . . . . . . . . 67

3.6.3 Iniciativas Norte-Americanas . . . . . . . . . . . . . . 68

3.6.4 O Advento dos Computadores Pessoais . . . . . . . . . . . . . 69

3.7 A Era dos Ambientes Inteligentes (1991 - Presente) . . . . . . . . . . . . 71

3.7.1 Iniciativas Acadêmicas . . . . . . . . . . . . . . . . . . 73

3.7.2 Iniciativas Corporativas . . . . . . . . . . . . 76

4 Arquitetura de Sistemas para Residências Inteligentes 79

4.1 Introdução . . . . . . . . . . . . . . . . . . . 79

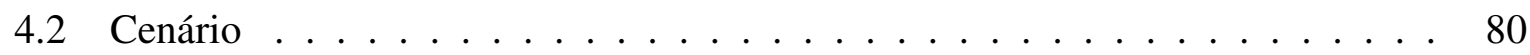

4.3 Descrição Funcional . . . . . . . . . . . . . . . . . . . . . . . . 82

4.4 Camada Física . . . . . . . . . . . . . . . . . . . . . . . . . . . . 82

4.5 Camada de Interface de Transdutores . . . . . . . . . . . . . . . . 83

4.6 Camada de Comunicação . . . . . . . . . . . . . . . . . . . 85

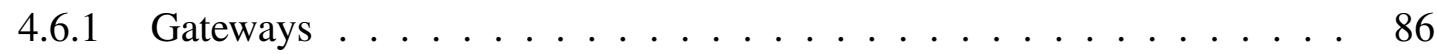

4.7 Camada de Interface Computacional . . . . . . . . . . . . . . . . . . . . 87

4.8 Camada de Serviço . . . . . . . . . . . . . . . . . . . . . . . . . . . 87

4.9 Camada de Contexto . . . . . . . . . . . . . . . . . . 88

4.10 Camada de Conhecimento . . . . . . . . . . . . . . . . 89

4.11 Camada de Decisão . . . . . . . . . . . . . . . . . . . . . . . . . . . 90 
4.12 Camada de Aplicação . . . . . . . . . . . . . . . . . . . . . 92

4.13 Interfaces com o Usuário . . . . . . . . . . . . . . . . . . . . 92

4.14 Sistemas Centralizados x Descentralizados . . . . . . . . . . . . . . . . 93

4.15 Considerações Finais . . . . . . . . . . . . . . . . . . . . . 96

5 Geração e Análise de Informações de Contexto 97

$5.1 \quad$ Introdução . . . . . . . . . . . . . . . . . . . . . . . . . . 97

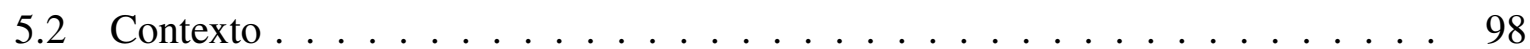

5.3 Dificuldades na Geração de Contexto . . . . . . . . . . . . . . . . . . . . . . . 99

5.4 Categorias de Contexto . . . . . . . . . . . . . . . . . . . 99

5.5 Contexto de Primeira Ordem . . . . . . . . . . . . . . . . . . 101

5.5.1 Geração de Eventos Discretos . . . . . . . . . . . . . . . . . 102

5.5.2 Análise Temporal de Eventos Discretos . . . . . . . . . . . . . . . 104

5.6 Restrições do Domínio de Estados de um Objeto . . . . . . . . . . . . . . 105

5.7 Contexto de Ordem Superior . . . . . . . . . . . . . . . . 108

5.7.1 Detecção de Pessoas . . . . . . . . . . . . . . . . . . . 109

5.7.2 Detecção de Tarefas . . . . . . . . . . . . . . . . . . 109

5.7 .3 Detecção de Rotinas . . . . . . . . . . . . . . . . . . . . . 111

5.8 Gerenciamento de Contexto . . . . . . . . . . . . . . . . . . . 113

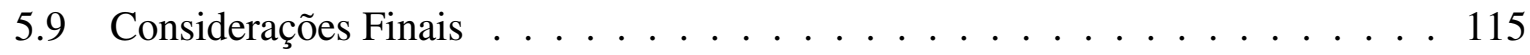

6 Descrição da Plataforma Home Sapiens 116

6.1 Nós de Controle . . . . . . . . . . . . . . . . . . . . . . . . . . . . . . . . 118

6.1 .1 Hardware .......................... 118

6.1 .2 Firmware ........................... 122

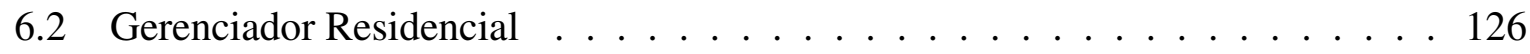

6.3 Gerenciador de Eventos . . . . . . . . . . . . . . . . . . . . 127 
6.4 Descrição das Interfaces de Programa . . . . . . . . . . . . . . . . . . . 127

6.5 Gerenciador de Contexto . . . . . . . . . . . . . . . . . . . . . 128

6.6 Sistemas de Controle . . . . . . . . . . . . . . . . . . . . . . . . . . 129

6.7 Serviços . . . . . . . . . . . . . . . . . . . . 131

6.8 Interface Gráfica do Usuário . . . . . . . . . . . . . . . . . . . . . . . . 132

6.9 Considerações Finais . . . . . . . . . . . . . . . . . . . . . . . . . 134

7 Testes e Análises dos Resultados 135

7.1 Testes do Hardware e do Firmware . . . . . . . . . . . . . . . . . 135

7.2 Teste do Sistema . . . . . . . . . . . . . . . . . 136

7.3 Análise dos Resultados . . . . . . . . . . . . . . . . . . . . . . . . . 139

8 Conclusão 141

8.1 Trabalhos Futuros . . . . . . . . . . . . . . . . . . . . . 142

GLOSSÁRIO $\quad 144$

$\begin{array}{ll}\text { REFERENCIAS } & 145\end{array}$ 


\section{$1 \quad$ Introdução}

Nas últimas duas décadas, a popularização do computador pessoal, da Internet e, mais recentemente, dos dispositivos móveis e redes sem fio tem alterado substancialmente o modo como as pessoas se comunicam, trabalham e se entretem. Essas tecnologias vêm familiarizando as pessoas com novos equipamentos eletrônicos, novas interfaces e com o conceito de interligação de dispositivos em rede.

É natural se esperar também uma mudança profunda nas rotinas domésticas. A ampla introdução de sistemas eletrônicos potencializa o papel das residências que deixam de ser uma estrutura inerte para se tornarem ativas e dinâmicas, com a possibilidade de interagirem com seus moradores e com o mundo externo.

No entanto, a imersão de pessoas em ambientes computacionalmente ativos tem requerido dos desenvolvedores, uma análise balanceada entre a tecnologia e o comportamento do indivíduo, na tentativa de entenderem suas rotinas para criar melhores produtos e serviços. $\mathrm{O}$ desenvolvimento destes ambientes tem envolvido não apenas o estudo dos aspectos tecnológicos, mas também uma análise da influência do modo de vida digital do século XXI na rotina dos moradores de uma residência. Isto pode ser verificado, por exemplo, observando os trabalhos de Venkatesh e Vitalari (1990), Mazumdar et al. (2001) e Ducatel et al. (2001).

Essa mudança de visão tem aumentado as possibilidades de aplicações e benefícios que os sistemas eletrônicos podem proporcionar no ambiente doméstico. Ela foi necessária porque, em uma residência, os moradores interferem e interagem com os sistemas o tempo todo, espontaneamente. Isso cria diversos entraves na concepção de produtos uma vez que devem ser flexíveis o bastante para atender às diferentes necessidades dos usuários e manter um nível adequado de robustez e segurança.

Muitos paradigmas do desenvolvimento de sistemas de controle residenciais tiveram que ser criados, remodelados ou mesmo descartados, fato que trouxe um novo impulso à pesquisa em ambientes inteligentes, conforme observado por Aldrich (2003).

Historicamente, em outros setores, como o da indústria automobilística, a pressão exercida pelo governo e pela comunidade motivou a criação de carros mais eficientes e menos poluidores. Nos últimos anos foram apresentados vários modelos utilizando fontes alternativas de energia que poderão substituir o petróleo e seus derivados usados no transporte rodoviário. O uso de 
novos materiais e de formas construtivas mais modernas tem trazido mais conforto e segurança para os motoristas e passageiros.

As inovações são os elementos propulsores dessas grandes empresas, o diferencial para enfrentar a concorrência. Elas se refletem na crescente introdução de sistemas eletrônicos embarcados que oferecem apoio ao motorista por meio de controle de direção, tração, suspensão, troca de marchas, freios anti-bloqueio e navegação por satélite, para citar alguns exemplos.

Em contrapartida, a tecnologia residencial poderia ser mais explorada. As visões sobre as casas do futuro, desde o início do século passado, envolvem uma situação de grandiosidade e de luxo, um mercado para poucos e abastados. Seus reais benefícios, como o auxílio ao morador nas suas tarefas diárias ou a utilização mais eficiente de recursos, não têm sido devidamente esclarecidos e divulgados.

Os avanços da microeletrônica e a redução dos custos associados ao processo de implantação de softwares em minúsculos chips de silício têm permitido a aplicação de sistemas de controle de processos em situações que, há alguns anos, tinham custo proibitivo. A miniaturização e o crescente acesso às redes de comunicação contribuíram para o surgimento de uma classe de equipamentos mais avançados: os dispositivos inteligentes (DIs) e, com eles, diversas outras aplicações de controle e monitoramento para residências, motivando pesquisas sobre temas até então nunca abordados.

A automação residencial moderna tem aproveitado os amplos recursos dessas tecnologias e retomado, após quase três décadas de resultados inexpressivos, o desenvolvimento de aplicações de comando e monitoramento remotos de equipamentos eletroeletrônicos em ambientes residenciais. Esses avanços tecnológicos associados ao novo contexto socioeconômico e ambiental do século XXI revelam inúmeras oportunidades para o desenvolvimento de sistemas inteligentes para o ambiente residencial. A integração desses sistemas tem mostrado um aumento considerável dos benefícios se comparados com os sistemas isolados, de eficiência limitada.

A automação e o gerenciamento remoto de dispositivos têm sido apontados como ferramentas importantes para uma gestão eficiente da utilização de recursos energéticos e naturais. A possibilidade de monitoramento contínuo e em tempo real do uso desses recursos permite que se desenvolvam serviços efetivos de gerenciamento como detecção imediata de vazamentos, análise de demanda futura, entre outros.

Um outro exemplo são as interfaces humano-máquina que têm sido remodeladas para facilitar o acesso às novas funcionalidades da casa por todos os moradores, sejam eles crianças, adultos, idosos ou portadores de alguma deficiência. Os sistemas de controle residenciais também têm evoluído com o compromisso de não só beneficiar os moradores com o máximo em 
conforto e segurança, mas também utilizar os recursos eficazmente.

A proposta de uma arquitetura de hardware e software tem como finalidade estabelecer critérios e métricas entre fabricantes e consumidores e fomentar o desenvolvimento das várias camadas de serviço que compõem uma residência inteligente: a integração de redes de controle; gerenciamento e análise de sensores e atuadores; interfaces; redes de comunicação; e todos os problemas que envolvem a imersão de pessoas em ambientes computacionalmente ativos. Esse último deflagra uma série de discussões e questões em várias disciplinas quando o comportamento humano é avaliado. Os esforços da Engenharia, Medicina, Ciência da Computação, Inteligência Artificial e Psicologia se somam em uma nova ciência denominada Domótica (Figura 1).

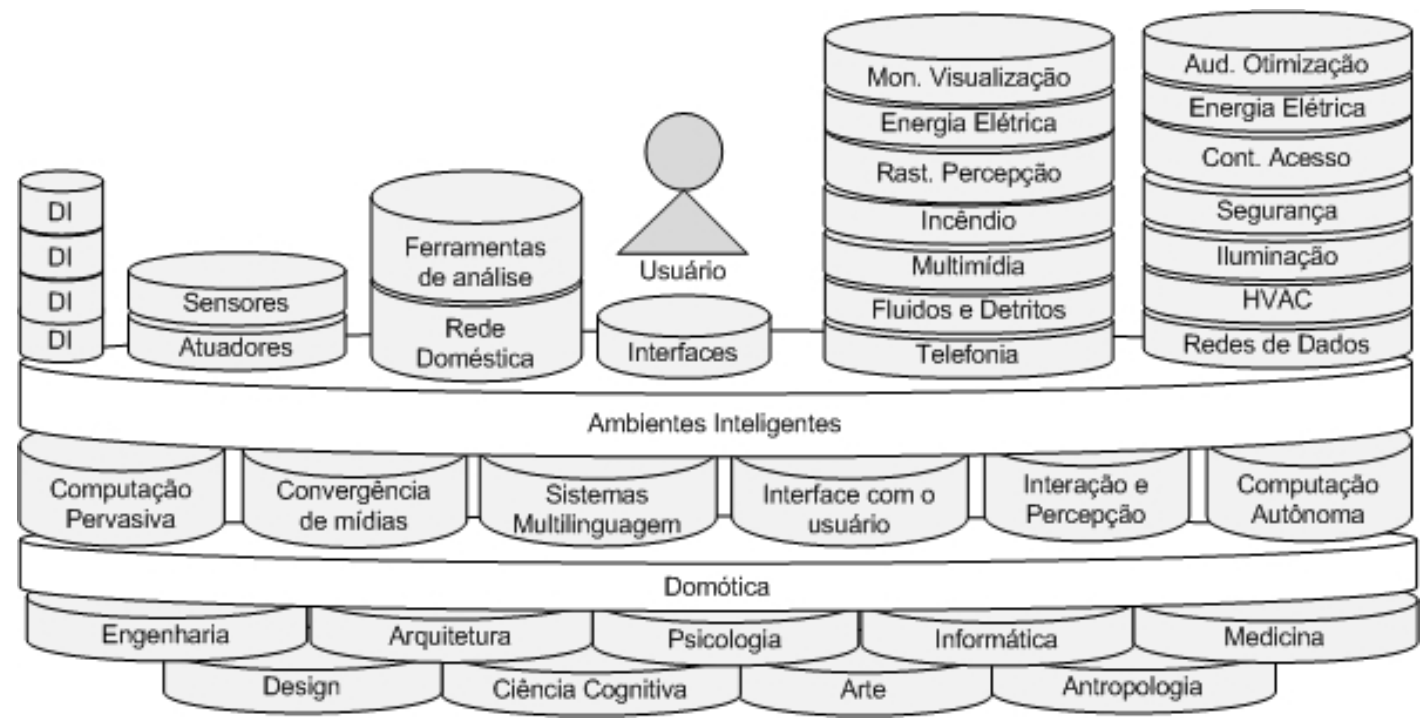

Figura 1: A Domótica, seus componentes e sua relação com outras ciências

Seu caráter multidisciplinar permite uma abordagem mais ampla das necessidades do usuário frente às possibilidades oferecidas pelo mundo digital e suas interações com a residência automatizada. Muito recente, a Domótica ainda carece de formalismos e de metodologias detalhadas para a criação e a implementação de ambientes automatizados e computacionalmente ativos. A insuficiência de métricas, postulados e normas motivam todo o desenvolvimento desse trabalho.

\subsection{Objetivos}

O objetivo deste trabalho é prover uma ampla análise - social, econômica, tecnológica, cultural e de saúde - da sociedade, desde o início do século XX até os dias atuais, para entender o comportamento humano relativo ao ambiente residencial e identificar as possíveis causas 
que não favoreceram a implantação de sistemas de automação nestes ambientes. Baseada nesta análise e nos atuais conceitos de Computação Ubíqua, uma arquitetura de sistemas computacionais e eletrônicos é proposta e formalizada para que fomente estudos, aplicações e métodos de desenvolvimento de uma residência inteligente.

Com o intuito de esclarecer as metas a serem atingidas, uma lista com objetivos específicos está apresentada a seguir:

Quanto aos aspectos sociais, econômicos e culturais: analisar como as mudanças sociais, econômicas e culturais têm alterado a relação entre a tecnologia e o usuário dentro do ambiente residencial e propor aplicações que possam promover vida independente e de melhor qualidade para seus moradores.

Quanto aos aspectos energéticos e ambientais: propor meios para a análise dos padrões correntes de utilização de energia e de recursos no ambiente residencial e sugerir métodos de controle de dispositivos eletroeletrônicos que possam reduzir o impacto ambiental por meio do uso mais racional dos recursos naturais.

Quanto à arquitetura de sistemas: propor e formalizar uma arquitetura que permita monitorar e manipular o mundo físico por meio de sensores e atuadores, gerenciar serviços e criar interfaces de programas para o desenvolvimento de novas aplicações.

Quanto aos usuários e suas rotinas: evidenciar a necessidade da observação das rotinas e classificar os principais métodos de observação. A análise das atividades diárias dos ocupantes de uma residência pode auxiliar na criação de equipamentos, interfaces e sistemas que aprendam, ao longo do tempo, a responder às suas expectativas e aumentar o nível de conforto e segurança no ambiente residencial, com a mínima demanda de energia.

Quanto às redes de transmissão de dados: caracterizar os tipos de redes existentes e relacioná-las diante das necessidades impostas pela demanda de serviços em uma residência inteligente.

Espera-se que os resultados e as considerações obtidas nesse trabalho fomentem o estudo e o desenvolvimento de métodos de construção de residências mais apropriadas ao cenário energético mundial das próximas décadas, utilizando mais racionalmente e eficientemente os recursos naturais e as fontes de energia, bem como, por meio dos avanços tecnológicos, melhorem a qualidade de vida de seus moradores. 


\subsection{Conteúdo e Organização}

Esse trabalho está dividido em oito capítulos, conforme descrição a seguir:

Cap.1 - Introdução sobre os aspectos que motivaram esse trabalho, descrição dos objetivos, das contribuições e dos trabalhos correlatos;

Cap. 2 - Apresentação dos conceitos fundamentais, da taxonomia, das necessidades e desafios do novo contexto socioeconômico, cultural e tecnológico do século XXI e das oportunidades para o desenvolvimento de sistemas eletrônicos e computacionais no ambiente residencial;

Cap.3 - Histórico das residências inteligentes e como tem sido sua evolução em comparação com outras tecnologias;

Cap.4 - Apresentação de uma arquitetura de sistemas de uma residência inteligente, com descrições técnicas e funcionais de transdutores e de redes de comunicação até camadas de alto nível como serviço, contexto, conhecimento e decisão;

Cap.5 - Neste capítulo são descritos os processos de geração e análise de informações de contexto e é evidenciada a importância dessas informações no processo decisório dos sistemas de controle residenciais;

Cap.6 - Apresentação da plataforma de desenvolvimento de aplicações residenciais denominada de Home Sapiens;

Cap.7 - Testes e as análises dos resultados obtidos;

Cap. 8 - Conclusão e trabalhos futuros.

\subsection{Trabalhos Correlatos}

Historicamente, a pesquisa relacionada aos ambientes inteligentes têm enfatizado os aspectos técnicos associados ao controle de dispositivos e à interligação desses dispositivos em rede. Devido às necessidades distintas, duas linhas de pesquisa se formaram: a dos sistemas de controle domésticos e a dos sistemas multimídia.

A pesquisa com sistemas multimídia envolve o desenvolvimento de equipamentos que gerenciam (reproduzem, armazenam, editam) conteúdo de áudio, vídeo e telefonia, a definição de protocolos e mecanismos de transmissão e recebimento dessas informações, técnicas de compressão de dados, entre outros.

A pesquisa de sistemas de controle envolve todas as questões relativas ao gerenciamento de dispositivos eletroeletrônicos no ambiente doméstico, iniciando com a aquisição e o tratamento de dados provenientes de sensores, até a modificação do estado dos atuadores. Esse processo 
envolve o estudo das características desses transdutores, o desenvolvimento de protocolos e mecanismos de transmissão de dados, a criação de métodos de análise e gerenciamento das informações, a criação de interfaces, etc. Muitas aplicações foram criadas baseadas nesses sistemas, como o controle de iluminação e ar-condicionado, monitoramento de pessoas, homecare, e o gerenciamento de energia e recursos naturais.

Nas últimas duas décadas, têm surgido novos modelos de arquitetura de sistemas de controle domésticos capazes de gerenciar uma grande quantidade de informação proveniente de inúmeros dispositivos eletroeletrônicos. Esses modelos demonstram o efeito da influência dos conceitos da Computação Ubíqua no âmbito residencial, que propõem que as pessoas irão viver rodeadas de dispositivos eletrônicos e interagir constantemente com o mundo virtual por meio de múltiplas interfaces.

Essa nova visão despertou a necessidade de uma análise mais profunda das rotinas de cada usuário dentro de sua residência e de como ele reagiria vivendo imerso em um ambiente computacionalmente ativo. Assim, no início dos anos 1990, começam a surgir as primeiras residências-laboratórios, espaços densamente equipados com computadores, redes de comunicação, sensores, atuadores, câmeras, projetores de vídeo e interfaces para o estudo dessas interações e do aprimoramento dos sistemas de controle. As residências-laboratórios têm demandado não apenas o espaço físico para acomodar pesquisadores e equipamentos, mas também toda a infraestrutura de rede, dispositivos e serviços para o desenvolvimento das pesquisas em ambientes inteligentes. É nesse momento que esse trabalho se insere, propondo uma arquitetura e uma plataforma de trabalho para fomentar a pesquisa sobre o tema.

Ele se baseia em algumas iniciativas internacionais como o Intelligent Room do MIT (Massachussets Institute of Technology) (BROOKS, 1997), MavHome da Universidade do Texas (COOK et al., 2003), Gator Tech Smart House da Universidade da Flórida (HELAL et al., 2005), Otis da Universidade de Essex (SHAHI; GARDNER; CALLAGHAN, 2005), Digital Aura da Universidade de Tampere (LUGMAYR; SAARINEN; TOURNUT, 2006), Gaia da Universidade de Illinois (ROMAN C.H., 2002), Aware Home da Universidade da Geórgia (KIDD; ORR; ABOWD, 1999) e Adaptive House da Universidade do Colorado (MOZER, 1998).

Otis, Digital Aura e Gaia são semelhantes por abordar o gerenciamento de conteúdo multimídia em ambientes inteligentes. Intelligent Room e Aware Home incluem um impressionante conjunto de sensores para determinar a localização e as atividades dos usuários. Gator Tech e MavHome definem uma arquitetura e propõem uma plataforma de gerenciamento das informações do ambiente provenientes de sensores. MavHome combina tecnologias de inteligência artificial, bases de dados, computação móvel, robótica, e multimídia para criar uma casa inteli- 
gente. A Adaptive House emprega uma rede neural para controle do aquecimento, ventilação, iluminação e temperatura da água que vai se familiarizando com a rotina de seus moradores e com o objetivo de minimizar custos operacionais.

\subsection{Contribuições}

O conceito de residências inteligentes se refere ao aprimoramento do ambiente residencial, a fim de prover os meios necessários para que seus moradores possam desempenhar suas atividades diárias com aumento da qualidade de vida. Embora essa área de pesquisa tenha grande potencial para trazer benefícios econômicos e sociais, observa-se que vários fatores impediram que ela se tornasse tão abrangente quanto a automação industrial e a comercial.

Esse trabalho identifica esses fatores, analisando os aspectos tecnológicos, sociais, culturais e econômicos que envolvem a complexa arquitetura do ambiente residencial, e sugere novas metodologias de desenvolvimento de equipamentos e sistemas domésticos baseando-se em uma análise detalhada, desde os nós de sensoriamento e controle interligados por uma rede sem fio, até o conceito de contexto, tarefas, rotinas e conhecimento.

Adicionalmente, é apresentada uma plataforma de desenvolvimento - hardware, firmware e software -, denominada Home Sapiens, cuja concepção, projeto e desenvolvimento foram feitos no contexto desta tese. Ela provê acesso aos dados fornecidos por sensores, interligados por nós de controle distribuídos, e permite a criação de algoritmos de decisão, planejamento e métodos de aprendizado utilizando técnicas de Inteligência Artificial, para a manipulação das características do ambiente residencial. Baseada na arquitetura de sistemas aqui descrita, essa plataforma, interamente criada pelo autor deste trabalho ou sob sua supervisão, permite modelar e testar novos métodos de geração de informações de contexto, e criar novos serviços e aplicações fomentando pesquisas sobre o tema.

\subsection{Histórico do Desenvolvimento da Tese}

Nos últimos anos, a pesquisa de ambientes inteligentes tem sido considerada relevante como agente transformador das relações socioeconômicas e até políticas para o século XXI. Na Europa, por exemplo, o Information Society Technologies Advisory Group (ISTAG), um grupo formado pela Comissão Européia para tratar assuntos relacionados à sociedade da informação, enfatizou que a qualidade da vida no futuro dependeria diretamente do suporte que a tecnologia de ambientes pudesse prover. $\mathrm{O}$ conceito transcendia as interações do homem com a residência para qualquer ocasião de interatividade do homem com o meio (DUCATEL et al., 2001). 
Outro aspecto importante que mostra a relevância do tema é a grande quantidade de conferências realizadas e trabalhos científicos publicados no período. Apenas nessa década, mais de 8.000 artigos foram catalogados nas bases de dados do Institute of Electrical and Electronics Engineers (IEEE), Springer Science + Business Media (Springer) e Association for Computing Machinery (ACM) com a palavra-chave: Home Automation.

Nesse panorama, no segundo semestre de 2004, imediatamente após a finalização da dissertação de mestrado intitulada Desenvolvimento de um Simulador de Controle de Dispositivos Residenciais Inteligentes: Uma Introdução aos Sistemas Domóticos (BOLZANI, 2004a) e do lançamento do livro Residências Inteligentes (BOLZANI, 2004b), o desenvolvimento de um ambiente computacionalmente ativo, onde existem inúmeros dispositivos eletrônicos conectados, cercando o usuário e interagindo com ele a todo instante (WEISER, 1993), era um objetivo apropriado e natural para dar continuidade aos estudos e testar no mundo real os resultados encontrados no simulador, construído no mestrado.

No entanto, observando o trabalho de outros autores e o histórico das residências inteligentes, o desenvolvimento de um sistema de controle residencial utilizando abordagens tradicionais, focadas exclusivamente em aspectos técnicos, não traria uma contribuição significativa. $\mathrm{O}$ fato é que, mesmo sendo considerados promissores, esses sistemas nunca foram adotados amplamente. Isso sempre intrigou os pesquisadores, uma vez que as casas automatizadas sempre despertaram o interesse das pessoas.

Para o doutorado, uma nova abordagem deveria ser utilizada, considerando as sutilezas das interações dos moradores e de suas rotinas domésticas para o desenvolvimento de sistemas residenciais.

Uma revisão inicial das referências apontou uma forte ligação dos ambientes inteligentes com a Computação Ubíqua. E naquele momento, uma rede de sensores sem fio (para sentir e manipular o ambiente por meio de sensores e atuadores), uma plataforma de desenvolvimento (para gerenciar todos os dados) e uma interface gráfica eram necessárias para iniciar todo processo de criação do ambiente.

No segundo semestre de 2005, havia diversos modelos de redes sem fio no mercado e o protocolo ZigBee estava se destacando como o mais apropriado para a automação residencial. Devido ao alto custo do kit de desenvolvimento, a alternativa foi comprar o chip do rádio IEEE 802.15.4, montar o nó de controle e desenvolver o protocolo de roteamento de pacotes. A primeira versão funcional com transmissão ponto a ponto (sem roteamento de pacotes) ficou pronta nos primeiros meses de 2006. A Figura 2 ilustra o nó de controle com fonte de alimentação, rádio, microprocessador, antena e portas de entrada e saída. 


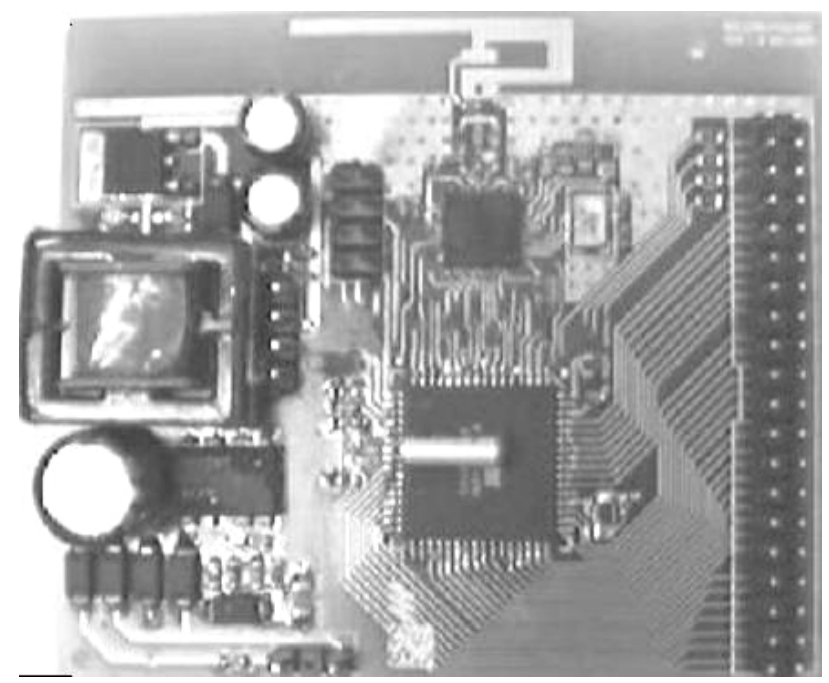

Figura 2: Nó de controle IEEE 802.15.4

Durante o ano de 2006, os nós de controle serviram como plataforma para o desenvolvimento do protocolo de roteamento multiponto. Esse trabalho teve a colaboração dos alunos Renato Arakaki, Fernando Koch e Sidney Chan do curso de Engenharia Elétrica, ênfase em Automação e Controle da Escola Politécnica da Universidade de São Paulo, que realizaram o projeto de formatura sobre o tema.

Foram estudados os seguintes protocolos:

- OLSR (Optimized Link-State Routing protocol)

- DD (Directed Diffusion)

- LEACH (Low Energy Adaptive Clustering Hierarchy)

- AODV (Ad hoc On-demand Distance Vector)

Em resumo, verificou-se que o protocolo DD não é apropriado para automação residencial, uma vez que a sua alta redundância elevaria muito o custo do projeto. O LEACH, apesar da escalabilidade, apresenta algumas limitações como o tempo de resposta, além de necessitar de uma topologia fixa. Protocolos reativos como o AODV reduzem a complexidade da rede, mas assim como o LEACH, são limitados pelo tempo de resposta. O protocolo OLSR foi desenvolvido para redes ad hoc móveis e é orientado a tabelas e pró-ativo na manutenção e detecção de rotas. Em outras palavras, ele troca regularmente informações sobre a topologia da rede com outros nós e tem a vantagem de possuir rotas disponíveis imediatamente quando necessário devido a sua natureza pró-ativa. A escolha então foi por um protocolo ad hoc ativo, uma adaptação do LEACH com o OLSR. 
No fim de 2006, já era possível transmitir e rotear pacotes pela rede sem fio. A Figura 3 ilustra o diagrama geral do sistema.

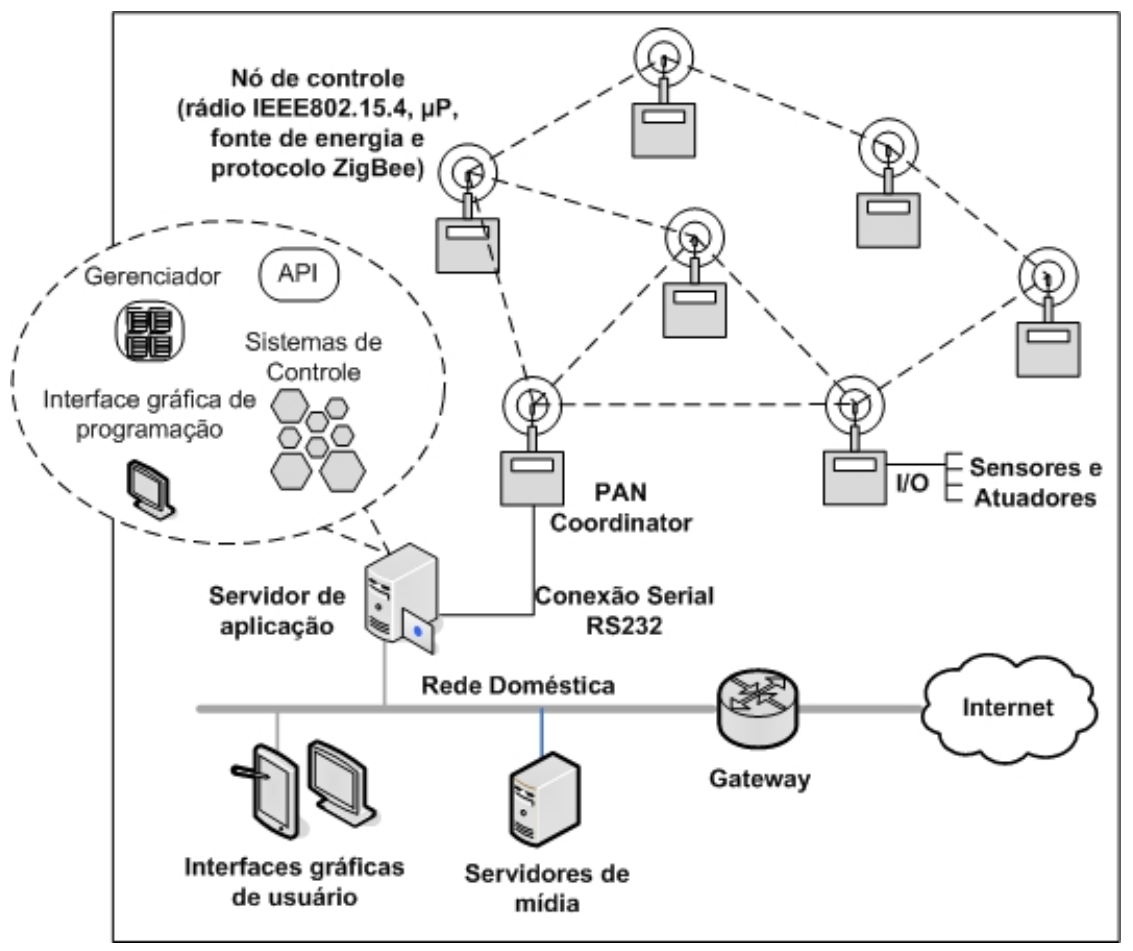

Figura 3: Diagrama geral do sistema desenvolvido.

Em 2007, o suporte oferecido para a criação do Laboratório de Automação Residencial possibilitou a aquisição de uma plataforma de desenvolvimento ZigBee da Texas Instruments. As novas ferramentas de programação e a possibilidade de utilizar o protocolo ZigBee compensaram o tempo gasto na adaptação das aplicações feitas para os nós antigos. Durante esse ano, foi possível desenvolver uma plataforma de software, hardware e firmware capaz de receber dados de sensores, detectar eventos, analisá-los, gerenciá-los e iniciar ações, alterando o ambiente por meio da mudança do estado dos atuadores. Todo esse processo poderia ser verificado por meio da interface gráfica. No fim de 2007, essa plataforma, desenvolvida em Java e utilizando o protocolo ZigBee, estava operacional.

No ano de 2008, as pesquisas sobre ambientes inteligentes foram retomadas porque o entendimento dos conceitos de rotinas, orientação a contexto, análise temporal e espacial dos eventos, e planejamento se tornou necessário. Evidenciou-se a necessidade da criação de uma interface de programa que disponibilizasse uma biblioteca de métodos e procedimentos que suportassem a requisição dos sistemas de controle e de outros programas externos. Essa interface de programa (API - do inglês Application Programming Interface), finalizada no início de 2009, permite que novos módulos sejam desenvolvidos por terceiros contribuindo para a escalabilidade da plataforma e facilitando o processo de testes. 
Por fim, cabe ressaltar que o desenvolvimento do trabalho até o momento permitiu a publicação de trabalhos científicos, que seguem:

- BOLZANI, C. A. M. e NETTO, M. L. The Engineering of Micro Agents in Smart Environments. International Journal of Knowledge-based and Intelligent Engineering Systems, Vol. 13, Issue 1, pp. 31-38, jan, 2009.

- BOLZANI, C. A. M. Brazilian Home Automation in a Glance, HomeToys Home Technology eMagazine, Vol. 12, Issue 3, June/July, 2007.

- BolZANi, C. A. M. Desmistificando a Domótica, Revista do Centro Federal de Educação Tecnológica, Brasil, Vol.8, N.1, ISSN 1677-499X, 2007.

- Bolzani, C. A. M., MOnTAGnOli, C. J. e NeTto, M. L. Domotics Over IEeE 802.15.4 - A Spread Spectrum Home Automation Application, Spread Spectrum Techniques and Applications, 2006 IEEE Ninth International Symposium on, Brasil, pp. 396400, 2006.

- BOLZANI, C. A. M. e NETTO, M. L. Utilização de Algoritmos Genéticos na Criação de Usuários Ativos para o Simulador de Controle de Dispositivos Residenciais Inteligentes - Home Sapiens, VII Simpósio Brasileiro de Automação Inteligente, Brasil, 2005. 


\section{Residências Inteligentes}

\subsection{Introdução}

A introdução da eletricidade foi um marco importante na história das residências. Ela não só transformou o modo como elas são iluminadas, mas também permitiu o desenvolvimento de novas tecnologias capazes de alterar o modo como vivemos. A iluminação elétrica, controlada independentemente em cada cômodo, estendeu o período noturno modificando os hábitos das pessoas e o ciclo de vida das famílias. Além do aumento do conforto, essa forma mais limpa de energia elevou os níveis de higiene tanto por substituir a queima do gás, da parafina e do carvão dentro das residências como também por permitir o desenvolvimento de equipamentos e técnicas mais eficientes de limpeza e higienização.

Com a eletricidade surgiram também novas formas de entretenimento. Os imensos aparelhos de rádio, além de fazerem parte da mobília, eram ponto de encontro onde as famílias se reuniam nos momentos de descontração. As tomadas tinham, e de certa forma ainda têm, uma função social na casa. A localização delas normalmente determina a posição dos eletroeletrônicos e, indiretamente, subdivide os cômodos em regiões funcionais. Antigamente, as tomadas determinavam o posicionamento do rádio na sala de estar. $\mathrm{O}$ mesmo tem acontecido nas últimas décadas com a TV.

Outra transformação aconteceu graças ao telefone. Por muitos anos o aparelho de telefone perdurou único, preso aos fios que vinham da parede. Para atender uma ligação, era necessário correr ao seu encontro. A evolução permitiu que as inúmeras extensões telefônicas cabeadas por toda a casa fossem substituídas por aparelhos sem fio com múltiplos serviços como identificação de chamada e teleconferência. Atualmente, a voz não é a única a trafegar pela linha telefônica. Na verdade, desde a década de 1970, o fax já utilizava o par trançado telefônico para transferir documentos alterando de forma significativa as transações comerciais e auxiliando o trabalho em casa.

Tipicamente, a forma como se agregam serviços e equipamentos eletrônicos às casas pouco se alterou. Cada um dos serviços mencionados acima é regido por diferentes modelos de negócios. Os equipamentos são instalados com pouca ou nenhuma interação com os demais e não usufruem de uma infraestrutura comum. 
A pesquisa sobre casas inteligentes se faz necessária a fim de proporcionar esses e outros serviços de uma maneira mais eficiente, integrada e flexível. O estabelecimento de novos padrões e métricas visa contribuir para a criação de produtos e serviços que auxiliem os moradores em suas rotinas diárias e tragam mais conforto e segurança ao ambiente residencial.

Historicamente, as primeiras insinuações de casa inteligente associavam o conforto do lar com a eletricidade cuidando de todos os afazeres domésticos. Acreditava-se que na casa do futuro, o toque de um botão eliminaria o maior temor que afligia as donas de casa, as tarefas domésticas (BUCHER, 1939). As primeiras formas de controle residencial surgiram nos meados do século XX das mãos de aficionados por eletricidade, como, por exemplo, a casa de Jack Fletcher em 1954 (STIMSON, 1954). Na década de 1970, algumas empresas se dedicaram à produção de equipamentos com funções básicas de automação residencial como controle de iluminação e temperatura ambiente.

Mas controlar remotamente as funções básicas de uma residência parece nunca ter atraído a atenção da grande maioria dos consumidores. Os eletrodomésticos utilitários têm cumprido suas funções apropriadamente auxiliando nas tarefas domésticas e com poucas mudanças substanciais se comparados às suas versões mais antigas. Não houve um equipamento, serviço ou aplicação de controle residencial que realmente tivesse despertado o mesmo interesse ou alterado a rotina das pessoas como, por exemplo, o rádio e a TV.

A sociedade e todo o contexto socioeconômico do século XX não elegeram a automação residencial uma necessidade, e o sonho da casa controlada sob o toque de um botão foi adiado década após década. Além da falta de um serviço ou equipamento imprescindível, a tecnologia esbarrou na ineficiência de se criar uma estrutura convergente. Há vários anos a indústria tem mobilizado esforços na tentativa de estabelecer um padrão de fato de rede doméstica e um protocolo para troca de mensagens entre eletroeletrônicos em uma residência. Segundo Abowd e Sterbenz (2000), ainda não existe um consenso se essa padronização trará benefícios em curto prazo. Alguns acreditam que ela é importante para o crescimento do mercado, outros acreditam que pode atrapalhar o desenvolvimento de novas iniciativas.

A história tem revelado que tão importante é a descoberta de novas tecnologias quanto as aplicações que impulsionam sua utilização. Segundo Melosi (1990), no fim da década de 1870, a lâmpada comercialmente viável inventada por Thomas Edison impulsionou todo o mercado de equipamentos elétricos. A implantação de infraestrutura para iluminação abriu as portas para a criação de novos serviços e muitas outras aplicações.

A história se repetiu, no fim da década de 1980, quando Tim Berners-Lee criou a World Wide Web (WWW), a primeira versão das páginas da Internet que conhecemos atualmente. 
Berners-Lee não inventou a Internet nem o protocolo TCP/IP como ele mesmo menciona em seu site (BERNERS-LEE, 2009). Mas assim como a lâmpada de Edison, a WWW tornou toda a infraestrutura da Internet viável comercialmente e possibilitou a criação de inúmeras outras aplicações. De um lado, o usuário final não é diretamente influenciado pelo tipo de rede ou protocolo utilizado, ele apenas quer contatar seus amigos, ter acesso a músicas ou fazer pesquisas na grande rede. Do outro, a infraestrutura sofreu grandes modificações e avanços para suportar o vertiginoso crescimento do tráfego de mensagens e o aparecimento de novas aplicações como o transporte de voz e vídeo, por exemplo.

No caso das casas inteligentes, vários fatores socioeconômicos do início do século XXI têm despertado o interesse por pesquisas sobre o complexo ambiente residencial e sua relação com seus ocupantes. A preocupação com o meio ambiente, a busca por métodos mais eficientes de uso de energia e recursos naturais, o envelhecimento da população mundial e a desigualdade de renda podem se tornar cenários promissores para o surgimento de aplicações que viabilizem e impulsionem o mercado de redes domésticas e de sistemas de controle residenciais.

Apesar de os protocolos de interligação em rede e da miniaturização dos dispositivos eletrônicos serem elementos importantes para a popularização e viabilidade dos equipamentos de controle residenciais, uma aplicação imprescindível, que auxilie as pessoas em suas rotinas trazendo conforto e segurança para suas famílias, em seus lares, é que de fato impulsionará a tecnologia doméstica assim como fez a lâmpada de Edison ou a WWW de Tim Berners-Lee.

\subsection{Taxonomia}

Smart Home é mundialmente o termo mais popular referente a todo o contexto de automação residencial e residências inteligentes. A palavra esperta, uma tradução direta da palavra inglesa smart para o português do Brasil, além de não demonstrar as qualidades e os benefícios de uma casa automatizada ainda apresenta um caráter depreciativo.

Ao longo dos anos os termos automação residencial, residências inteligentes, domótica, casas do futuro, entre outros têm sido banalizados ou erroneamente utilizados como sinônimos. O uso indiscriminado desses nomes tem levado alguns autores a utilizarem os adjetivos integrado, interativo, colaborativo e até onisciente para enaltecer e diferenciar seus projetos. Em um primeiro momento, essa multiplicidade de nomes e termos parece descrever uma área de pesquisa com várias especialidades bem definidas, mas na verdade esconde um estado de confusão e ambigüidades.

Isso ocorre porque tem sido uma tarefa difícil definir critérios que distinguem uma residên- 
cia inteligente das demais. Mas essa dificuldade em estabelecer um método de classificação não ocorre apenas nos sistemas residenciais. Por exemplo, Carlini (1988) determina cinco níveis de inteligência para sistemas prediais. O nível 0 não apresenta nenhuma forma computadorizada de controle e o nível 4, o nível máximo que ele chama de "Einstein", inclui banda larga para videoconferências e um "sofisticado sistema de automação de escritórios", termo que pouco revela a qualidade e a quantidade de serviços disponíveis.

Como avaliar a qualidade de uma interface homem-máquina? Como medir os benefícios que um dispositivo inteligente oferece aos moradores? Aldrich (2003) e Pilich (2004) sugerem métodos de classificação de residências que consideram diversos níveis de controle, comunicação entre os dispositivos, capacidade de aprendizado e se elas detêm algum nível de ciência das atividades de seus moradores. Nota-se, no entanto, que não há a intenção de se criar rígidas fronteiras entre um ou outro modelo de residência, pois a presença ou não de certa tecnologia - um dos principais fatores usados como critério de distinção - não necessariamente reflete em melhores serviços ou benefícios para o morador. Esse método de classificação é interessante para mostrar a evolução dos sistemas domésticos. Ele ajuda a identificar áreas que carecem de desenvolvimento e pode também revelar oportunidades e negócios inexplorados.

O mercado imobiliário é um dos setores que mais se beneficiariam com a possibilidade de classificar imóveis de acordo com o nível de tecnologia empregado. Os proprietários e os construtores devem ser capazes de avaliar o retorno do capital investido em tecnologia para diferenciar seus imóveis dos que não possuem nenhum benefício de automatização e, assim, atrair compradores. Do outro lado da cadeia, os fabricantes de produtos podem melhorar o foco de seus produtos e o marketing associado a eles. Da mesma forma que a localidade do imóvel, a quantidade de vagas de estacionamento e os serviços de segurança são fatores importantes que posicionam o imóvel em uma escala de valores, a presença ou não de tecnologia pode se tornar também um aspecto relevante no processo de decisão.

A classificação exibida na Tabela 1 considera a tecnologia como elemento diferenciador. Mas assim como sugerido por Venkatesh, Kruse e Shih (2003), exibe também elementos outros fatores de comparação mais sutis como as possibilidades de serviços e interações que os moradores podem usufruir em cada situação.

O último nível, o das residências inteligentes, agrega as funcionalidades e as qualidades que se espera que uma casa venha a desempenhar para entrar em sintonia com os novos paradigmas sociais e tecnológicos e com as necessidades ambientais e energéticas do século XXI. Apesar de algumas iniciativas de controle de dispositivos domésticos datarem de meados do século XX, a introdução de conceitos de inteligência artificial na construção de sistemas residenciais é um 


Tipo de Casa Características Elementos

\begin{tabular}{lll}
\hline \hline Eletrificada & $\begin{array}{l}\text { Controle manual e local de ilu- } \\
\text { minação e cargas }\end{array}$ & $\begin{array}{l}\text { Infraestrutura de energia elé- } \\
\text { trica. Eletrodomésticos. }\end{array}$ \\
\hline Automatizada & $\begin{array}{l}\text { Controle automático de ilumina- } \\
\text { ção e cargas (intra residencial) }\end{array}$ & $\begin{array}{l}\text { Eletroeletrônicos programá- } \\
\text { veis. Dispositivos individuais } \\
\text { de controle. }\end{array}$
\end{tabular}
Comandada Controle remoto de iluminação e Infraestrutura de rede domés- cargas (intra residencial). tica. Dispositivos de co- mando remoto. Espaços físi- cos conectados.

Conectada Reação. Controle remoto ex- Rede de acesso. Gateways. terno. Troca de dados remota. Dispositivos externos de controle. Pessoas conectadas. Acesso a serviços e informação. Espaços social, tecnológico e físico conectados.

Inteligente Ação e tomada de decisões baseadas na cooperação para a solução de problemas. Planejamento. Aprendizado. Conhecimento. Orientação ao contexto.

Inteligência Artificial. Dispositivos auto configuráveis e autônomos. Robôs. Substituição do ser humano nas tarefas.

Tabela 1: Classificação de residências quanto ao nível de controle 
fato recente. A conjunção de fatores técnicos como, por exemplo, a evolução da microeletrônica e da tecnologia de redes com a nova cultura digital do século XXI propicia o desenvolvimento e a inserção de dispositivos eletrônicos em um espaço inexplorado como o ambiente residencial.

\subsubsection{Domótica}

A palavra domótica originou-se do latim domus que significa casa. É a ciência moderna de engenharia das instalações em sistemas prediais. A Domótica é uma ciência multidisciplinar que estuda a relação entre o homem e a casa. A imersão de pessoas em ambientes computacionalmente ativos revelou a necessidade do uso de técnicas mais sutis que gerenciassem a complexidade e o dinamismo das interações dos moradores com o ambiente residencial saturado de diminutos dispositivos eletrônicos interligados em rede.

As denominações usadas em outros países - Domótica em espanhol, Domotique em francês e Domotics em inglês - têm perdido popularidade, pois têm gerado confusão e não são consideradas um bom termo para a venda de produtos. Os termos Residências Inteligentes e Ambientes Inteligentes se popularizaram rapidamente, pois têm mais apelo de marketing e, este último, sugere um conceito mais amplo que vai além do contexto de uma residência e abrange praticamente qualquer ocasião de interatividade do homem com o meio.

\subsubsection{Automação Residencial}

A automação residencial é um ramo da automação predial especializada no controle de operações no âmbito doméstico. Ela se utiliza de sistemas de controle para gerenciar equipamentos eletroeletrônicos e eletromecânicos reduzindo a necessidade de intervenção humana. Em geral, coletam-se informações sobre o ambiente por meio de sensores, analisam-se seus parâmetros e tomam-se decisões segundo um programa específico. Essas decisões podem disparar ações que, por sua vez, podem alterar o estado de atuadores que modificarão o ambiente.

A residência inteligente se utiliza da automação residencial para sentir e manipular o ambiente. Mas uma residência não é considerada inteligente apenas porque automatiza o funcionamento de seus dispositivos. O processo de automação e controle é um meio para a criação de serviços e aplicações. É uma condição necessária, mas não suficiente. Segundo Friedewald e Costa (2003), a conexão de dispositivos a uma infraestrutura de comunicação não garante a inovação em si, mas a automação residencial potencializa os recursos de uma casa possibilitando a execução de tarefas associadas ao conforto, segurança, comunicação, conveniência e entretenimento de seus ocupantes. 


\subsubsection{O Termo Inteligente}

A utilização do termo inteligente como diferenciador entre o estado mais simples de uma residência e o seu estado evoluído, ou de valores agregados, requer alguns cuidados. O dicionário Aurélio define inteligência como a "capacidade de aprender, compreender, adaptar-se facilmente, interpretar ou desenvolver alguma forma de intelecto ou perspicácia" (FERREIRA, 1999).

Porém, segundo Norvig e Russel (2002), um sistema não precisa ter um cérebro humano embutido para ser chamado de inteligente:

[...] é mais importante estudar os princípios básicos da inteligência do que reproduzir um exemplar. [...] Os textos de engenharia aeronáutica não definem como objetivo de seu campo criar máquinas que voem exatamente como pombos a ponto de poderem enganar até mesmo outros pombos.

Eles acreditam que essa abordagem elimina um possível conflito entre a Inteligência Artificial (IA) com conceitos definidos pela Ciência Cognitiva. Essa distinção foi benéfica pois permitiu que ambas as ciências se desenvolvessem com mais rapidez e ainda acrescentam:

[...] a Ciência Cognitiva de verdade se baseia necessariamente na investigação experimental de seres humanos ou animais, e supomos que o leitor tenha acesso somente a um computador para realizar experimentação. [...] Se os comportamentos de entrada/saída e sincronização do programa coincidirem com os comportamentos humanos correspondentes, isso será evidência de que alguns dos mecanismos do programa também poderiam estar operando em seres humanos.

Então, o que uma residência deve fazer ou ter para ser chamada de inteligente?

Ainda segundo Norvig e Russel (2002), “a Inteligência Artificial é o estudo de agentes. Um agente é tudo o que pode ser considerado capaz de perceber seu ambiente por meio de sensores e de agir sobre esse ambiente por intermédio de atuadores". Dentre os agentes, aqueles que selecionam uma ação dentre outras que venha a maximizar uma medida de desempenho, combinam em algum grau autonomia, tomada de decisão e inferência, e que seu estado inicial possa ser modificado e ampliado podem ser chamados de inteligentes.

Dessa forma, sob a luz da Inteligência Artificial, no momento que a residência desempenha funções como as desses agentes, acredita-se que ela possa ser adequadamente chamada de inteligente. 


\subsubsection{O Conceito de Residências Inteligentes}

O conceito de residências inteligentes está fundamentalmente atrelado ao uso de tecnologia para melhorar a qualidade de vida das pessoas no ambiente residencial.

Na literatura não existe ainda uma definição concisa e amplamente aceita. Existe, no entanto, um consenso das funções que se espera que uma residência inteligente venha a desempenhar: ela deve ajudar seus habitantes a viverem de forma saudável, feliz e segura; deve executar várias tarefas automaticamente para aliviar o trabalho gerado pelos cuidados rotineiros de uma casa; deve prover um maior nível de autonomia pessoal e vida independente; deve integrar atividades de trabalho, aprendizado e diversão; deve utilizar eficazmente e minimizar o uso de recursos naturais e energéticos; e por fim, não perturbar as pessoas com detalhes tecnológicos de como ela funciona.

Nugent et al. (2008) enfatiza o aumento da qualidade de vida por meio de uma tecnologia envolvente e transparente:

O objetivo de uma casa inteligente é monitorar as atividades de uma pessoa dentro de seu próprio ambiente de vivência e como ela interage com dispositivos domóticos, e baseado nessas interações e na sua atual sequiência de atividades, o ambiente pode ser controlado e adaptado para lhe proporcionar uma melhor experiência em seu dia-a-dia. Esta melhoria de vida pode ser alcançada provendo um maior nível de autonomia pessoal e de vida independente, o aumento da qualidade de vida ou o aumento da sensação de segurança.

Outros autores dão maior ênfase à tecnologia em si:

Uma residência inteligente pode ser definida como um agrupamento dinâmico de componentes interconectados que integram o mundo físico dos usuários e dispositivos com o mundo virtual de serviços e aplicações (CHHETRI; LOKE; KRISHNASWAMY, 2004).

"Um espaço inteligente integra humanos e computação com ambientes físicos." (SATYANARAYANAN, 2001).

Uma casa não é inteligente porque foi bem construída, nem por quão eficaz foram usados seus espaços; nem porque é sustentável, usando energia solar ou reaproveitamento de água, por exemplo. Uma casa inteligente de fato inclui essas coisas, mas o que a torna inteligente são as tecnologias interativas que ela contém (HARPER, 2003).

"Residências inteligentes oferecem, por meio da combinação de seus equipamentos eletrônicos, avançados benefícios a seus ocupantes.” (NORBISRATH et al., 2005). 
Uma casa inteligente pode ser definida como uma residência equipada com tecnologia computacional e de informação que antecipa e responde às necessidades dos ocupantes, trabalhando para promover seu conforto, conveniência, segurança e entretenimento por meio do gerenciamento da tecnologia dentro da casa e conexões com o mundo externo (ALDRICH, 2003).

Mark Weiser, em seu famoso artigo The Computer for the 21st Century, descreveu sua visão de Computação Ubíqua com a "criação de ambientes saturados com capacidades computacionais e de comunicação, graciosamente integrados com usuário humanos.” (WEISER, 1991).

Em 2001, o Information Society Technology Advisory Group (ISTAG), um conselho que define estratégias com relação a questões tecnológicas para a Comissão Européia, elaborou um documento descrevendo alguns cenários de como seriam a vida das pessoas em 2010 (DUCATEL et al., 2001). O objetivo principal foi demonstrar pessoas comuns (e não apenas usuários) sendo beneficiadas com novos serviços e aplicações propiciadas por uma tecnologia onipresente e transparente.

O ISTAG definiu o termo Inteligência de Ambientes (AmI - do inglês Ambient Intelligence) como:

A Inteligência de Ambientes deriva da convergência de três tecnologias chave: Computação Ubíqua, Comunicação Ubíqua e Interfaces Amigáveis com o Usuário. Quando a convergência for alcançada, humanos serão rodeados por interfaces inteligentes sustentadas por tecnologias de computação e de rede embutidas em objetos do dia-a-dia como móveis, roupas, veículos, estradas e materiais inteligentes, mesmo em substâncias decorativas como tinta.

A Inteligência de Ambientes implica um ambiente computacionalmente ativo, avançada tecnologia de redes e interfaces específicas. Ele deve: ser ciente da presença e de características específicas das pessoas, como suas personalidades; se adaptar às necessidades dos usuários; ser capaz de responder de forma inteligente às indicações de desejo, faladas ou gesticuladas; e mesmo resultar em sistemas que são capazes de engajar um diálogo inteligente.

Inteligência de Ambientes deve também ser não intrusiva e sempre invisível e a interação deve ser relaxante e agradável para as pessoas, e não precisar de longos processos de aprendizado.

O texto acima claramente demonstra a dificuldade em se estabelecer uma definição precisa sobre o tema. É notável a forte presença de conceitos mais antigos como a Computação Ubíqua corroborando a visão de Weiser mais de dez anos depois. O conceito de Inteligência de Ambientes do ISTAG vai além do contexto de uma residência e abrange praticamente qualquer ocasião de interatividade do homem com o meio, seja dentro do carro, da casa ou mesmo no ponto de ônibus. 
Apesar desse conceito ser abstrato e pouco útil para definição de um projeto ou plano de negócios, ele carrega uma responsabilidade maior do que simplesmente definir uma série nova de produtos ou protocolos. O ISTAG acredita que a AmI lidere o desenvolvimento tecnológico nos próximos anos e seja uma força política e social, um novo paradigma da Tecnologia da Informação, abrindo inúmeras oportunidades e negócios.

\subsection{As Residências Inteligentes Sob Um Novo Contexto}

Desde o início do século XX, quando surgiram os primeiros eletrodomésticos nos Estados Unidos, os fabricantes já usavam o termo casa do futuro para promover os benefícios que seus equipamentos iriam trazer para a dona de casa na época (HORRIGAN, 1988).

Cem anos depois, o mesmo termo ainda é mote para a venda de eletrodomésticos e continua representando uma situação de facilidades e conforto. Porém, assim como houve dúvidas sobre os benefícios da energia elétrica no começo do século XX, conforme Melosi (1990), hoje a dúvida envolve os benefícios de se conectar cada eletrodoméstico em rede permitindo seu monitoramento e comando à distância.

Referente às casas do futuro, onde se espera que elas exerçam sua própria gestão e que sistemas de automação residencial gerenciem as diversas atividades domésticas, rotineiras e cansativas, trazendo benefícios em termos de conforto e redução de despesas, a questão principal é: quando realmente acontecerão mudanças significativas nas casas.

No entanto, nunca houve uma ocasião tão positiva como a atual para a adoção de novas tecnologias que realmente alterassem de maneira significativa o modo como construímos e usamos as residências. O panorama socioeconômico que leva a mulher e o homem a trabalharem o dia todo, fora de casa, bem como a crise energética e a problemática ambiental são fatores que propiciam a criação de soluções de automação e controle de equipamentos residenciais.

Segundo Nickles (2002), a tecnologia pode contribuir, basicamente, de três formas para auxiliar nossas vidas:

- Ter uma aplicação prática, eliminando tarefas cotidianas ou tornando-as mais simples e rápidas;

- Prover formas de diversão e passatempo;

- Aumentar o status ou prestígio.

No âmbito residencial, pode-se então adicionar: 
- Prover novas formas de ver e perceber o mundo;

- Tornar mais eficiente a utilização de recursos naturais;

- Aumentar o conforto e a segurança.

Dois fatores contribuem para a procura dessa tecnologia e para o crescimento desse mercado: o primeiro é o ambiente residencial, que permanece praticamente inexplorado para a implementação de sistemas de redes e de controle, o outro é o apelo ao novo que aflora desse tema.

\subsubsection{Aspectos Espaciais}

Até a introdução da água encanada e da eletricidade, poucas eram as diferenças funcionais entre os cômodos. As casas eram tratadas como um arranjo de espaços justapostos. Eram os móveis que definiam a função de cada cômodo. No caso da cozinha, por exemplo, eram as bancadas que definiam a função daquele espaço, mas que podiam facilmente ser transportadas para outro lugar. Com os pontos de água e esgoto, as pias e peças sanitárias começaram a ter local definido. Do mesmo modo, as tomadas começaram a determinar o local de eletrodomésticos, estabelecendo funções aos cômodos antes mesmo da casa ser construída.

Friedewald et al. (2005) salientam que uma casa não é uma simples reunião de indivíduos e deve ser analisada com a perspectiva de promover meios para que a família e amigos possam estar juntos e interagindo. No âmbito da tecnologia, a casa não é uma máquina ou um agregado de ferramentas tecnológicas que ajudam seus residentes a transporem os percalços da vida cotidiana. A casa é um espaço de vivência para humanos, um espaço emocionalmente ativo, provido de um contexto sociocultural. Essa perspectiva adiciona elementos complicadores, mas necessários no momento que se deseja desenvolver sistemas inteligentes que atuarão muito próximos aos moradores e que dependerão de uma análise detalhada do contexto residencial para melhorar a qualidade de vida de seus habitantes. Os autores estabelecem a noção de residência virtual como uma extensão da residência física e uma forma para entender a nova dimensão das funções de uma casa. Apesar da nomenclatura escolhida sugerir outras interpretações, esse conceito contribuiria para identificar os limites funcionais dos novos territórios digitais de cada membro de uma residência e também ajudar a definir o que é público e o que é privado no mundo conectado.

Venkatesh, Kruse e Shih (2003) vão além e elevam a residência ao nível de um espaço vivo, que evolui dinamicamente ao longo do tempo. É um local que deve levar em conta todas as 
necessidades de seus ocupantes, sejam elas emocionais, sociais, educacionais e recreacionais. $\mathrm{Na}$ busca por um modelo conceitual, que melhor defina as novas funções incorporadas pela residência, ele a divide em três espaços não mutuamente exclusivos: espaços físico, social e tecnológico.

O espaço físico, em comparação com os outros espaços (social e tecnológico), é o que menos se altera no curso da vida de uma família e é o que mais dificilmente pode ser alterado. O espaço físico é constituído por um conjunto de subespaços (cozinha, banheiro, quarto, etc.) e definido pela sua funcionalidade, pelo seu tamanho e pelo seu posicionamento em relação aos outros subespaços (o banheiro está ao lado do quarto e ambos fazem parte da área íntima da residência).

O espaço tecnológico é especificado pela quantidade de tecnologia relativa ao tamanho do espaço e ao número de habitantes, pelo nível de uso dessa tecnologia para os propósitos familiares e pela sua contribuição na qualidade de vida. $\mathrm{O}$ espaço tecnológico tem recebido adicional importância recentemente, pois, além do computador pessoal e da Internet, é nele que os sistemas de controle residenciais exercem suas funções.

O espaço social é um componente importante da residência porque envolve os moradores e estabelece o contexto da vida familiar, as necessidades, as atividades, o tempo despendido pelos membros em cada atividade e os objetivos da família. O espaço social é o mais complexo dos três, pois envolve elementos dinâmicos e sutis. É onde a família não apenas desempenha suas atividades, mas se conecta e interagem socialmente. O objetivo do estudo do espaço social é revelar nuances que possam beneficiar o desenvolvimento de novos produtos e serviços para o ambiente residencial.

A sobreposição de um espaço no outro depende de como cada família vive suas rotinas diárias, mais especificamente, depende do conceito de vivência. As relações entre esses três espaços, como devem ser coordenados e como a família mantém um balanço na negociação são aspectos relevantes para o desenvolvimento de sistemas residenciais.

Curiosamente, a adição crescente de tecnologia no interior da residência tem desatrelado a função do espaço físico. Ele não restringe mais as aplicações e recursos que podem ser desenvolvidos. Nele, os recursos são livres para serem utilizados da forma e no momento que desejarmos. Os computadores e dispositivos móveis permitem que qualquer cômodo se torne um centro de informação e entretenimento.

O desafio real é entender como as pessoas desfrutam suas vidas e como elas utilizam os espaços em que vivem. As cozinhas, por exemplo, estão evoluindo de simples ambientes onde se preparam alimentos para um local de entretenimento onde os moradores se alimentam, assistem 
TV, falam ao telefone e, às vezes, observam as crianças brincarem. Segundo Shadbolt (2003), esse modelo é conveniente devido às restrições de tempo dos dias atuais. Entendendo como ocorrem essas mudanças no estilo de vida das pessoas pode-se entender como usar melhor a tecnologia para melhorar suas vidas.

A análise das rotinas dos moradores tem revelado argumentos empíricos e considerações importantes para o desenvolvimento de tecnologias residenciais para o modo de vida do mundo atual. Porém, segundo Venkatesh (1990), mesmo com as novas possibilidades tecnológicas e outras antes delas, no essencial, o caráter social do ambiente familiar ainda se mantém. Fato que torna o estudo relevante é a oportunidade para avaliar esse novo confronto entre a família, o computador e os dispositivos móveis, em sua fase inicial, assim como aconteceu com a TV e o telefone décadas atrás.

\section{Desafios}

Desenvolver a nova geração de aplicações e serviços para casas é diferente de desenvolver aplicações e serviços para o setor industrial e comercial. Apesar de cada organização estabelecer seu ritmo diário, em uma indústria e em muitos ramos comerciais, as aplicações são geralmente bem definidas e delineadas em termos de produtividade, eficiência e lucro. Cada indivíduo dispõe de uma série limitada e conhecida de recursos. Seus movimentos são restritos e normalmente monitorados.

No ambiente residencial, os recursos são livres para serem utilizados da forma e no momento que desejarmos. As atividades desenvolvidas ao longo do dia vêm se desacoplando das funções iniciais impostas pelo espaço físico (quarto, sala, área de serviço, etc.). Cada cômodo pode ser, ao mesmo tempo, um centro de informação, comunicação e entretenimento. Kidd, Orr e Abowd (1999) definem as casas como "ambientes de livre escolha", onde não há regras estabelecidas de quando, como ou onde os recursos serão solicitados e utilizados.

As paredes já não delimitam as atividades que um cômodo pode desempenhar. A tecnologia permite que várias atividades ocorram dentro de um cômodo ou ainda que se espalhem pela casa como, por exemplo, sistemas de monitoramento de crianças que criam uma cerca virtual envolvendo vários ambientes. A definição dessas áreas virtuais é extremamente importante porque a residência inteligente utilizará essas informações para sua análise de contexto e contínuo aprimoramento de seus serviços. No entanto, se considerar que os sistemas de rastreamento em ambientes fechados (estereografia, sonar, etc.), assim como qualquer outro conjunto de sensores, estão sujeitos a imprecisões, e que elas podem influenciar diretamente a decisão tomada pelos sistemas de controle de uma residência inteligente, então é de se esperar que tais sistemas 
sejam capazes de lidar com incertezas.

\subsubsection{Aspectos Tecnológicos}

Os indicadores de desempenho da indústria de semicondutores, como a potência computacional, banda de comunicação, capacidade de armazenamento, dissipação de potência e densidade de integração revelam que esses valores alcançaram uma região que permite que eletrônicos possam ser integrados em praticamente qualquer objeto físico como roupas, móveis, carros e casas. A possibilidade de integrar dispositivos eletrônicos a objetos comuns transforma o modo como as pessoas interagem com esses objetos e amplia o uso dos mecanismos de interação do corpo humano com eles e com o ambiente.

Atualmente, algumas iniciativas de controle residencial como as citadas em (HARPER, 2003) utilizam computadores pessoais para gerenciar os demais equipamentos. Porém, esse modelo de computador genérico, de mesa, como conhecemos, com central de processamento, teclado, mouse e monitor, tem sido gradualmente substituído pela visão de Computação Ubíqua proposta por Mark Weiser (WEISER, 1991) e que é um dos pilares do desenvolvimento de residências inteligentes.

A visão é que o computador genérico será distribuído pela casa, do mesmo modo como aconteceu com os motores elétricos no início do século XX, dando lugar a inúmeros dispositivos, com funções bem definidas, com a programação e o conteúdo distribuídos por empresas do mesmo modo que as concessionárias distribuem energia elétrica e gás. Alguns desses dispositivos já existem e desempenham funções que se beneficiam de informações obtidas da Internet em tempo real.

A Computação Ubíqua tenta unir a tecnologia ao modo de vida, na forma de pequenos dispositivos computacionalmente integrados, servindo múltiplos usuários pela casa. Ela é mais apropriada do que o computador monolítico, uma vez que as atividades domésticas são naturalmente espalhadas pela casa, tanto no tempo quanto no espaço (MATEAS et al., 1996).

As novas tecnologias de redes de controle sem fio permitem que se agreguem serviços ao ambiente residencial superando as inconveniências dos sistemas centralizados e cabeados em vários aspectos: (i) ela permite que os equipamentos e funcionalidades sejam adquiridos conforme a necessidade, adaptando-se ao orçamento; (ii) em caso de falhas, elas tendem a ser localizadas e não globais, reduzindo a possibilidade de panes generalizadas; (iii) os nós de controle ficam próximos às cargas, eliminando cabos e o chaveamento à distância de cargas de potência; (iv) o processador do nó de controle tende a reagir mais rapidamente quanto às 
transições de entradas e saídas locais, entre outras.

A tecnologia de interligação de dispositivos em rede alcançou um nível satisfatório na relação entre taxa de transmissão e consumo de energia. Modernas técnicas de construção de circuitos integrados, métodos de transmissão e protocolos de comunicação têm possibilitado o desenvolvimento de aplicações de monitoramento de pessoas e ambientes, abrindo oportunidades na área de pesquisas de sistemas residenciais inteligentes. A radiação eletromagnética poderia ser um fator preocupante, mas a exposição de pessoas à radiação emitida pelos nós de controle está muito abaixo dos limites aceitáveis aprovados pela Comissão Internacional de Proteção contra as Radiações Não-Ionizantes - ICNIRP (International Commission on NonIonizing Radiation Protection). A ICNIRP é uma organização científica, internacional e independente que investiga os perigos que podem ser associados às diferentes formas de radiações não-ionizantes. A ANATEL (Agência Nacional de Telecomunicações Brasileira) adota como padrão os valores do ICNIRP (ANATEL, 1999). A radiação emitida por um nó ZigBee, por exemplo, é 600 vezes menor que a de um telefone celular em uso.

O computador pessoal, a Internet e os telefones celulares são os principais responsáveis pela naturalidade com que as pessoas lidam e conversam sobre tecnologia, utilizando um jargão antes restrito apenas aos engenheiros e analistas de sistemas. Eles têm despertado o interesse das pessoas por novos equipamentos e vêm familiarizando e ajudando no maior entendimento das interfaces, facilitando a entrada de outras tecnologias dentro das residências.

Ainda, graças à Internet, houve grandes avanços nas tecnologias das redes de computadores e maiores índices de integração entre as diversas topologias existentes. Essa integração representou um suporte imprescindível aos diversos dispositivos e acessórios envolvidos na elaboração de um projeto de automação residencial. Com isso, os projetos que até então se destinavam apenas ao controle de aquecimento, ar-condicionado e iluminação, passaram a observar os novos requisitos dos sistemas para telefonia, voz, dados e imagem.

O uso simultâneo e integrado de serviços de monitoramento, comunicação e transporte de dados proporciona inúmeras vantagens. A adição de um novo serviço, por exemplo, não é um processo que se inicia do zero. A infraestrutura comum impõe certas regras, cria padrões e direciona esforços, diminuindo custos e tempo de desenvolvimento e instalação. Todos os envolvidos se beneficiam desse modelo tecnológico e de negócios.

\section{Desafios}

Segundo Heierman et al. (2008), desde o início da era do computador, várias predições extraordinárias têm sido feitas de como os computadores revolucionariam nossas vidas, reali- 
zando tarefas da mesma forma como estamos habituados a fazer e, possivelmente, excedendo a inteligência humana. Mas o que ocorre é que o ambiente residencial tem se mostrado extremamente complexo, seus atributos físicos e de contexto variam no tempo e no espaço. É um lugar recheado de emoções e de interações sutis entre seus moradores. A figura do computador monolítico, com mouse e teclado, não se encaixa na maioria das nossas rotinas domésticas. E, apesar do significativo aumento do poder computacional, eles ainda apresentam uma grande dificuldade em aprender simples tarefas humanas.

O que se nota é que não existe meio termo. As residências pouco têm se beneficiado da inserção gradual de sistemas inteligentes como tem acontecido com os automóveis, por exemplo. A casa deve se comportar como um ser inteligente, deve possuir um grau de autonomia, deve se adaptar às condições variantes e se comunicar com os moradores de uma forma natural. Não é razoável assumir que eles queiram programar o ambiente para ajustar seu comportamento, especialmente se o termo programação implicar programação computacional.

Para muitas pessoas, o gerenciamento de tarefas rotineiras, diminuindo gastos com energia ou mesmo gravar um programa de TV sem complicações já trariam grandes benefícios. Mas os sistemas residenciais não têm sido desenvolvidos dessa maneira. É fato que a automação residencial não está presente na maioria das casas apesar dos grande número de microprocessadores usualmente encontrados nos eletroeletrônicos. O comando remoto e a interligação dos equipamentos em rede parecem não ter oferecido benefícios suficientes que motivassem sua adoção em massa.

O desafio então é desenvolver a tecnologia e criar possibilidades para novas aplicações e serviços que beneficiem a vida das pessoas do século XXI. As redes de sensores e nós de controle deverão se integrar perfeitamente com dispositivos computacionais móveis e a infraestruturas fixas de redes de comunicação. De acordo com Basten et al. (2003), a visão dos ambientes inteligentes requer uma mudança fundamental nos paradigmas de arquitetura de sistemas, modelos de programação e algoritmos existentes.

Arquitetura de Sistemas A arquitetura deve prover meios para tratar da dinâmica e da heterogeneidade de um ambiente computacionalmente ativo. Ela deve ser capaz de explorar o espaço, de se auto configurar e se auto organizar quando se juntar ao sistema. Dessa forma, outras entidades podem descobri-la e usar seus serviços. A capacidade de gerenciar o ciclo de vida de cada uma é crucial porque a natureza aberta e dinâmica de um ambiente inteligente depende de que novas entidades participem e contribuam, e que o espaço também se adapte quando elas saírem ou não apresentarem um funcionamento adequado. 
Interfaces desacoplam o desenvolvimento das aplicações do mundo físico dos sensores e atuadores. Qualquer manipulação direta de hardware ou firmware deve ser evitada. As entidades físicas (sensor, atuador, dispositivos inteligentes) devem estar disponíveis por meio de um serviço básico de software que as representem, fazendo com que a residência seja tratada como uma entidade programável. Esse fato traz inúmeros benefícios como a possibilidade de reconfiguração remota dos equipamentos que reduz a necessidade de intervenção profissional e fomenta o desenvolvimento de serviços e aplicações. Em uma arquitetura orientada ao serviço, todos os dispositivos e aplicações são representados com uma entidade de serviço, de forma que sua entrada, saída ou mudança do ambiente possa ser interpretada e manipulada mais facilmente.

É provável que a arquitetura de sistemas seja modular e extensiva devido à própria natureza descentralizada dos dispositivos. Os desenvolvedores devem ser capazes de escrever novos programas e utilizar os serviços provenientes dos módulos existentes. Para isso, deve-se prover uma interface para que serviços e dispositivos de terceiros se integrem de uma forma consistente. É essencial também disponibilizar uma plataforma de desenvolvimento rápido que dê suporte à criação de protótipos, serviços e aplicações. Essas questões, além de apresentarem as dificuldades técnicas intrínsecas ao desenvolvimento dos sistemas distribuídos, também podem sofrer restrições comerciais uma vez que cada segmento envolve diferentes modelos de negócios.

Espera-se que os sistemas de controle aprendam, ao longo do tempo, a responder às expectativas dos usuários com a mínima demanda de energia possível. Eles devem ser capazes de monitorá-los, de responder ás suas solicitações e de se antecipar às suas necessidades. Outros requisitos incluem a aderência a padrões existentes, a provisão de segurança e privacidade, e um mecanismo para suportar operações concorrentes de centenas de dispositivos.

Redes de Comunicação Todos os dispositivos que compõem a arquitetura de uma residência inteligente dependem diretamente de uma rede de transmissão de dados para operarem. É por meio dessa rede que se estabelece a troca de informações entre esses dispositivos, a leitura dos sensores e o envio de novos estados aos atuadores. De fato, essa rede não é homogênea, nem única.

Ducatel et al. (2001) sugerem que a rede doméstica terá uma infraestrutura heterogênea, fixa e móvel. A diversidade de tipos de tráfego requer a utilização de várias redes interligadas entre si, operando concomitantemente de forma transparente ao usuário, dinamicamente reconfiguráveis e amplamente disponíveis. Muitos autores (e.g. (FUJIEDA et al., 2000), (ISHAK et 
al., 2002), (PAUWELS; SALAH; TAVENARD, 2007)) têm se dedicado exclusivamente à criação, análise e melhoria do desempenho de tais redes. Isso se deve ao fato que a rede doméstica tem desempenhado um papel importante na evolução das residências inteligentes, pois elas são, em grande parte, responsáveis pelo surgimento de novas aplicações e serviços nesse setor.

Elas evoluíram significativamente nos últimos anos. Um dos motivos é que os fabricantes acreditam que, detendo essa tecnologia, eles serão capazes de dominar o mercado das residências inteligentes. Segundo Wolf (2003), esse processo se iniciou com a Internet e irá continuar com as redes de controle. Dentre os diversos tipos, as redes sem fio têm se destacado pela facilidade e rapidez do processo de instalação. Seu custo e velocidade atraem os consumidores que também apreciam o aspecto futurista e de modernidade que elas representam.

O planejamento da rede doméstica envolve a descrição da hierarquia do sistema, o desenvolvimento de uma metodologia para interligar dispositivos em redes heterogêneas por meio de conversores (gateways) e um mecanismo para suportar operações concorrentes de centenas de dispositivos.

Atualmente, existem dezenas de tipos de redes domésticas e protocolos de comunicação, o que não reflete em benefícios diretos para o usuário final. Modelos de negócio e políticas de proteção de mercado diminuem as possibilidades de interoperabilidade entre essas diversas redes. Esse fato tem trazido desconfiança ao consumidor que não sabe em que sistema apostar e se terá, em um futuro breve, novos produtos, assistência técnica e peças de reposição.

Tão importante quanto a interoperabilidade entre as redes domésticas é a interoperabilidade entre serviços. E isso requer conversores que traduzam e adaptem informações de um meio ao outro. Em uma residência inteligente, essas redes heterogêneas devem se auto configurar e se comunicar de forma transparente ao morador. Isso implica uma difícil e, historicamente, conturbada integração entre fabricantes com diferentes tecnologias e modelos de negócios.

Uma importante aplicação para uma residência inteligente é a possibilidade de gerenciála remotamente. O envio e recebimento de informações externas ocorre por meio das redes de acesso. Devido aos enormes investimentos envolvidos, elas são geralmente gerenciadas por grandes empresas que provém vários tipos de serviços como Internet, TV e telefonia na mesma infraestrutura. Além das possíveis limitações técnicas, algumas restrições de uso devido a acordos comerciais ou mesmo a imposições de lei podem impossibilitar o gerenciamento remoto.

Algoritmos Muitos dos dispositivos móveis que compõem uma residência inteligente desenvolvem diferentes ciclos de trabalho para reduzir o consumo de energia. É uma questão de 
balanceamento entre processamento dos dados e comunicação em rede para se obter o máximo aproveitamento da bateria. Algumas técnicas consistem em reduzir a frequência de operação dos microprocessadores ou forçam o dispositivo a permanecer semi-ativo por um tempo. Sendo assim, não se pode assumir que alguns dispositivos móveis estarão sempre disponíveis ou mesmo que estarão operando em sua potência computacional total. Torna-se crítico descobrir quais sensores e atuadores estarão participando e colaborando na execução de um determinado serviço e balancear cada contribuição de informação.

Muitos sistemas inteligentes serão formados por dispositivos interligados em uma estrutura ad hoc. Isso significa que a transmissão de informações e as interações se darão dinamicamente, devido à proximidade e a conectividade entre esses dispositivos. Os algoritmos devem operar assincronamente e ter algum grau de autonomia necessitando o mínimo possível de coordenação centralizada. A utilização de redes de sensores e nós de controle facilita a aquisição e a alteração das propriedades de um ambiente, mas introduz uma série de novos requisitos e problemas. Questões sobre sincronização, reconfiguração em funcionamento, tabelas de roteamento, sequência de eventos, etc. não são triviais em sistemas descentralizados onde cada dispositivo, geralmente, detém apenas parte da informação global e opera com recursos limitados.

Basten et al. (2003) sugerem o desenvolvimento de algoritmos que se adaptem a esses ambientes de disponibilidade variada e possam prover uma ampla gama de respostas, quantitativas ou qualitativas, com diferentes graus de fidelidade. Para isso deve-se tentar alcançar um equilíbrio entre a carga computacional e a complexidade na elaboração desses algoritmos para analisar estatisticamente as incertezas, mantendo um nível apropriado de informações sobre o ambiente mesmo em condições críticas. Em outra abordagem apresentada em (BOLZANI; NETTO, 2009), dependendo das características da aplicação, o sistema de gerenciamento analisa a dinâmica do fenômeno físico ou as requisições do usuário e seleciona os algoritmos apropriados para prover respostas satisfatórias, mesmo sob circunstâncias restritas.

Em uma residência inteligente, cujo arranjo pode ser alterado a qualquer momento, a infraestrutura de software deve ser capaz de se adaptar dinamicamente à adição e exclusão de dispositivos, definir prioridades, resolver conflitos e estabelecer modos de cooperação sem que haja a necessidade de perturbar o usuário com problemas técnicos. Em uma sala de estar, por exemplo, dezenas de equipamentos de diversos fabricantes devem coexistir harmoniosamente demonstrando a necessidade de uma capacidade de auto-organização nas infraestruturas de hardware e software. 
Modelos de Programação Cada dispositivo apresenta uma série de serviços dedicados que podem ser utilizados em suas formas simples ou aproveitados na composição de outros serviços com funções agregadas para auxiliarem no gerenciamento das rotinas domésticas. Por exemplo, o sistema de ventilação pode se beneficiar da informação de temperatura de um cômodo disponibilizada diretamente por um sensor ou por meio da análise conjunta da temperatura, luminosidade, umidade relativa do ar e número de pessoas que estão numa determinada área. Esse conjunto geraria uma representação mais fiel do ambiente, poderiam ser unificadas em um possível índice de conforto térmico, e permitiriam uma atuação mais eficaz do sistema de ventilação.

Essas informações são diretamente dependentes das propriedades físicas de cada dispositivo, da sua programação interna, das configurações, das condições e local de instalação, etc. Mas, também, sua integração e gerenciamento têm requerido um alto nível de esforços no desenvolvimento de programas computacionais. O sucesso das tecnologias de residências inteligentes depende diretamente da qualidade desses programas. São eles os responsáveis em maximizar a eficiência na utilização de recursos e em melhorar a qualidade de vida dos moradores disponibilizando serviços cada vez mais customizados para atenderem às suas necessidades e também se adequarem às mudanças da família. A aceitação dos moradores em conviver tão próximos com inúmeros dispositivos eletroeletrônicos, dentro de seus lares, 24 horas por dia, dependerá primeiramente dos benefícios que essas tecnologias poderão trazer e da sua facilidade de manuseio.

A tarefa de programação é uma atividade que pode estar além das capacidades e dos interesses dos habitantes de uma casa. Há algumas décadas, o ajuste de temperatura de um termostato ou a programação dos videocassetes eram operações complicadas para a maioria dos usuários. Atualmente, o problema ainda se mantém, pois o ajuste do home theater envolve conhecimentos detalhados de algoritmos de compactação de áudio e vídeo.

A alternativa de contratar profissionais para programar, atualizar e ajustar os sistemas tem um custo alto, além de ser inconveniente. Segundo Mozer (1998), um dos motivos que a automação residencial não está amplamente disponível e aceita é devido a esse problema de programação. Uma alternativa seria uma casa que se programa sozinha, observando o modo de vida dos habitantes e seus desejos, aprendendo a antecipar e acomodar suas necessidades.

Para atender esse problema, Basten et al. (2003) sugerem que os modelos de programas sejam capazes de lidar com comportamento e padrões, sintetizando automaticamente códigos uma vez que não existirá um modelo universal que sirva para todas as ocasiões. Esses modelos devem gerenciar operações concorrentes uma vez que a arquitetura de hardware em uma resi- 
dência inteligente será composta por inúmeros dispositivos trabalhando concomitantemente.

O nível de inteligência desses programas deve entender o contexto das ações dos usuários para oferecer-lhes o serviço mais adequado. O ISTAG (2003) utiliza o termo computação emocional para a capacidade de sistemas computacionais de imbuir, modelar e reconhecer emoções para interagir com humanos ou com outros sistemas que possam expressar emoções. Por trás dessa capacidade emocional existem complexos métodos de busca, planejamento de tarefas e operações com semânticas que até alguns anos nunca se imaginaria que iriam compor a arquitetura de sistemas residenciais.

Perspectivas de Desenvolvimento A Computação Ubíqua motivou universidades, empresas privadas e entidades do governo a criarem residências-laboratórios para analisar a rotina diária das pessoas e desenvolver sistemas mais adaptados a ambientes saturados de dispositivos eletrônicos. De certa forma, a própria natureza integrada desses laboratórios ajuda a criar um grupo de pesquisa coeso. No entanto, devido à sua complexidade, sua construção depende de grande quantia de recursos humanos e financeiros.

Quando não há essa possibilidade, a investigação se dá de forma independente e muitos temem que possa haver um desperdício de tempo e de esforços. Segundo Abowd e Sterbenz (2000), duas posições antagônicas dividem os pesquisadores quanto a esse aspecto. Um grupo defende que deve haver um direcionamento da pesquisa em busca de um objetivo comum, e que deva haver um esforço para que os sistemas sejam desenvolvidos de forma a se interconectarem e serem interoperáveis. Outro grupo acredita que não deva haver uma coesão na pesquisa relacionada com residências inteligentes. Muitas idéias podem surgir quando não existe um direcionamento e diversos sistemas interessantes podem ser criados, não necessariamente permitindo sua interconexão com os demais. Deve-se focar em que tipo de informação será trocado para identificar padrões de interoperabilidade.

A própria natureza do ambiente residencial, rica em interações sutis entre os moradores e os sistemas, é propícia para o surgimento de novos métodos e tecnologias, dificultando a criação de grupos de pesquisa coesos. Harper (2003) ressalta que o ambiente doméstico não é um lugar estruturado. Não existe o conceito de planejamento, manutenção e suporte técnico como em uma empresa. A grande variação dos perfis dos residentes (sob todos os aspectos social, econômico e cultural) cria diversas implicações técnicas devido à necessidade de um alto teor de personalização, tanto das interfaces, como dos sistemas de controle. Outro entrave é a dificuldade no processo de aquisição de informações para alimentar o sistema, pois não é trivial monitorar e estudar as inúmeras variáveis que envolvem o dia a dia de uma família. 


\subsubsection{Aspectos Sociais}

Quando se analisam as principais tendências que impulsionam o uso de tecnologias em ambientes residenciais observa-se que muitos dos fatores não estão diretamente ligados ao ambiente residencial em si, são fatores externos, de caráter social, econômico e geopolítico, mas que alteram diretamente a rotina diária e as funções exigidas de uma casa.

O ritmo intenso da vida cotidiana no século XXI tem requisitado um aumento da demanda na eficiência e na flexibilidade das rotinas diárias. A casa evoluiu de uma condição de abrigo para um local de conectividade social devido à quebra da relação entre tempo e espaço oferecida por sistemas de tele presença como a telefonia e a Internet (VENKATESH; KRUSE; SHIH, 2003). Cada vez mais as pessoas vêm trabalhando e gerenciando serviços de suas casas. Paradoxalmente, aumenta a necessidade de um lugar como lar, para relaxamento, uma vez que a casa exerce funções além das necessidades básicas de um local de privacidade e descanso.

Segundo Friedewald et al. (2005), o próprio modo de vida adotado pelos jovens dos centros urbanos ou mesmo a busca por novas experiências no mundo digital tem aumentado a procura por equipamentos de entretenimento residenciais. Em um estudo sobre a influência do mundo digital na vida das crianças americanas, mais precisamente as californianas, Venkatesh, Behairy e Chen (2002) descobriram que, devido ao computador e à Internet, elas vêem menos televisão, reduziram o tempo de leitura e passam mais tempo sozinhos, sem tanto contato com família. A Internet alterou a rotina dessas crianças, no tempo e no espaço. A disponibilidade de conteúdo multimídia na Internet permite que vejam os programas favoritos sem depender do horário rígido da TV. Elas têm acesso a bibliotecas inteiras na rede e podem digitar seu trabalho escolar na hora que melhor lhes convier. Estão em contato constante com familiares e amigos por meio de programas de e-mail e de mensagens instantâneas. Tudo isso ao mesmo tempo em que procuram por músicas e vêem fotos dos artistas preferidos. Para esses autores, a Internet é uma alternativa conveniente de convívio social. Ela acaba sendo um novo canal, mais dinâmico e interativo que o telefone e a TV, para as crianças que passam o dia sem a presença dos pais e cada vez mais com a companhia dos avôs ou de terceiros.

Considere-se uma situação hipotética em que um casal, que passa o dia longe de casa em extensas rotinas de trabalho, é responsável pelo sustento e cuidado dos filhos e dos pais. É possível considerar várias formas que os sistemas residenciais inteligentes podem ampliar e melhorar a experiência de todos os moradores. São serviços que historicamente estiveram além do alcance do ambiente residencial.

No caso dos idosos e pessoas com deficiência, os sistemas residenciais inteligentes oferecem mecanismos para aumentar sua autonomia e continuar a desempenhar papéis importantes 
na sociedade. Esses sistemas permitem não apenas monitorar remotamente o estado de saúde (funções vitais e necessidades diversas), mas também compensar deficiências funcionais (controle remoto de dispositivos e portas), prover segurança (alarmes de incêndio e de intrusão enviados ao tomador de conta, mecanismos automáticos de proteções para equipamentos como fogões e ferro de passar roupa) e facilitar o acesso aos meios de comunicação. Para as crianças, oferecem mecanismos de emancipação por meio do acesso à informação e entretenimento. $\mathrm{O}$ casal se beneficia com as ferramentas de monitoramento em tempo real do que acontece dentro da casa e com a possibilidade de controle de dispositivos à distância.

\section{Desafios}

Contexto Socioeconômico Comparadas a outros setores, como o automobilístico, por exemplo, as casas pouco se desenvolveram no último século. Segundo Glancey (2008), na década de 1960, os opcionais para carros já incluíam lavadores de pára-brisas, aquecedores e rádios. Atualmente, em um modelo médio pode-se encontrar controle climático individualizado, tocadores de mp3, travas com acionamento remoto, vidros e teto solar elétricos, computador de bordo, luzes internas de intensidade variável, alarme de segurança, bancos com ajuste elétrico, dentre outros. Casas modernas raramente possuem todo esse conforto, mesmo custando várias vezes mais do que o automóvel da família.

A teoria do consumo visível abordada em Charles, Hurst e Roussanov (2007) pode estar por trás dessa desigualdade:

Um indivíduo tende a gastar parte maior de sua renda pessoal em bens visíveis quando a renda média de seu grupo é mais baixa. O motivo é a emulação de um nível superior de status - o estímulo de uma comparação baseada na inveja, que nos leva a tentar superar aquilo que fazem as pessoas junto das quais temos o hábito de nos classificar.

Automóveis, roupas e jóias são exemplos de consumo visível. Para compensar a diferença, gasta-se menos em educação, saúde, entretenimento e com equipamento e mobília em suas casas. Os autores demonstram que essas diferenças existem praticamente entre todas as subpopulações, que são de certa forma constantes no tempo e apresentam valores economicamente significativos.

O tempo realmente parece não ter influenciado muito essa questão. Em A Teoria dos Sentimentos Morais, Adam Smith reconheceu que as pessoas valorizam a riqueza não só pelos bens e serviços que lhes permite adquirir, mas também pela impressão de que ela causa sobre as outras (SMITH, 1759). 
Em 1899, Thorstein Veblen, sociólogo e economista, argumentou que as pessoas gastavam de maneira desmedida em bens visíveis de modo a provar que eram prósperas. Ele chamou esse movimento de consumo conspícuo (VEBLEN, 2008).

Porém o que Smith e Veblen não sabiam é que o consumo conspícuo não é um fenômeno universal de fato. É uma fase de desenvolvimento. Segundo Charles, Hurst e Roussanov (2007), essa tendência declina à medida que países, regiões ou grupos específicos enriquecem. Quanto mais rica uma sociedade ou um grupo social, menos importantes se tornam os gastos visíveis. Em determinado momento, o luxo se torna menos uma ferramenta de competição por status público e mais uma forma de obtenção de prazer pessoal.

Prince e Schiff (2008) descrevem padrão semelhante no livro The Middle-Class Millionaire (O Milionário de Classe Média) que analisa os hábitos de consumo dos 8.4 milhões de domicílios norte-americanos que construíram sua riqueza sem a ajuda de heranças, abrigando famílias cujo patrimônio total, incluindo o valor dos imóveis, fica entre um milhão e dez milhões de dólares. Além da inclinação por carros exóticos, esses milionários investem em atendimento de saúde de alto padrão, reformas de casas e toda forma de instrução pessoal.

Para os consumidores conspícuos, o interior da casa é o lugar menos visível e sujeito aos menores volumes de investimentos. Para a nova alta classe, o lado pirotécnico da automação residencial também fica em segundo plano. Nesses dois contextos, como estimular o mercado de residências inteligentes se os produtos estão a cada dia menos visíveis? Se o apelo da Computação Ubíqua é justamente fundir a tecnologia aos ambientes residenciais?

É provável que as formas de distinção social nunca deixem de ser inventadas e o marketing associado aos produtos tecnológicos se beneficia da divisão em classes. Outro aspecto, e talvez o mais importante, seja o uso da tecnologia, onipresente e invisível, para dar suporte a novos serviços que atendam às necessidades das pessoas desse novo século.

Privacidade e Segurança Muitos dos serviços disponibilizados em uma residência inteligente se baseiam em informações provenientes de sensores que monitoram constantemente diversos aspectos dos ambientes e das pessoas. Parte dessas informações que circulam pela rede doméstica é disponibilizada e enviada remotamente via rede de acesso para empresas que prestam serviços como, por exemplo, homecare ou gerenciamento remoto de gás, eletricidade, água, etc. $\mathrm{O}$ vazamento e o uso indevido dessas informações podem colocar em risco a privacidade e a segurança dos moradores de uma residência inteligente.

Venkatesh (2003) descreve uma grande quantidade de informação que é disponibilizada numa simples transação caso uma geladeira esteja apta a identificar a falta de alimentos e soli- 
citar a compra de comida pela Internet. Essas questões de privacidade e segurança envolvem o quanto se está disposto a compartilhar informações privilegiadas com terceiros em troca de benefícios como conforto e comodidade. Quando usamos o cartão de crédito ou o telefone celular já estamos compartilhando a informação do que consumimos, dos lugares por onde passamos e com quem conversamos. É um monitoramento bem mais sutil que as câmeras do Big Brother no clássico de George Orwell, 1984, e mais elegante também, pois acontece com o nosso consentimento.

Outro problema é definir quais são os limites dos espaços públicos e privados de um cidadão. Segundo o ISTAG (2003), o aspecto físico da residência é um conceito já desenvolvido e reconhecido amplamente, em termos legais, sociais, econômicos e tecnológicos. Em contraste com o mundo real, no mundo virtual existem poucos indicativos legais e sociais que constituem um espaço privado e protegido, do espaço aberto e público.

Confiança e Aceitação Alguns autores demonstram certo nível de ceticismo quanto à ampla adoção de tecnologia no ambiente residencial. Segundo Friedewald e Costa (2003), vários fatores devem ser levados em consideração:

- Nem tudo que é tecnologicamente possível e disponível é aceito;

- As pessoas precisam ser capazes de adquirir tecnologia (dinheiro, tempo, atitude, etc.);

- A tecnologia pode ser usada de forma diferente da proposta pelos fabricantes (Internet, SMS);

- As pessoas podem adquirir tecnologia e não usá-la;

- A tecnologia só estará disponível se for lucrativa aos fabricantes;

- Os consumidores podem usar a tecnologia, mas não ter confiança nela.

Além desses fatores, Harper (2003) lista as principais razões para o mercado de automação residencial não ter evoluído:

- Falta de motivação para aumentar a produtividade no trabalho doméstico;

- Pouco envolvimento dos usuários no processo de desenvolvimento das tecnologias;

- A visão dos fabricantes de que a tecnologia doméstica não é excitante;

- O constante foco em equipamentos que funcionam isoladamente; 
- Pouca atenção dada à usabilidade dos produtos e aos usuários.

Outros fatores sociais como as regras de convivência familiares também criam implicações para se projetar equipamentos de uso residencial. Um exemplo interessante é mencionado em Frohlich e Kraut (2003). Eles enfatizam que o uso residencial do computador e da Internet não depende apenas da funcionalidade dos programas e serviços. Depende também do modo como o computador é compartilhado entre os membros da família, quem pode se conectar à Internet, em que momento e por quanto tempo.

\subsubsection{Aspectos Ambientais}

No Reino Unido, segundo Green e Marvin (1994), cerca de 50\% das emissões de $\mathrm{CO}_{2}$ são associadas ao aquecimento de ambientes, $22 \%$ ao aquecimento de água e $25 \%$ aos eletroeletrônicos. Nos Estados Unidos, residências e comércios são responsáveis por 39\% do consumo total de energia que inclui eletricidade, petróleo e seus derivados, carvão, gás natural e fontes renováveis (EIA, 2009).

Dentre as sugestões apresentadas por Green e Marvin (1994), como a ampla utilização de isolamento térmico e o uso de fontes de energia menos poluidoras, eles enfatizam que dezenas de milhões de toneladas de $\mathrm{CO}_{2}$ poderiam deixar de ser emitidas na atmosfera se a eletricidade fosse utilizada de forma mais eficiente, uma vez que, particularmente nestes dois países acima citados, grande parte da produção de energia elétrica vem por meio da queima do carvão. Além da melhoria da tecnologia de materiais e processos na construção de eletroeletrônicos (que não está no escopo deste trabalho), a arquitetura proposta pode ser utilizada como uma importante ferramenta de monitoramento constante e conseqüente aumento da eficiência na utilização desse recurso.

\section{Aplicações}

Gerenciamento de Energia Elétrica Pelo Lado da Demanda O Gerenciamento pelo Lado da Demanda, GLD, (DSM, da sigla em inglês para Demand Side Management) é o conceito de controlar as cargas do lado do consumidor (demanda) para que todo o sistema elétrico opere mais eficientemente. Em outras palavras, o GLD consiste em ações de planejamento, implementação e monitoramento de equipamentos eletroeletrônicos com o intuito de promover mudanças no perfil da curva de carga do sistema e auxiliar os usuários a controlar seus custos com energia.

Historicamente, o gerenciamento pelo lado da demanda tem sido uma iniciativa das concessionárias de energia elétrica, estimulada pela crise do petróleo na década de 1970, e dirigida à 
conservação de energia elétrica, por meio da racionalização do uso e de incentivos ao desenvolvimento de produtos mais eficientes e de menor consumo. Com isso, assegura-se uma redução dos desperdícios, dos custos e também nos investimentos em novas unidades geradoras.

Quando a rede elétrica está sendo muito utilizada, no horário de pico noturno, por exemplo, o custo para as concessionárias para atender à demanda vai ficando progressivamente mais alto devido ao acionamento de usinas geradoras adicionais para manter o fornecimento. Em casos muito críticos, quando a demanda ultrapassa o limite da rede, os sistemas de proteção entram em operação desligando o fornecimento, gerando um blecaute. Essa situação indica que a rede está operando em seu limite e que novas usinas devem ser construídas. A construção de usinas geradoras de energia requer altos investimentos e seus benefícios têm sido questionados frente aos inúmeros problemas ambientais que provoca.

O gerenciamento da demanda em uma residência distribui o acionamento de serviços não prioritários em horários que não coincidam com os horários de pico, permitindo um uso mais eficaz da malha energética, adiando a necessidade por novas fontes adicionais de energia. Para estimular essa prática, além de disponibilizar publicamente as políticas de uso de energia, as concessionárias têm oferecido alguns benefícios a seus clientes. Desde a década de 1970, as concessionárias do Reino Unido têm provido uma redução de tarifas durante o período noturno. A instalação de medidores especiais e de comutadores de cargas permite que o sistema atue automaticamente sem a necessidade de supervisão humana. Esses medidores de energia têm evoluído bastante e permitido o desenvolvimento de vários serviços interessantes como o estabelecimento de um consumo máximo diário ou a utilização de cartões pré-pagos com créditos de energia, similares aos dos celulares.

As residências inteligentes podem se beneficiar dessa redução de tarifas controlando diretamente seus equipamentos por meio da rede doméstica. Boivin (1995) menciona uma economia de $15 \%$ a $20 \%$ no gasto com energia elétrica em projetos pilotos na França. O funcionamento de eletrodomésticos que consomem grande quantidade de energia como secadoras, máquina de lavar roupas e lava louças estaria sujeito ao preço da energia naquele momento. O sistema poderia esperar até o período em que as taxas fossem menores para aumentar a demanda por meio de sequências pré-definidas ou o morador poderia decidir pagar um preço mais alto e usá-los imediatamente.

Além dessas alternativas, é possível haver o controle de bombas em geral, principalmente na irrigação, e dos aquecedores de ambiente, muito comuns em países com clima frio. O aquecimento de água, residencial ou comercial, também estaria sujeito ao controle pelo lado da demanda, uma vez que aquecedores de passagem com resistências elétricas como chuveiros e 
boilers são uma porção significativa da carga de pico.

Uma casa planejada para o gerenciamento de demanda pode reduzir o consumo de energia causando um pequeno impacto no conforto de seus ocupantes. Isso pode ser feito diminuindo um pouco a potência das lâmpadas, setorizando o uso de aquecedores, usando ventilação forçada ao invés de ar-condicionado ou ativando o suprimento de fontes alternativas de energia como a solar, eólica ou a armazenada em baterias. Em uma residência integrada, esses procedimentos podem ser programados para terem curta duração de modo a passarem despercebidos pelos usuários.

Outro fator importante é que o gerenciamento pelo lado da demanda desperta noções de civilidade e evidencia a participação do usuário no processo de aprimoramento do uso de recursos naturais. Mas um dos principais pontos que dificultam a adoção de programas de GLD pelos consumidores é a dificuldade em relacionar o uso da energia com o valor da conta, segundo Gellings e Chamberlin (1993). A medida de consumo de energia em kWh não é um conceito bem claro para a maioria da população. A associação do consumo de um carro, em km/1, com o preço da gasolina é uma situação mais corriqueira. Muitos sabem o preço médio dos combustíveis no posto, mas raramente sabem quanto custa o $\mathrm{kWh}$ ou quais os equipamentos residenciais que consomem grande parte dessa energia.

Gerenciamento de Energia Elétrica Pelo Lado do Provedor As concessionárias de energia, água e gás podem se utilizar de infraestruturas de redes de comunicação para terem acesso às medições de forma remota a fim de analisar o padrão de consumo de cada residência e detectar anormalidades. O gerenciamento remoto também permite executar cortes e religações sem a necessidade da visita do técnico.

\subsubsection{Aspectos de Saúde}

Segundo a Organização das Nações Unidas, a expectativa de vida média da população mundial tem aumentado. As pessoas estão vivendo mais a cada ano que passa. Nos países ricos como Estados Unidos, Canadá e Japão estima-se que em 2050, 32\% das pessoas estarão com mais 60 de idade (em 2006, o índice era de 20\%)(ONU, 2006). No Brasil, cerca de 64 milhões de pessoas terão mais que 60 anos em 2050, 30\% da população do país (IBGE, 2008).

O envelhecimento aumenta a probabilidade de um indivíduo experimentar um declínio da visão, audição, cognição e movimento, restringindo ou até mesmo impedindo a execução das atividades rotineiras. O dicionário Webster (2008) define as atividades da vida diária (ADLs do inglês Activities of Daily Living) como "as atividades básicas que uma pessoa pode realizar 
durante o dia que incluem comer, vestir e banhar". Os profissionais de saúde se referem às ADLs como uma medida da capacidade funcional de um paciente. Para que uma pessoa possa se tornar independente, ela deve ser capaz de realizar essas atividades sem assistência humana. Para alguns idosos, uma simples tarefa como cozinhar um alimento no forno de microondas pode se transformar numa árdua tarefa devido às complexas instruções escritas com letras pequenas nas embalagens dos produtos e às inúmeras formas de seleção de cozimento que os fornos disponibilizam (RUSSO et al., 2004).

Adicionalmente, com o aumento e envelhecimento da população, cresce também o número das pessoas que sofrem doenças crônicas ou com alguma forma de deficiência. De acordo com Brookmeyer et al. (2008), em 2050, quase 100 milhões de pessoas (1.2\% da população mundial em 2050), o quádruplo do número atual, sofrerão do Mal de Alzheimer. E, estima-se que 43\% dos casos necessitarão de um nível alto de cuidados, com monitoramento constante.

A Organização Mundial de Saúde estima que cerca de 6\% da população mundial seja dependente de cuidados diários por apresentar alguma forma de deficiência severa como quadriplegia, paraplegia, cegueira, demência, psicose ativa, entre outras (HARWOOD; SAYER; HIRSCHFELD, 2004).

A combinação de todos esses dados e projeções com os altos custos institucionais de previdência social e saúde é um incentivo para o desenvolvimento de novos serviços de saúde que se beneficiem da atual disponibilidade de recursos tecnológicos.

\section{Aplicações}

Suporte a Portadores do Mal de Alzheimer A tecnologia de residências inteligentes é apropriada ao monitoramento de indivíduos com Alzheimer pois pode se adaptar às suas necessidades, de forma gradativa, de acordo com o avanço da doença. Nos primeiros estágios, quando a falta de memória ainda é leve, a casa monitora suas ações e atua de modo que supra suas falhas sem cercear suas atividades cotidianas e sem prejuízo de sua segurança. Num estágio mais avançado, em que o paciente detém um baixo nível de compreensão do mundo externo e não está mais apto a tomar decisões, a residência altera sua programação para um nível de cerceamento mais elevado com o propósito de manter a segurança do indivíduo e das pessoas que convivem com ele. Nessa situação o ambiente fica menos sujeito às vontades do paciente, elevando o nível de automatização dos serviços e não esperando por sua interação. As informações exibidas nas interfaces são simplificadas e políticas mais restritivas de uso de equipamentos e acesso a locais de risco são adotadas. 


\subsubsection{Aspectos de Mercado}

No fim do século $\mathrm{XX}$, o mercado das residências inteligentes apontava para um caminho de amplo crescimento. A maioria das empresas envolvidas mantinha uma casa equipada com as últimas novidades em automação, comunicação e interfaces para atrair os consumidores da nova era digital.

Porém, a onda de otimismo sucumbiu com o estouro da bolha da Internet no início dos anos 2000. Segundo Scherf (2008), as empresas estreitaram seu foco para algumas poucas aplicações envolvendo comunicação e entretenimento, e o segmento de controle residencial ficou em segundo plano. As companhias que se mantiveram nesse setor direcionaram sua atenção para seus produtos mais comerciais e o conceito da casa completamente gerenciada se esvaiu.

Atualmente, o mercado das residências inteligentes ainda apresenta características de um mercado que não amadureceu: (i) fragmentado em diversos modelos de negócios, (ii) orientado para a tecnologia e não para serviços, e (iii) fortemente dependente de uma aplicação que motive todo o desenvolvimento de uma estrutura comercial e técnica. Esses fatores contribuem para aumentar a relutância por parte dos construtores - e ela se estende a consumidores e aos profissionais envolvidos - em investir capital em uma arquitetura ou produto sem garantias de suporte, continuidade e potencial de lucro.

Segundo o ISTAG (2003), a tecnologia que envolve as residências inteligentes é tão abrangente e complexa que o processo atual de pesquisa, concepção de produto e sua comercialização não serão suficientes para atender às necessidades futuras do mercado. A razão pela qual ela é considerada abrangente é porque tem o potencial de adicionar valor a uma ampla variedade de tecnologias domésticas incorporando nova eletrônica em equipamentos tradicionais. A complexidade reside no fato que o desenvolvimento dessas tecnologias certamente envolve a integração e o esforço de várias cadeias, bem como um engajamento dos pesquisadores da área acadêmica e das empresas.

Um exemplo de integração e colaboração é acertadamente utilizado no IPhone, o smart phone da Apple (APPLE, 2008). Além do aparelho integrar uma alta tecnologia de comunicação com uma interface simples de usar, a um custo acessível, a disponibilidade de uma plataforma de desenvolvimento permite que várias empresas orbitem em volta do aparelho, criando programas, jogos e vários aplicativos que acabam por realimentar o ciclo e beneficiar todos que participam dessa estrutura comercial. Por outro lado, se ele fosse um dispositivo fechado, sem a possibilidade de programação por terceiros, os usuários teriam que esperar pela equipe da Apple para obter novos aplicativos e talvez o sucesso não fosse tão grande. No último quadrimestre de 2008, a Apple já assumia a terceira colocação entre as empresas que fabricam celulares, com 
mais de 4 milhões de aparelhos vendidos no período (COZZA et al., 2008).

Baseando-se no exemplo do IPhone, o mercado de residências inteligentes também poderia se beneficiar de um eletroeletrônico com alto índice de penetração que alavancasse o ciclo de desenvolvimento das tecnologias domésticas. As TVs, por exemplo, provêem uma interface já bem conhecida e dominada pelo público. A disponibilidade de uma rede de comunicação e de uma plataforma de desenvolvimento aumentaria consideravelmente as chances de aparecimento de novas aplicações e serviços para as residências inteligentes.

Enquanto os grandes fabricantes de eletroeletrônicos não demonstram interesse, vários comitês - de iniciativa privada ou do governo - têm sido formados no Japão, Europa e Estados Unidos reunindo empresas interessadas no segmento de controle residencial com o objetivo de desenvolver suas próprias arquiteturas de redes e protocolos de comunicação como infraestrutura básica para suas aplicações de controle de iluminação, ar-condicionado, etc.

Se por um lado, essa miríade de protocolos e sistemas aumenta a confusão e o desinteresse dos consumidores, segundo Haddon (1995), essa diversidade talvez tenha sido o veículo que permitiu o diálogo entre empresas e indústrias que tiveram pouco contato anteriormente e que certamente detêm diferentes perspectivas e incertezas sobre esse mercado. Ele acredita que esse diálogo possa trazer resultados interessantes em termos de equipamentos e serviços mais atrativos para o público beneficiando o mercado de residências inteligentes.

Mercado Nacional Os fabricantes de produtos para automação residencial no Brasil ainda é, em grande parte, compreendido por pequenas e médias empresas. Elas desenvolvem suas próprias soluções e tentam se estabelecer no mercado enquanto não existe um padrão dominante. Outras empresas adotam uma estratégia diferente, representando no Brasil marcas internacionais já estabelecidas no exterior. O mercado de home theater também tem voltado seu interesse para a automação residencial. Com a venda de equipamentos pelos grandes magazines, a procura por projetos customizados e por serviços de instalação tem diminuído drasticamente. Uma das opções encontradas foi incorporar soluções de automação (na maioria, iluminação e persianas) à venda de telões, receptores, amplificadores e caixas acústicas. 


\section{A Evolução da Residência Inteligente}

As casas do futuro têm uma longa história, especialmente na ficção científica. Entre viagens ao espaço, vida em outros planetas e especulações, elas sempre estiveram presentes nos livros, na imprensa, nos filmes, na TV e mais recentemente, na Internet.

Na mídia, sempre houve muito apelo às imagens. As casas geralmente são exibidas criandose uma sensação de maravilha ou mesmo de fantasia. As imagens provêm uma fonte de inspiração para os fabricantes e consumidores se familiarizarem com o tema. Apesar de alguns verem com ceticismo, muitos acabam influenciados pelas vantagens e pelos sentimentos de sucesso e felicidade que elas despertam.

No fim do século passado, os computadores pessoais e a Internet permitiram o acesso remoto a músicas, vídeo e jogos tornando a residência um centro de entretenimento e, de certa forma, de convívio social, uma vez que as redes sociais e as mensagens instantâneas revolucionaram o modo como as pessoas - particularmente os jovens - se relacionam.

Apesar da crescente inserção da tecnologia no ambiente residencial, muitas das previsões sobre as casas do ano 2000 não se concretizaram. Infelizmente, carros voadores e a vida tranqüila no espaço ainda não fazem parte do nosso dia-a-dia. São situações que dependem de inúmeros fatores que o atual desenvolvimento tecnológico ainda não conseguiu resolver. Por outro lado, a casa automatizada, com portas e janelas automáticas, e videofones, também não é comum atualmente, mesmo com tecnologia disponível para tal.

Na prática, as empresas têm sido capazes de gerenciar remotamente dispositivos eletroeletrônicos há anos. Mas parece que isso não tem se mostrado conveniente e nem apresentado tantos benefícios assim para persuadir o morador a adquirir esses equipamentos. A frustração quanto ao modo de vida que estava previsto e que não aconteceu fez com que a mídia apresentasse as possibilidades da vida no futuro de forma mais pragmática e contida. Se por um lado muito do que foi previsto não se concretizou, devido à falta de tecnologia para tal, por outro lado inúmeros produtos que se acreditava que seriam comuns nas residências do século XXI, sequer deixaram de ser iniciativas isoladas.

Grande parte do tempo dedicado ao desenvolvimento de residências inteligentes envolve entender o estado da arte e tentar descobrir as necessidades dos seus moradores. Nesse sentido, conhecer a história da tecnologia sob o foco residencial e analisar as transformações que 
ocorreram na sociedade ao longo dos anos são formas de identificar métodos modernos para a construção de casas que estejam sintonizadas com os paradigmas e as necessidades do século XXI.

\subsection{A Introdução da Lâmpada Incandescente (1879 - 1920)}

No fim do século XIX, mais especificamente em 1879, a invenção da lâmpada incandescente por Thomas Edison alterou profundamente o estilo de vida das pessoas. Edson não inventou a eletricidade nem a primeira lâmpada elétrica. Muitos outros inventores ao redor do mundo já haviam transformado energia elétrica em luz. Mesmo a rede de corrente contínua que energizava suas lâmpadas, e que foi intensamente defendida por ele, foi substituída pela corrente alternada décadas depois. O importante é que Edison tornou a lâmpada comercialmente viável, alterando sua composição e estendendo sua duração para centenas de horas de uso, fora do ambiente de laboratório.

A lâmpada de Edison impulsionou todo o desenvolvimento e implantação da infraestrutura de geradores de energia, sistemas de distribuição e materiais elétricos. Ela viabilizou a implantação de linhas de transmissão e a instalação de cabeamento de cobre sob as ruas que, naquela época, devido aos materiais e técnicas disponíveis, era um processo difícil e caro. Isso motivou o desenvolvimento de outros equipamentos que se beneficiaram com as linhas de distribuição de energia já instaladas antes do fim do século XIX.

Quando as companhias começaram a prover energia elétrica para os consumidores residenciais, eles achavam que um ponto de energia, uma tomada, seria suficiente, pois não havia equipamentos que justificassem um ponto extra. Segundo Forty (1992), apenas as casas recém construídas e de alta classe tinham mais de duas tomadas. Havia certa apreensão com relação à eletricidade. Muitos mitos sobre choques e pessoas que morreram eletrocutadas espalharam temor sobre seu uso residencial. Mas, essa nova fonte de energia limpa e conveniente disparou a criação de equipamentos e serviços já nas primeiras décadas do século XX. Com o passar do tempo, os fabricantes desenvolveram vários equipamentos elétricos para o uso residencial e a possibilidade de usar a energia para outros fins gradualmente se tornou um incentivo para o donos de imóveis fazerem o investimento em infraestrutura.

A criação dos primeiros eletrodomésticos data ainda do fim do século XIX como, por exemplo, o ferro elétrico de passar roupa (1882) e o ventilador elétrico (1890). Aspiradores de pó à vácuo surgiriam em 1901 e, a partir de 1909, as máquinas de lavar roupa começaram também a auxiliar as donas de casas da época em suas rotinas diárias (IEEE, 2008). Em 1915, os refrigeradores substituíram as caixas de gelo e a entrega de gelo à domicílio começou a de- 
saparecer. Torradeiras elétricas eram produzidas com desenhos elaborados e toques artísticos de forma a ocupar a mesa de jantar. Um dos fatores que contribuíram para alavancar a venda de eletrodomésticos nesta época foi a utilização de novos núcleos ferromagnéticos que possibilitou a diminuição do tamanho dos motores elétricos e uma subseqüente queda no preço. Anteriormente, um volumoso motor movimentava dezenas de ferramentas que eram conectadas por meio de correias e engrenagens. Era um abuso pensar que cada eletrodoméstico poderia ter seu próprio motor independente.

Durante o início do século $\mathrm{XX}$, um dos obstáculos que a indústria teve que vencer para persuadir os consumidores domésticos a utilizar a eletricidade foi o medo do desconhecido. As mulheres, particularmente aquelas que nunca tinham trabalhado fora, não haviam tido experiência com a eletricidade e também não tiveram nenhuma oportunidade de aprender. Nessa época, a eletricidade ainda não era popular (8\% das casas americanas tinham eletricidade (DELONG, 1997)) e muitas donas de casas a viam como uma fantasia. A propaganda de eletrodomésticos alegava que, com a ajuda da tecnologia, uma pessoa sozinha (inevitavelmente uma mulher) poderia dar conta de todo o trabalho doméstico e ainda ter tempo para seus passatempos e descanso (HARDYMENT, 1988). Uma ironia pois, segundo Mokyr (2000), a introdução desses equipamentos fez com que as donas de casa gastassem mais tempo com as tarefas domésticas do que antes. Com as máquinas de lavar, aspiradores de pó e a casa iluminada, elas tinham que lavar as roupas e limpar o chão mais frequientemente, pois os padrões de higiene haviam aumentado.

\subsection{As Primeiras Casas do Futuro (1920-39)}

No começo da década de 1920, 35\% das casas americanas tinham eletricidade (DELONG, 1997) e muitas mulheres já haviam se familiarizado com a energia elétrica em seus locais de trabalho. A Primeira Guerra havia aberto diversos postos de trabalho que foram preenchidos pelas mulheres especialmente em áreas de engenharia e fabricação de munição (SPRENGER; WEBB, 1993). O interesse pelo mote Casa do Futuro começa a surgir então na década de 1930 como apelo para a venda de eletrodomésticos.

Em 1930, a General Electric (GE) exibia a House of Magic na maioria das feiras americanas. House of Magic era inicialmente um laboratório de desenvolvimento de novas tecnologias criado em 1900. Lá trabalhavam os melhores engenheiros da época e de onde saíram grandes avanços em imagens médicas, tecnologias de rádio e equipamentos residenciais que fazem parte do portfólio da GE até hoje. O laboratório fez tanto sucesso que ele se transformou em um showroom itinerante de novos produtos. Em um dos pavilhões, uma casa com belas mulheres 
imitavam donas de casas, usando os eletrodomésticos mais modernos da época.

A Westinghouse, uma das maiores concorrentes da GE na época, para não ficar atrás, construiu a Home of Tomorrow, na cidade de Mansfield, Ohio, em 1934. Era uma residência-laboratório onde os engenheiros da companhia viviam temporariamente com suas famílias para testarem novos conceitos, além de servir como showroom para enaltecer os próprios produtos da empresa. Alguns dos avanços tecnológicos encontrados na casa eram: ar-condicionado, portão automático, portas deslizantes automáticas, lavanderia com todos os equipamentos elétricos, alarme de segurança, 140 tomadas e 320 pontos de luz. Todos os equipamentos juntos consumiam 30 vezes mais potência que a média das casas da época (HORRIGAN, 1988).

Em 1933, a Feira Mundial de Chicago foi criada para celebrar as inovações em arquitetura, ciência, transportes e tecnologia. Uma das exibições mais interessantes foi a Homes of Tomorrow que exaltava os benefícios das casas modernas e demonstrava novas técnicas de construção e de emprego de materiais. Várias casas foram construídas sob novos conceitos arquitetônicos e exibiam novas tecnologias como um sistema central de ar condicionado e lavadoras de louça. Em uma das casas havia até um hangar para aviões junto à garagem. Na onda otimista da época, os organizadores da feira acreditavam que todas as famílias do futuro teriam seus próprios aviões. Em 1936, com o fim da feira, muitas casas foram transferidas de lugar e algumas resistem até hoje.

\subsection{A Segunda Guerra (1939-45)}

No começo da Segunda Guerra, $65 \%$ das casas do Reino Unido e $80 \%$ das casas americanas já tinham eletricidade. Desses domicílios com eletricidade nos Estados Unidos, quase a totalidade tinha ferros elétricos, dois terços tinham máquinas de lavar roupa e dois terços tinham refrigeradores (DELONG, 1997).

Ainda oficialmente fora da Segunda Guerra Mundial, os Estados Unidos exibiam maravilhas futurísticas na The World of Tomorrow, uma feira que aconteceu nos anos de 1939 e 1940 na cidade de Nova York e que claramente enfatizava os benefícios do modo americano de se viver.

Em um dos pavilhões, a Westinghouse exibia o robô Elektro, de dois metros de altura, que dizia como a vida da dona de casa estaria livre das rotinas diárias se ela utilizasse os eletrodomésticos da empresa. O próprio presidente da Westinghouse, George Bucher, publicou um artigo intitulado The Electric Home of the Future na revista Popular Mechanics enaltecendo os benefícios de energia elétrica na vida doméstica (BUCHER, 1939). Sua visão era que a civiliza- 
ção já se mostrava dependente dessa conveniente "forma de energia domesticada pelo homem". Bucher descreveu um cenário futurístico com várias centrais espalhadas pelos cômodos para controlar todos os eletrodomésticos de qualquer lugar da casa. Afirmava que mesmo que os fogões já tivessem seus próprios botões de temperatura e temporizadores, não via o porquê de não poder controlar os equipamentos remotamente no futuro. Ele apostava na radiofreqüência tanto para esse fim, a transmissão de informações e controle remoto, quanto para o cozimento de alimentos. E foi além, descrevendo o enorme potencial em serviços e equipamentos que a energia elétrica traria em um futuro próximo, como ar-condicionado com efeito esterilizante para remover as bactérias do ar e sistemas de iluminação com lâmpadas coloridas para melhorar o humor das pessoas quando chegavam em casa.

Durante a guerra, as propagandas enalteciam a mulher, demonstrando que elas eram capazes de assumir os papéis dos homens, deixando-os livres para irem para as forças armadas. Durante esse período, elas se acostumaram a trabalhar fora de casa e se tornaram tecnicamente competentes. A indústria da guerra abriu as portas para que elas trabalhassem em fábricas de munição, carros, navios e aviões. Quase um milhão de mulheres ocuparam cargos no governo e também cargos normalmente ocupados por homens como caixas de banco e vendedores de sapatos (NWHM, 2008). Embora, todo o panorama mundial tenha mudado após a Segunda Guerra Mundial, e parte dos combatentes tenha voltado aos seus postos de trabalho, esse período foi primordial para o crescimento da tecnologia doméstica nos anos posteriores.

\subsection{A Maravilha do Pós-Guerra (1946-59)}

Com o fim da Segunda Guerra, a propaganda havia se revertido. Agora, o lugar da mulher era de volta ao lar como dona de casa para que os homens, recém chegados da guerra, pudessem ter seus empregos de volta. Muitas mulheres ainda mantiveram seus postos nas fábricas de rádio e televisores, pois se sujeitavam a receber menores salários do que os dos homens (IEEE, 2008). As propagandas mostravam as mulheres em casa acenando para seus maridos e filhos enquanto eles saíam para o trabalho e escola. A mensagem por trás era para que as mulheres dessem atenção às suas atividades domésticas - Germs rather than Germans (Melhor os germes do que os Alemães) como era dito na época. O desenho das casas havia mudado em ordem a acomodar refrigeradores e máquinas de lavar roupas e o conceito de sala de TV foi introduzido nessa época visto que a venda de televisores cresceu vertiginosamente (ALDRICH, 2003).

Em 1950, a Associated Press publicou um artigo intitulado How Experts Think We'll Live in 2000 A.D (Como os Especialistas Imaginam Que Nós Iremos Viver no Ano 2000). O artigo cobria o futuro dos filmes, dos vôos comerciais, das viagens espaciais, medicina, entre outros 
tópicos. Em um trecho sobre construção, ele revelava:

Pessoas irão viver em casas tão automáticas que os botões serão trocados por leitura de impressão digital e controles por voz. Hoje, algumas pessoas podem apertar um botão e fechar uma janela - outras podem ligar a cafeteira na cozinha. Amanhã, essas tarefas serão realizadas pelo calor dos seus dedos, assim como são os elevadores dos prédios comerciais mais novos - ou por um mero sussurro no interfone. [...] Todas as casas terão a temperatura controlada a níveis confortáveis durante todo o ano [...]. O calor para o aquecimento das casas será retirado das profundezas da Terra [...] O telefone terá os fios transformados para rádio e será equipado com telas de televisão.

Vale ressaltar que quando o artigo acima menciona que algumas pessoas já podiam fechar uma janela ou ligar a cafeteira por meio do toque de um botão, provavelmente ele se referia ao pequeno número de afortunados, aficionados em eletrônica e mecânica, que desenvolveram dispositivos de controle residencial. Na década de 1950, as revistas populares de mecânica e eletrônica exibiam alguns projetos de casas automatizadas. Iluminação automática com sensores de presença, aquecimento de piso, janelas que abriam e fechavam sozinhas dependendo das condições climáticas eram algumas das inovações apresentadas na época. A House of Magic, de iniciativa independente, é um exemplo de como a criatividade aliada a conceitos de física e eletricidade poderia trazer conforto e algumas extravagâncias para dentro de casa (STIMSON, 1954).

Em 1957, a Disneylândia inaugurou a Monsanto House of the Future. Com aproximadamente $120 \mathrm{~m}^{2}$ a casa foi totalmente construída com plástico. Desde a cobertura e o piso, até cadeiras, copos e pratos, foram consumidos 15 toneladas de plástico. A indústria química Monsanto, a patrocinadora do projeto, queria passar a idéia que o plástico seria o material do futuro e que as superfícies plásticas seriam mais fáceis de limpar e manter.

Apesar do patrocínio da Monsanto, a casa foi projetada e construída pelo MIT (Massachussets Institute of Technology, EUA) e trazia várias novidades para época como fornos de microondas, telefones com viva voz e escovas de dente elétricas. Algumas invenções como máquinas de lavar louças ultra-sônica e preservação atômica de alimentos também foram sugeridas.

Mais de 20 milhões de pessoas visitaram a casa durante os 10 anos que ficou em exposição na World of Tomorrow, uma área futurística dentro da Disneylândia, na Califórnia. Em 1967, a casa foi demolida. 


\subsection{A Emancipação da Mulher (1960 - 75)}

O modelo de dona de casa dos anos 1950 estava ameaçado com o ritmo frenético dos anos 1960. Segundo Aldrich (2003), com a pílula anticoncepcional e o controle de ter ou não ter filhos, muitas mulheres decidiram sair de casa para trabalhar. A promessa dos eletrodomésticos em aliviar as tarefas rotineiras conquistou essas donas de casa que tentavam entrar no mercado de trabalho. Nessa época, torradeiras, cafeteiras, máquinas de lavar louça, processadores de alimentos, aspiradores de pó, barbeadores elétricos, máquinas de costura e máquinas de lavar roupas se tornaram comuns. Outras tecnologias como aquecimento central e termostatos para o controle de temperatura também se popularizaram.

A casa de Stirling Moss, um famoso corredor de carros inglês é, provavelmente, o maior exemplo do que era possível naquela época. A casa de Moss era repleta de botões que comandavam janelas, condicionadores de ar e inúmeros painéis que subiam e desciam escondendo TVs e equipamentos de som. Mesas e balcões permitiam seu ajuste elétrico de altura aumentando o conforto. Até a banheira podia ser controlada de outros cômodos. Atualmente, sua casa ainda mantém muitos dos dispositivos originais daquela época e ainda desperta a curiosidade da mídia (MOSS, 2006).

Em 1974, após o início da Crise Mundial do Petróleo, os consumidores foram obrigados a rever suas opções de fontes de energia. O preço do petróleo e seus derivados subiram drasticamente e a opção mais viável para aquecer o ambiente e os reservatórios de água foi a energia elétrica. Para reduzir os efeitos do aumento da demanda no horário de pico, as concessionárias de energia do Reino Unido lançaram o sistema de tarifas diferenciadas com redução de tarifa durante a noite. A intenção era beneficiar o consumidor com tarifas menores incentivando-o a usar os grandes equipamentos consumidores de energia como aquecedores de água ou acumuladores de calor em horários fora do pico comercial. Reduzindo os picos de consumo, elas podem gerenciar melhor suas reservas e adiar os investimentos em novas fontes de energia. O sistema de tarifas diferenciadas como forma de gerenciamento de demanda já havia sido inventado em 1952 (HORSTMANN, 2008), mas foi o aumento súbito da procura por eletricidade devido à alta do petróleo que o tornou imprescindível. Vários sistemas e políticas têm sido implantados desde então. Na época, os primeiros receberam o nome de Electrisave 9, Electrisave 10 e, posteriormente em 1979, Economy 7. 


\subsection{A Primeira Onda da Automação Residencial (1975 - 90)}

Na década de 1970, quando os videogames, videocassetes e os computadores pessoais começaram a disputar a conexão com a TV, normalmente já tomada pela antena, vários fabricantes notaram os benefícios de se interligar os equipamentos residenciais de uma forma compartilhada. Um grupo de empresas iniciou então o trabalho de padronização dessas conexões e em 1977 o conector SCART (Syndicat des Constructeurs d'Appareils Radiorécepteurs et Téléviseurs, conhecido também pelo termo Péritel ou Euroconnector) foi criado. Por meio dos cabos e conectores SCART, sinais analógicos de áudio e vídeo e alguns de chaveamento eram transportados de um equipamento a outro, de forma encadeada, assim não havia a necessidade de desconectar o videocassete para usar o videogame, por exemplo. O SCART representou um grande avanço, pois, além de padronizar as conexões, foi a primeira forma de interligação em rede de eletrodomésticos.

No começo dos anos 1980, 75\% dos moradores do Reino Unido tinham TV em cores, e no fim da década, 50\% tinham videocassete (BOWDEN; OFFER, 1994). Fornos de microondas, freezers e secadoras de roupa se tornaram comuns e houve também a introdução dos aparelhos de telefones sem fio. TVs, videocassetes e outros equipamentos de entretenimento tinham comando por controle remoto e mostradores com dígitos eletroluminescentes (KRUESI; ROGERS, 1982). Nos eletrodomésticos da linha branca (geladeira, fogão, etc.), os fornos de microondas foram os primeiros a utilizarem microprocessadores para o gerenciamento de suas funções e teclados com dígitos para a programação de tarefas e ajustes. Geladeiras e fogões permaneceram por mais tempo com as tradicionais chaves mecânicas. As máquinas de lavar louças, máquinas de lavar roupas e secadoras de roupas foram gradativamente incorporando teclados e microprocessadores ao longo dos anos. As chaves eletromecânicas eram um limite físico para a expansão do número de operações e ciclos que se desejava obter comercialmente (BELL, 1985). Adicionalmente, a qualidade e precisão superiores dos sensores eletrônicos aliado à contínua redução dos custos desses componentes ampliaram seu uso em eletrodomésticos e possibilitaram métodos mais eficientes de lavagem e secagem.

Segundo Fiedler (2004), a gradual inserção de circuitos integrados e semicondutores na produção dos eletrodomésticos vem trazendo vários benefícios ao longo de toda a cadeia produtiva e de consumo. Sob o ponto de vista do fabricante, a utilização dos semicondutores tem tornado mais flexível o sistema de produção no chão de fábrica e tem mostrado um aumento na confiabilidade dos circuitos de controle. Esse último fator, por si só, tem reduzido os gastos com manutenção e possibilitado a extensão dos prazos de garantia oferecidos ao consumidor, melhorando a imagem da empresa no mercado. Sob o ponto de vista do consumidor, é mais 
conveniente, pois possibilita a redução de tamanho, a melhoria do design e apresentação, a redução do consumo de energia e introduz novas formas de programação e uso. Como exemplo, as novas técnicas de controle permitiram o uso de menor quantidade de água e em menor temperatura nos ciclos das lavadoras de roupa.

O uso de circuitos integrados e semicondutores em eletrodomésticos também despertou o interesse dos desenvolvedores para novas aplicações. Com a lógica eletrônica miniaturizada, existia a possibilidade de criar meios para a troca de informações entre eletroeletrônicos e com isso controlar equipamentos à distância.

Internamente, a residência também estava sofrendo um processo de metamorfose. Os computadores pessoais, modems, videodiscos e equipamentos de som de alta fidelidade transformaram os cômodos em ambientes polivalentes. Em um momento tinha-se um escritório, em outro um centro de entretenimento e depois um local para descanso.

Em resumo, o panorama tecnológico residencial do começo dos anos 1980 criou um amplo espaço de possibilidades para a automação residencial. Várias empresas começaram a construir casas piloto para mostrar suas soluções e produtos. Pela primeira vez se tornou factível considerar a produção de equipamentos comerciais e lucrativos que poderiam oferecer novas opções de controles e sistemas sofisticados.

Diante dessa situação, a indústria começou a investir fortemente no desenvolvimento de padrões de redes de comunicação para a interconexão de eletroeletrônicos em ambientes residenciais. Ela acreditava que quem conseguisse impor um padrão de rede doméstica deteria a chave para a exploração de potenciais produtos e aplicações. Assim, várias iniciativas surgiram e o desenvolvimento de aplicações e produtos teve menor prioridade.

\subsubsection{Iniciativas Européias}

Muitos autores creditam o marco inicial da automação residencial à criação do X10, em 1975, pelos engenheiros da empresa escocesa, Pico Electronics. O X10 é um sistema de comando remoto de dispositivos que utiliza a própria rede elétrica convencional para transmitir seus sinais de controle. Fácil de instalar e usar, estima-se que se tenha vendido milhões de unidades no mundo inteiro e ainda é sucesso de vendas, sendo considerado sinônimo de automação residencial.

A Philips, aproveitando a idéia do SCART, criou a especificação do D2B (Domestic Digital Bus) no fim da década de 1970. Inicialmente, foi um protocolo de rede serial para o controle de equipamentos audiovisuais utilizando dois pinos do conector SCART, tornando-se padrão na 
Europa e no Japão. Uma das possibilidades do D2B era a troca de informações entre TVs e videocassetes. Uma vez iniciado um filme no videocassete, o televisor teria seu canal alterado automaticamente para a exibição. O D2B foi também utilizado no controle de equipamentos de som de alta fidelidade e no posicionamento de antenas parabólicas, mas, embora seu uso para automação residencial e segurança já fosse previsto na época da sua concepção, a Philips não mencionou essas possibilidades nas divulgações iniciais do produto (KAPLINSKY, 1981). O D2B seria vendido com foco no mercado de áudio e vídeo. Mais tarde, em 1987, quando se percebeu o importante papel do D2B no mercado de automação, a Philips convenceu os japoneses a incorporarem o D2B no Home Bus System (HBS) adotado mundialmente exceto nos EUA, onde o CEBus e o Echelon dominavam o mercado. Em 1991, uma extensão do D2B foi incluída no projeto ESPRIT Home Systems (WACKS, 1992).

No Reino Unido, o National Economic Development Office (NEDO) foi um dos primeiros a discutir automação residencial na Europa lançando em 1980 um documento sobre o assunto e iniciando em 1984 uma força tarefa intitulada Interactive Home Systems. As propostas e discussões desse fórum vieram a influenciar as futuras iniciativas européias como o Eureka e ESPRIT, pois muitas empresas européias começaram a perceber que poderiam perder a chance de entrarem em um lucrativo mercado caso as iniciativas japonesas obtivessem sucesso. Os encontros promovidos pelo NEDO encorajaram algumas empresas, dentre elas a Thorn EMI, Thomson, Siemens e a Philips, a iniciarem um programa de colaboração para o desenvolvimento de sistemas residenciais e que o programa Eureka seria uma possibilidade de conseguirem fundos para a empreitada.

O programa Eureka, iniciado em 1985 e em vigor até hoje, tem sido uma grande iniciativa para aumentar a produtividade e competitividade da indústria e do mercado europeus. Segundo Grata (1989), em muitos ramos da tecnologia, como no caso dos circuitos integrados, as empresas européias não figuravam entre as 10 maiores do mundo. A proposta tem sido promover a colaboração entre empresas, governos e universidades em áreas vitais e onde o custo de desenvolvimento é alto. O resultado tem sido uma série de programas de desenvolvimento em comunicações, biologia, lasers, robótica e energia.

Sob a chancela do Eureka, surgiu em dezembro de 1986, um programa de dois anos intitulado Eureka - Integrated Home Systems (Eureka-IHS), como uma tentativa européia de propor um sistema residencial único e padrão. O Eureka-IHS retomou algumas discussões iniciadas no NEDO e, mesmo sob uma nuvem de desavenças e contrariedades, resultou em especificações de protocolos associados a diversos meios de transmissão e um rascunho de uma linguagem de controle. Em 1989, esses resultados do Eureka-IHS foram utilizados por outro programa, o ESPRIT HS HOME (ESPRIT Home Systems HOME, 1989 - 1991) (DOOTINGH, 1990). 
O ESPRIT HS HOME, sua continuação, o ESPRIT HS IHH, (ESPRIT Home Systems Integrated Interactive Home, 1991- 1992) e outros projetos relacionados fazem parte do consórcio ESPRIT (European Strategic Programme for Research and Development in Information Technology, 1984 - 1998), criado pela Comissão Européia (CE) para revitalizar a pesquisa e o desenvolvimento de tecnologias da informação na Europa.

Com o lançamento da arquitetura ESPRIT HS, a Comissão Européia percebeu que alguma associação comercial deveria cuidar dos direitos intelectuais adquiridos em todos os anos de projeto ESPRIT. Isso encorajaria também outras empresas e instituições a participarem dos trabalhos e definição de um padrão. Como resultado, foi criada a EHSA (European Home Systems Association) em 1992.

Com a recessão da indústria da construção civil na época e com o receio que a situação demorasse para se normalizar, a especificação EHS foi estendida também para os prédios comerciais. Isso colocou a EHS em competição direta com os sistemas EIBus e Batibus pela fatia de mercado de sistemas de controle prediais.

\subsubsection{Iniciativas Japonesas}

Segundo Cawson, Haddon e Miles (1995), o termo automação residencial foi utilizado originalmente pelas companhias japonesas, as primeiras a mostrarem interesse em desenvolver sistemas completos de controle doméstico. Os primeiros sistemas foram propostos pela Hitachi e Matsushita em 1978.

As primeiras intenções para se obter uma padronização datam de 1981. Mas só em setembro de 1988, depois de sete comitês envolvendo várias organizações, é que surgiu o padrão Home Bus System (HBS). No entanto, poucos produtos foram lançados na época baseados nesse padrão. O Super HomeBus System (S-HBS), uma versão compatível com o HBS, mas com serviços direcionados para conjuntos de apartamentos, teve relativo sucesso e algumas unidades foram cabeadas com essa solução (HAMABE et al., 1988).

Em paralelo a essas iniciativas, a TRON Intelligent House, uma parceria da Universidade de Tókio com várias empresas, desenvolveu uma casa piloto em 1989 nas imediações de Tókio. Seu design era baseado no conceito: "a fusão do homem, natureza e computadores" (SAKAMURA, 1990). A casa contava com um sistema de telas, cada uma presente em um cômodo, que agregava as informações provenientes da TV, vídeo porteiros, telefones, intercomunicadores e sensores de segurança. Na cozinha, um equipamento de videodisco (a geração anterior ao DVD) guardava todas as receitas e no banheiro, todas as funções de lavagem e secagem 
das mãos eram automatizadas. O sistema de controle de temperatura e umidade verificava as condições externas e internas por meio de sensores e gerenciava não só o equipamento de ar condicionado como também abria e fechava janelas e breezes dependendo do clima. Havia também uma preocupação em se criar interfaces e sistemas que fossem de fácil utilização por todos os moradores da casa.

Apesar de servir como um laboratório de teste para os recém criados sistemas de automação, redes e computação, a casa recebeu duras críticas da imprensa japonesa. Eles diziam que seu custo de desenvolvimento era abusivo e que parecia uma casa assombrada (devido às janelas abrirem e fecharem automaticamente). Após três anos de funcionamento, a casa foi desativada (SAKAMURA, 1990).

\subsubsection{Iniciativas Norte-Americanas}

Os primeiros produtos comercializados nos Estados Unidos foram o X10 em 1978, vendidos inicialmente nas lojas da RadioShack e posteriormente pela Sears.

A Honeywell foi uma das primeiras a investigar as possibilidades de se adicionar o conceito de automação residencial aos seus produtos de aquecimento, ventilação e ar condicionado. Em 1978, iniciou a construção de uma casa piloto que serviria para a demonstração desses novos produtos. Em 1980, a tecnologia de rede de comunicação utilizada nesta casa para interligar os dispositivos foi introduzida na sua linha mais nobre de equipamentos de segurança, e finalmente, em 1992, foi lançada a linha Total Home nos Estados Unidos.

Em 1984, a General Electric (GE) em parceria com a Pico/X10 lançou o sistema HomeMinder (FISCHETTI; HORGAN; WALLICH, 1985). Era um pouco menor que um videocassete e permitia controlar módulos X10 por meio de um controle remoto. O HomeMinder era conveniente pois utilizava a TV para exibir seus menus e fotos dos cômodos como imagens de fundo. Apesar de apresentar funções muito a frente de sua época ele desapareceu do mercado quando o departamento da GE responsável pelo produto foi fechado. A Pico/X10 comprou todo o estoque da GE, reestilizou-o e conseguiu revender as últimas unidades para a RadioShack (RYE, 1999).

Na década de 1980, houve duas grandes iniciativas no sentido de criar um suporte ao desenvolvimento de produtos para automação residencial nos EUA: o CEBus (Consumer Electronic Bus) e o SmartHouse. Em 1984, doze empresas participantes do Consumer Electronics Group da EIA (Electronic Industries Alliance) se reuniram para definir um protocolo padrão de comunicação entre equipamentos residenciais. Esse esforço havia começado dois anos antes na 
tentativa de se estabelecer um padrão comum de transmissão de sinais infravermelhos para controle remotos. Os membros desse comitê entendiam que os futuros equipamentos residenciais seriam interconectados e que trocariam informações de controle entre eles próprios ou até mesmo com equipamentos externos à casa. No começo da década de 1990, o número inicial de doze participantes se expandiu para mais de 250 incluindo subsidiárias de empresas japonesas e européias. Em 1992, o padrão CEBus foi oficialmente lançado e apresentado pela primeira vez ao público na Bright Home, uma casa construída com toda a infraestrutura necessária para abrigar produtos compatíveis com o CEBus (DAVIDSON, 1992).

Em paralelo, a National Association of Home Builders Research Foundation ( NAHB) lançou o projeto Smart House em 1984. Aproveitando uma emenda aprovada pelo congresso americano que permitia às empresas que se organizassem a fim de promover pesquisas e desenvolvimento formou a Smart House Limited Partnership. A NAHB, uma das maiores associações americanas, representando construtores de residências e pequenos prédios, convidou várias empresas a participarem do grupo. Elas poderiam usar o selo Smart House e teriam exclusividade parcial: apenas três empresas poderiam disputar cada segmento durante os primeiros sete anos. O foco inicial era desenvolver um sistema seguro e integrado de cabeamento de energia elétrica e dados de forma que apenas haveria energia nos cabos se uma lâmpada ou equipamento a requisitasse. Isso evitaria choques nas tomadas e curtos-circuitos. A promessa era que os custos com instalação e mão de obra se reduziriam. Mais tarde, a idéia de criar um sistema de automação tomou lugar e, em 1987, um protótipo foi desenvolvido. Temendo que o mercado de imóveis entrasse em crise devido à espera por um novo padrão de cabeamento, os construtores pressionaram o consórcio e, em 1991, o sistema foi lançado. No entanto, devido a crise, a produção de muitos produtos foi postergada.

\subsubsection{O Advento dos Computadores Pessoais}

Quando Steve Wozniak, em junho de 1975, digitou os primeiros caracteres no Apple I, dando vida ao primeiro computador pessoal qual tal conhecemos hoje, com monitor, central de processamento e teclado, talvez não tivesse noção no momento das inúmeras possibilidades que essa ferramenta seria capaz. Todo computador antes do Apple I tinha um painel frontal com chaves para a entrada de dados e mini lâmpadas para o monitoramento das atividades (WOZNIAK; SMITH, 2006). Essas modificações expandiram as possibilidades de programação de tal forma que no começo da década de 1980, um usuário residencial já era capaz de se entreter com os jogos ou realizar seu trabalho em casa com as planilhas e processadores de texto.

Com essa crescente evolução, foi natural o surgimento de módulos de controle de equipa- 
mentos residenciais para uso com os computadores. Várias aplicações interessantes podiam ser desenvolvidas com esses módulos e com os softwares disponibilizados para o gerenciamento de tarefas. Alguns exemplos de casas automatizadas publicadas em meados dos anos 1980 (e.g. Fischetti, Horgan e Wallich (1985), Yakal (1986), Darling (1984), Perry (1985b), Perry (1985a)) demonstram a utilização de computadores Apple II, Commodore 64, VIC 20 ou IBM PC para gerenciar equipamentos de HVAC, segurança e iluminação.

Os módulos de controle eram interfaces que convertiam os sinais elétricos de modo que o computador pudesse entender as informações provenientes de sensores e gerenciar externamente os atuadores, normalmente relés de contato. Em sua maioria, esses módulos eram conectados nas portas serial ou paralela do computador - na época não havia a diversidade e o número de portas para conexão de periféricos como se pode encontrar atualmente - e transmitiam diretamente os sinais sem o uso de um sistema de transmissão de dados por rede, necessitando a instalação de cabeamento dedicado do computador até cada um dos equipamentos que estavam sendo controlados.

A exceção eram os módulos X10 que se beneficiavam da própria rede elétrica para transmitir seus sinais de controle. Dessa forma o computador podia atuar tanto como um dispositivo de entrada, permitindo ao usuário controlar a intensidade da iluminação e o liga-desliga de eletrodomésticos, quanto mostrar graficamente na tela o status desses dispositivos. No início da década de 1980, era comum encontrar em lojas de eletrônica, especialmente nos EUA, interfaces para conectar dispositivos X10 aos computadores e obtiveram grande sucesso entre aficionados.

Apesar dos benefícios, a utilização dos computadores para controlar os sistemas de automação apresentava alguns inconvenientes. Primeiro, eles deveriam ficar ligados dia e noite para monitorarem e gerenciarem os sistemas de controle da casa. Em uma época em que o computador era usado apenas para jogos e planilhas de cálculo, tê-lo constantemente ligado era visto como desperdício de energia. Outro problema era que, devido às limitações do hardware e do próprio sistema operacional, o programa gerenciador não podia funcionar concomitantemente com os outros aplicativos. Isso significava que nos momentos de lazer ou na hora de trabalho em que jogos, planilhas ou processadores de texto estavam sendo utilizados, a casa ficava sem comando. Nesse caso, as possibilidades seriam destinar um computador exclusivamente para controlar os sistemas de automação ou adquirir um que permitisse executar várias tarefas ao mesmo tempo, possível na época, mas a um custo proibitivo. 


\subsection{A Era dos Ambientes Inteligentes (1991 - Presente)}

A popularização do computador pessoal e da Internet no ambiente residencial, paralelamente ao contínuo desenvolvimento de tecnologias de comunicação e informação, alteraram profundamente o modo como as pessoas trabalhavam, estudavam, se comunicavam e se entretiam no início da década de 1990. Inicialmente, os computadores representavam uma extensão do escritório, mas o email, as mensagens instantâneas e a World Wide Web disponibilizou, de forma sem precedentes, o acesso à informação. Isso não apenas permitiu que o computador pudesse ser usado para educação e entretenimento mas também estimulou o desenvolvimento de novas aplicações tornando-o uma ferramenta social, criando-se várias razões para que as pessoas tivessem um em casa (VENKATESH, 1996).

A evolução das interfaces na direção de maior adaptabilidade às características naturais de interação do ser humano tem tornado mais simples e fácil a utilização do computador. Primeiro, o painel de luzes, depois os caracteres e mais recentemente, as interfaces gráficas e a manipulação direta com o mouse possibilitaram um aumento na velocidade na troca de informações entre o homem e a máquina. Porém, a apresentação tradicional do computador de mesa com mouse, teclado e monitor começou a ser tornar um fator limitante ao desenvolvimento de novas aplicações uma vez que toda a interação requeria a presença física do usuário muito próxima da tela. Heierman e Cook (2003) relembram que na ficção científica muitas das interações com as máquinas eram no nível humano e não no nível das máquinas. Nesses ambientes futurísticos, a voz e o comportamento eram usados para se comunicar com elas, sem a necessidade de pedido de atenção especial, geralmente de forma natural e não intrusiva.

A busca por formas mais naturais de relacionamento homem-máquina, por meio de gestos, fala, afeto e contexto, influenciou a pesquisa de tecnologia residencial estabelecidas nas décadas passadas. Esse processo despertou o interesse pelos ambientes interativos onde os computadores seriam não apenas mais amigáveis como também essencialmente invisíveis para o usuário.

$\mathrm{Na}$ cronologia das iniciativas em residências inteligentes, até o início da década de 1990, observa-se o direcionamento das pesquisas para o desenvolvimento de redes, protocolos e sistemas de controle. Mas, nessa nova fase, a possibilidade de múltiplas formas de interação entre o mundo real e virtual, por meio de uma infraestrutura computacional, transparente, envolvendo o usuário, sentindo e reagindo aos seus impulsos, desencadeou várias iniciativas de pesquisa e desenvolvimento de ambientes inteligentes.

O marco inicial dessa nova geração foi o trabalho de Mark Weiser, The Computer of the 
21st Century, publicado em 1991 (WEISER, 1991). Seu conceito de Computação Ubíqua (UbiComp), termo que ele mesmo criou, teve uma enorme influência no meio científico e em outras iniciativas como a Computação Pervasiva da IBM (PerComp) e os Ambientes Inteligentes da Philips (AmI).

A era da UbiComp dependia fundamentalmente da ampla disponibilidade dos serviços em qualquer lugar e momento. No entanto, essa disponibilidade demandava uma série de recursos tecnológicos que não era factível na época e que acabou gerando uma corrida para o desenvolvimento desses recursos. Ao longo de toda a década de 1990 surgiram novas interfaces, sistemas de localização, novas tecnologias de sensores, atuadores, etiquetas eletrônicas, módulos de computação vestível e toda a infraestrutura relacionada à interconexão desses dispositivos em rede com novos modelos de sistemas operacionais, métodos de gerenciamento e protocolos de transmissão de dados.

Outro ponto interessante é que a exploração dos novos paradigmas da interação humanomáquina sob a visão da Computação Ubíqua requereu protótipos em escala. Algumas universidades e empresas criaram ambientes onde pessoas pudessem vivenciar situações e cenários, monitoradas por uma ampla rede de sensores e interagir com diversos tipos de dispositivos computacionais e de comunicação. Segundo Abowd, Atkeson e Essa (1998), a pesquisa de ambientes inteligentes necessita de espaços físicos para acomodar seus habitantes e analisar seus comportamentos. Essa observação ajuda a revelar os benefícios de cada tecnologia e identificar quais seriam aptas a serem usadas no futuro.

A pesquisa em ambientes inteligentes evoluiu consideravelmente desde as propostas de Weiser. O início da década de 1990 se caracterizou pelo desenvolvimento dos primeiros dispositivos inteligentes como o Active Badge (WANT et al., 1992) instalado na Universidade de Cambridge, Inglaterra, que usava sinais de infravermelho para localizar as pessoas dentro do laboratório. Alguns protótipos de residências-laboratórios surgiram nessa época como a Adaptive House da Universidade do Colorado, EUA, 1991 (MOZER, 1998).

Atualmente, existem vários projetos de residências e ambientes inteligentes sendo desenvolvidos por universidades e pela indústria. $\mathrm{O}$ foco se estende desde a infraestrutura, redes de comunicação, até o desenho de interfaces, metodologias de controle de dispositivos, questões de segurança, privacidade, etc. Alguns estudos se utilizaram de vários sensores em objetos não computacionais (como sensores de pressão em cadeiras) para monitorar a presença de pessoas. Outras abordagens captam informações do meio com câmeras e microfones e, por meio de análise visual e sonora, provêm informações de posição, identidade, direção, expressão facial e gestos para predizer a ação e a intenção dos moradores. 


\subsubsection{Iniciativas Acadêmicas}

\section{Adaptive House (University of Colorado)}

Em 1991, o professor Michael Mozer da Universidade do Colorado comprou e reformou um prédio de uma antiga escola, com mais de 90 anos, tornando-a uma residência-laboratório. Com mais de $8 \mathrm{~km}$ de cabos e dezenas de sensores e atuadores, Mozer e sua equipe desenvolveram algumas técnicas de controle de dispositivos baseadas na observação e no monitoramento contínuo de dados coletados diretamente de um ambiente real (MOZER, 2005).

A análise das informações provenientes dos sensores de temperatura ambiente, nível de iluminação, nível sonoro, posicionamento de portas e janelas, clima e insolação permite descrever os hábitos diários de seus ocupantes e, eventualmente, aprender a antecipar suas necessidades. O sistema de controle ACHE (Adaptive Control of Home Environments) utiliza redes neurais para gerenciar os atuadores que controlam a iluminação, o aquecedor de água e o sistema de ar condicionado/aquecimento alterando o fluxo de ar quente proveniente de aquecedores elétricos e a gás (MOZER, 1998).

\section{Aware Home (Georgia Tech)}

Em 1995, Gregory Abowd e Chris Atkeson fundaram o Future Environment Group (FCE) no Georgia Institute of Technology da Universidade da Geórgia, em Atlanta, EUA, com o objetivo de desenvolver tecnologias de Computação Ubíqua para a vida cotidiana das pessoas. $\mathrm{O}$ FCE ficou mundialmente conhecido pela criação dos Living Laboratories, laboratórios de pesquisa que servem como ambientes-protótipos para o desenvolvimento de aplicações, dentre elas o Aware Home.

A Aware Home Research Initiative (AHRI) explora de forma multidisciplinar tecnologias e serviços emergentes para residências. Iniciada em 1998, é uma residência-laboratório de três andares, com aproximadamente $468 \mathrm{~m}^{2}$, onde já foram vários desenvolvidos projetos de rastreamento de objetos e pessoas como o Head Pose Tracking (RUDDARRAJU; HARO; ESSA, 2003), Frequently Lost Objects e o Smart Floor (ORR; ABOWD, 2000), computação vestível (Wearable Computing Project) e para a vida cotidiana no trabalho (Augmented Office) ou na sala de aula (Classroom 2000 e KidsRoom), (KIDD; ORR; ABOWD, 1999). 


\section{MIT House $\_n$ (MIT)}

O House_n é um projeto multidisciplinar criado pelos pesquisadores do departamento de arquitetura do Massachussetts Institute of Technology (MIT), nos EUA, com o objetivo de desenvolver soluções para o ramo da construção civil.

O MIT House_n em parceria com a empresa TIAX desenvolveram o PlaceLab, uma residência-laboratório de aproximadamente $92 \mathrm{~m}^{2}$ para desenvolver e testar novas tecnologias para o dia a dia.

O Open Source Building Alliance (OSBA) é uma iniciativa para aproximar o meio acadêmico da indústria para desenvolver estratégias e tecnologias para criar construções sustentáveis. Um dos principais aspectos a serem estudados é a forma como as casas são construídas parte por parte há anos. Um processo ineficiente que atrapalha o controle de qualidade do produto final, desperdício de material, grande quantidade de resíduos. The OPEN Prototype Initiative é uma iniciativa para desenvolver protótipos de casas para a construção em massa na tentativa de criar métodos de construção mais eficientes, menos nocivos ao meio ambiente e que possibilite a customização dos ambientes de uma forma semelhante à adotada nos processos industriais (OSBA, 2008).

\section{MavHome (University of Texas)}

O MavHome (Managing An Intelligent Versatile Home) é um projeto multidisciplinar da Universidade do Texas (Arlington, EUA) focado na criação de residências inteligentes. Sob o comando de Diane Cook e Sajal Das, dois especialistas em ambientes inteligentes, o MavHome é baseado em agentes distribuídos que gerenciam atuadores que alteram as condições físicas baseados nas informações provenientes de sensores, com o objetivo de maximizar o conforto e a produtividade de seus habitantes. Um dos estudos principais é a predição das ações dos usuários e o desenvolvimento de algoritmos de predição. Um sistema de monitoramento tridimensional foi criado para controlar e monitor as condições do ambiente remotamente (COOK et al., 2003).

\section{Duke Smart Home (Duke University)}

Em 2000, a Pratt Scholl of Engineering da Universidade de Duke na cidade Durham, Carolina do Norte (EUA) iniciou um plano multidisciplinar para estimular a cultura de desenvolvimento de novas tecnologias chamado Vision for 2010. Um dos projetos que nasceram dessa iniciativa foi o Duke DELTA Smart House Program para a construção de uma casa que servisse como laboratório criando oportunidades para alunos se engajarem em pesquisa e na criação de 
produtos para residências. Em 2003, sob o novo codinome de Duke Smart Home, o projeto começou a ser desenvolvido e iniciou-se a busca por patrocínio.

Em 2007, com o patrocínio de US\$ 2 milhões da empresa The Home Depot, uma das maiores varejistas americanas de material de construção, a casa de dois andares e aproximadamente $560 \mathrm{~m}^{2}$ começou a ser construída e atualmente abriga dez estudantes vivendo em período integral. A residência-laborátorio contempla diversos sistemas de controle e de energia desenvolvidos pelos alunos de engenharia e foi concebida com elementos ecológicos para demonstrar novas técnicas de construção sustentável e tecnologia residencial. A residência se chama agora The Home Depot Smart Home.

\section{The Interactive Workspace Project (Stanford University)}

O projeto Interactive Workspaces é uma iniciativa da Universidade de Stanford (EUA) e surgiu em 1999 como uma extensão de uma pesquisa que investigava o uso de grandes telas de alta resolução como interfaces. O potencial da interatividade dessas telas em ambientes inteligentes se tornou claro, mas ainda havia a necessidade de se criar aplicações que envolvessem seu uso em conjunto com outros dispositivos eletrônicos.

Para isso, alguns protótipos de ambientes foram construídos para acomodarem as telas e prover um espaço para integrar todos os dispositivos em rede. Esses protótipos foram chamados de iRoom (Interactive Room)(FOX et al., 2000). Além de câmeras e microfones, a versão mais evoluída do iRoom apresenta diversas telas de alta definição presas às paredes funcionando como murais interativos e uma mesa com uma tela de toque embutida onde se desenvolvem encontros e reuniões.

A infraestrutura do iRoom é toda baseada em uma plataforma chamada iROS (Interactive Room Operating System) que provê os mecanismos necessários para o desenvolvimento de aplicações interativas em ambientes inteligentes.

\section{Aura (Carnegie Mellon)}

O projeto Aura da Universidade Carnegie Mellon cria um escudo entre o usuário e o ambiente pervasivo de modo que o usuário não seja distraído com problemas, detalhes técnicos, etc. Um dos problemas de Computação Ubíqua é que os recursos variam no tempo. Desta forma, conforme o nome do projeto já diz, existe uma aura que envolve o usuário e que gerencia essas questões com o ambiente. Dessa forma o usuário não se distrai e pode executar suas rotinas e tarefas diárias (GARLAN et al., 2002). 
O projeto Aura envolve o desenvolvimento de interfaces (vestíveis, PDAs, etc.), de camadas de software, sensoriamento de posição e dos usuários e a criação de aplicativos para gerenciar informações de contexto baseado nas informações de posição e ações dos usuários.

\section{Gator Tech Smart Home (University of Florida)}

A Gator Tech é uma residência-laboratório da Universidade da Flórida, EUA. A equipe desenvolveu uma arquitetura genérica para a criação de ambientes pervasivos chamada de Smart House in a Box que tem sido utilizada como referência para outros projetos. Baseada na plataforma Atlas, a residência é inteiramente monitorada por uma extensa rede de sensores sem fio com o objetivo de coletar dados sobre a movimentação dos usuários e suas interações com o ambiente para gerar informações de contexto e permitir que a casa modifique o estado de seus ambientes automaticamente.

\subsubsection{Iniciativas Corporativas}

\section{EasyLiving (Microsoft)}

O notável interesse de seu fundador, Bill Gates, pelo tema e o grande alvoroço provocado em 1995 pela construção de sua casa de 40 milhões de dólares, toda automatizada, despertaram o interesse da Microsoft em desenvolver plataformas para fomentar soluções sobre o tema casas inteligentes.

EasyLiving é um projeto da Microsoft Research, criado em 1997, para o desenvolvimento de ambientes interativos e tecnologias da casa do futuro. Sob a seção de Computação Ubíqua do Vision Group, o EasyLiving tem desenvolvido mecanismos que permitem o uso coerente de diversos dispositivos por parte do usuário.

Um dos motes do EasyLiving é a transformação do computador tradicional em diversos dispositivos distribuídos pela residência cientes da localização e dos atos dos usuários. Por meio de interfaces apropriadas, o usuário não teria que ir a um local específico para interagir com o computador, nem usar as interfaces mouse e teclado como acontece atualmente. Em qualquer lugar ele teria acesso às informações e serviços, bastando se comunicar por voz ou por gestos, de forma natural, com o sistema integrado à residência. Isso motivou o desenvolvimento de novas interfaces, modelagem geométrica do ambiente, métodos de rastreamento e percepção e técnicas de descrição e gerenciamento de serviços. 


\section{Philips Home Lab (Philips)}

O HomeLab faz parte de um processo de longo prazo iniciado pela Philips para desenvolver um novo conceito de produtos e soluções para casas do futuro. Em 1996, o departamento de design iniciou o projeto Vision of the Future para investigar as tecnologias que iriam ser desenvolvidas nos 10 anos seguintes. Depois de vários workshops, sessenta conceitos básicos foram desenvolvidos e publicados detalhando as possibilidades de como seriam o futuro das casas, viagens e até dos hospitais. Esse projeto foi responsável por disseminar uma cultura relacionada aos ambientes pervasivos de uma nova era que estava por vir e que necessitaria de produtos muitos mais amigáveis e fáceis de usar (AARTS, 2003).

Segundo Emile Aarts, pesquisador sênior da empresa e autor de vários trabalhos e livros sobre o assunto, a noção de ambientes inteligentes foi proposta dentro da empresa em 1998. Após quatro anos amadurecendo as propostas, o HomeLab foi inaugurado.

O HomeLab é uma casa real monitorada por câmeras e microfones escondidos e espelhos de duas faces permitindo que os pesquisadores possam observar o comportamento de pessoas vivendo suas rotinas diárias. Os pesquisadores da empresa acreditam que ela permite avaliar de um modo mais realístico e natural a forma como as pessoas interagem com tecnologia, capacitando-os a criar novas tecnologias e desenvolver produtos melhores.

Vários projetos têm sido desenvolvidos integrando um conjunto de tecnologias-protótipos de ambiente inteligente que são sensíveis, personalizáveis, adaptáveis e interativas.

O projeto DreamScream estuda a utilização de telas gigantes de alta resolução na criação de ambientes imersivos. O projeto InteractiveMirror utiliza espelhos comuns como displays para exibir informações sobre o clima, mensagens, etc. e como interfaces de toque para controlar dispositivos ou acessar a Internet. Outros aplicativos também utilizam o espelho do banheiro como interface como é o caso do Intelligent Personal Care Environment que exibe notícias para os adultos e desenhos infantis para encorajar as crianças a escovarem o dente pela manhã.

O projeto InteractiveToys utiliza o conceito de Computação Ubíqua para desenvolver jogos e aplicações de entretenimento. Como exemplo, o StoryToy, um aplicativo que conta histórias, o Splashball, um jogo de realidade virtual e o POGO, um jogo interativo que mescla fantasia com realidade e permite que as crianças possam compartilhar as mesmas brincadeiras e histórias.

O projeto PHENOM (Perceptive Home Environments) tem o objetivo de criar um ambiente em que o usuário seja capaz de interagir com os sistemas eletrônicos a sua volta de uma forma mais natural sem que haja a necessidade de se envolver com os aspectos da tecnologia. A capacidade do ambiente em identificar a posição e a intenção de cada morador dentro da casa 
permite desenvolver aplicações que reajam e até se antecipem às necessidades dos moradores. O primeiro protótipo criado pelo PHENOM foi um sistema móvel e sem fio para a visualização de álbuns de fotos. A escolha por esse protótipo como o inicial foi baseado em estudos que mostram que as pessoas são apegadas as suas memórias como fotos e objetos pessoais e isso facilita sua aproximação com o sistema e com a nova tecnologia. O projeto WWICE (Window on the World of Communication and Entertainment) gerencia as típicas atividades diárias em um único sistema. $\mathrm{O}$ ato de gravar um mensagem de voz, assistir um vídeo ou escutar música pode ser realizado de qualquer lugar da casa.

O HomeLab também contempla o estudo de agentes robóticos na vida cotidiana. Os robôs são uma categoria emergente de produtos que terão um papel importante nas residências inteligentes auxiliando as pessoas no acesso a dispositivos e serviços. No laboratório, uma demonstração do iCat, um mini robô em forma de gato, atua como um assistente pessoal na cozinha.

O HomeLab tem auxiliado os pesquisadores da Philips a desenvolverem uma linha de eletroeletrônicos sensíveis ao contexto. Os produtos da linha amBX, por exemplo, proporcionam uma experiência sensorial diferenciada alterando suas propriedades de acordo com o conteúdo multimídia apresentado. 


\section{Arquitetura de Sistemas para Residências Inteligentes}

\subsection{Introdução}

No início dos anos 1990, pesquisadores de todo o mundo, motivados pela Computação Ubíqua, começaram a propor novas arquiteturas de sistemas para o ambiente residencial.

Historicamente, a integração de equipamentos eletrônicos no ambiente residencial tem sido um processo manual. Como Helal et al. (2005) observam, inserir um novo elemento requer pesquisa de suas características e modo de operação, determinar como configurar e integrá-lo, e, repetidamente, testá-lo para evitar conflitos e comportamentos inesperados do sistema.

A Computação Ubíqua propunha resolver essa questão com dispositivos auto-configuráveis que estariam presentes em todos os lugares, ao redor das pessoas, interagindo a todo o momento, sem, no entanto, que fossem notados. Weiser e Brown (1997) definiram esse conceito como tecnologia calma (calm technology), que pode ser melhor interpretada como uma sugestão de como os desenvolvedores deveriam direcionar suas criações para que essa nova era da computação moderna amplificasse nossos mecanismos sensoriais e o nosso poder de interação com o ambiente sem que a imensa quantidade de informação ao nosso redor nos paralisasse totalmente.

Dentre as inúmeras arquiteturas que surgiram nos moldes da Computação Ubíqua, pode-se destacar MavHome (COOK et al., 2003), Atlas (HELAL et al., 2007) e Aura (GARLAN et al., 2002). Embora apresentem expressivas diferenças entre si, elas se assemelham pelo fato de serem arquiteturas para uso genérico. Muitas vezes aplicações bem definidas motivam o desenvolvimento de toda a tecnologia de suporte. Por exemplo, as mini-câmeras e as placas captadoras de imagem evoluíram com a demanda do mercado por sistemas de segurança patrimonial. Mas isso não tem acontecido na mesma proporção com os ambientes inteligentes.

Os pesquisadores e fabricantes têm se beneficiado com a redução de custo e tamanho dos componentes eletrônicos, e com o crescimento e facilidade de troca de dados em redes de comunicação. Mas há vinte anos e, certamente, ainda nos dias atuais, a falta de uma aplicação, e conseqüentemente, a falta de demanda do mercado explicam o aparecimento dessas arquiteturas genéricas. A motivação inicial de tornar os ambientes inteligentes ainda se mantém e o contexto socioeconômico do século XXI, conforme observado no Cap. 2, vem se demonstrando 
propício para o desenvolvimento dessas arquiteturas, que em breve, darão suporte tecnológico a aplicações comerciais.

\subsection{Cenário}

A criação de um cenário residencial ajuda a identificar as necessidades e as oportunidades de aplicações.

Marcos e Joana são casados há 25 anos e têm dois filhos, Bruno e Cristina, com idades de 19 e 22 anos, respectivamente. Marcos é engenheiro e Joana, publicitária. Ambos passam o dia trabalhando fora. Bruno está no primeiro ano da faculdade de Direito e às vezes tem algumas tardes livres. Cristina é comissária de bordo e, na maioria das vezes, está viajando.

Casal jovem com filhos em idade universitária. Grande possibilidade de aceitação de novas tecnologias, acesso à Internet, redes sociais e jogos. Necessidade de sistema de segurança e de monitoramento remoto.

Eles moram em uma casa de três dormitórios, sendo o do casal uma suíte.

Família pertencente à classe A ou B, que contam com disponibilidade financeira.

Há aproximadamente um ano, a mãe de Joana, dona Maria, uma senhora de 80 anos, foi diagnosticada com o mau de Alzheimer.

Possível dificuldade na aceitação de novas tecnologias. Necessidade de monitoramento.

O médico explicou para a família como a doença iria progressivamente abalar suas faculdades mentais e sugeriu que ela tivesse um acompanhamento mais intenso. Joana resolveu convidá-la para morar em sua casa para facilitar o tratamento de Dona Maria.

Tecnologia adaptável, fácil de configurar.

A casa necessitou de uma reforma para acomodar com conforto a nova moradora, e um novo quarto e banheiro foram construídos.

Ocasião para equipamentos de baixo custo e de fácil e rápida instalação. Preferência por equipamentos modulares e sem fio, padronizados para garantir compatibilidade com equipamentos de outros fabricantes e aquisições futuras.

A empregada da casa foi instruída para monitorá-la à distância.

Possibilidade de pessoas sem formação técnica especializada. Equipamentos com interfaces amigáveis, fáceis de operar, monitorados à distância. 
No início, dona Maria começou a ter pequenos lapsos de memória e algumas vezes se esquecia de apagar a luz do seu quarto quando saía e outras vezes a chuva molhou o cômodo por ter deixado a janela aberta.

Sensoriamento de condições climáticas externas à residência. Controle automático de janelas e sistemas de iluminação.

Com o progressivo agravamento da doença, a memória e o discernimento de dona Maria começaram a colocar sua vida em perigo. Seus medicamentos começaram a sobrar no fim do mês, indicando que ela se esquecia de tomá-los.

Sistema de comunicação por voz e vídeo com equipe remota de saúde e familiares. Sistema de agendamento de tarefas com aviso luminoso e sonoro de eventos.

Uma vez ela abriu o portão automático da garagem com o controle remoto e saiu para a rua. Felizmente, o vizinho a viu e a encaminhou de volta à residência.

Sistema de controle de acesso, identificação de usuário.

Dona de casa exemplar, ultimamente ela vinha apresentando queimaduras nas mãos por usar o fogão para aquecer seu chá. Ela dizia que não sabia mais usar o forno de microondas porque seus botões eram muito pequenos e que a deixavam confusa.

Interfaces simples, adaptativa às necessidades do usuário.

Um dia ela esqueceu a panela no fogo aceso por horas e quase colocou fogo na casa.

Detecção e controle automático de contextos indevidos. Encaminhamento de mensagens de aviso remotas. Política de contenção de incêndio e evacuação.

O quadro da doença vem se complicando e foi sugerido à família que contratasse uma enfermeira para acompanhá-la a todo o momento porque dona Maria não é mais capaz de viver sem um rígido controle.

Novo usuário na casa, auto configuração, auto adaptação. Controle restrito de acesso a determinadas áreas da residência.

Um sistema de monitoramento com botão de pânico foi instalado na casa, mas algumas vezes, a enfermeira a encontrou caída no banheiro, quase inconsciente devido à baixa pressão arterial.

Necessidade de utilização de sistemas integrados. Monitoramento contínuo de funções corporais, monitoramento de queda. Sistema de rastreamento, sistema de aviso com prioridade (primeiro a enfermeira, depois Joana e Marcos). 
Quando lhe perguntaram por que ela não havia apertado o botão de pânico, ela respondeu que não entendia para que servia aquele botão e que não se lembrou de apertá-lo. Uma vez ela confessou que sentia medo dele.

Sistemas automáticos que agem independentemente da vontade do usuário. Registro e armazenamento de todas as ações para futura análise.

\subsection{Descrição Funcional}

Observando-se a Figura 4, que exibe a arquitetura simplificada em blocos, pode-se notar que a percepção do ambiente é um processo que ocorre da esquerda para a direita. Sensores monitoram o ambiente (e.g., temperatura da sala), seus dados são digitalizados e enviados (nós de controle) via rede doméstica para serem analisados pelos sistemas de alto nível (gerenciador residencial). A ação é um processo que ocorre na direção inversa. Os sistemas de controle tomam decisões e enviam comandos para os atuadores modificarem o ambiente.

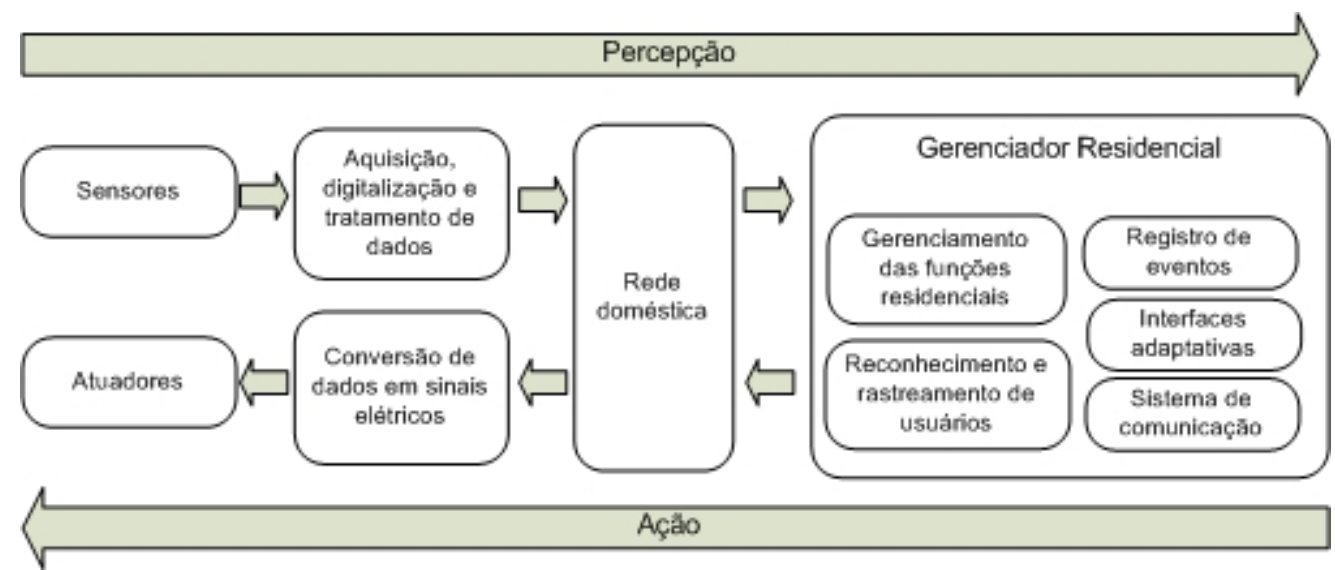

Figura 4: Diagrama simplificado da arquitetura

\subsection{Camada Física}

A camada física agrega todos os dispositivos físicos como sensores (temperatura, luminosidade, umidade, etc.) e atuadores (motores, solenóides, etc.). Nessa camada ocorre a conversão de fenômenos físico-químicos em sinais elétricos e vice versa.

Em meados da década de 1980, época em que se iniciou a introdução maciça de semicondutores em eletrodomésticos, surgiram vários equipamentos dotados de sensores e processadores que prometiam facilitar as tarefas residenciais. Fletcher (1985) descreve um forno da Panasonic que não dispunha de botões de ajuste de tempo ou temperatura para cozinhar. Bastava ligá-lo 
que, por meio de sensores de temperatura, umidade e até de peso, o forno sabia quando a comida estava pronta.

Segundo Horgan (1985), sensores de vibração, magnéticos e infravermelhos eram instalados por toda a casa para detectar invasores. Fischetti, Horgan e Wallich (1985) descreve o uso de sensores em sistemas residenciais de climatização.

O custo desses transdutores, porém, inibiu a fabricação desses eletrodomésticos e, atualmente, apesar de muitos equipamentos trazerem internamente sensores e atuadores, seu uso sempre foi moderado se comparado com a empolgação daquela época. O interessante é que o mercado de eletrodomésticos, de equipamentos independentes e de funções específicas, não despertou nos fabricantes a possibilidade do uso da fusão de sensores como fonte de informação para tomadas de decisão.

Atualmente, o alto custo desses transdutores ainda é um fator crítico nos desenvolvimento de sistemas eletrônicos. Mesmo com o avanço da ciência de materiais e semicondutores, ele ultrapassa os gastos com processamento, fonte de alimentação e sistema de comunicação em um nó de controle.

\subsection{Camada de Interface de Transdutores}

A camada de interface de transdutores é responsável por converter sinais elétricos, disponibilizar mecanismos de acesso ao transdutor e ao seu conjunto de informações e características. No caso de um sensor, ela converte os sinais analógicos em códigos digitais e disponibiliza o acesso às suas características e a como tratar seus dados. No caso de um atuador, essa camada disponibiliza o acesso às suas características e converte os códigos digitais em sinais analógicos para efetuar seu controle.

Essa camada se comunica com dispositivos de rede que transmitem as informações dos transdutores representadas de uma forma conveniente e uniforme para o resto da arquitetura. No entanto, a demora na definição de um padrão aberto para os barramentos e redes de controle obrigou os fabricantes a desenvolverem soluções próprias para cada rede existente, resultando em diversas especificações.

As normas IEEE1451 (IEEE, 1999) procuram atenuar o problema propondo padrões para as interfaces entre os transdutores e a rede de controle sem alterar as tecnologias existentes ou impor uma nova especificação de rede de controle. Essa é uma iniciativa do Institute of Electrical and Electronics Engineers (IEEE) junto com o National Institute of Standards and Technology (NIST) e representantes da indústria que têm proposto um conjunto padrão de mensagens e des- 
crições de sensores e atuadores para ser utilizado desde o transdutor até a troca de dados pela rede de comunicação. Segundo Johnson (1997), o intuito é permitir a separação entre a escolha dos transdutores e a escolha da rede de controle por meio da implementação de um conjunto de interfaces comuns entre eles. Por meio destas interfaces padronizadas, os transdutores podem ser conectados às diversas redes de controle já disponíveis, tornando-se intercambiáveis e interoperáveis.

Atualmente, um nó de controle é capaz de gerenciar um ou mais transdutores. A principal característica de um transdutor é seu valor presente. Ele pode corresponder a um aspecto do mundo real (a temperatura de um quarto ou o estado de uma chave) ou ter uma natureza mais abstrata (ser a referência de uma temperatura). Mas como seu valor é representado digitalmente (inteiro, ponto flutuante, booleano, etc.), para qualificá-lo são associados atributos adicionais (ou meta-informações, segundo Zimmer (2004)) que são importantes no contexto da aplicação de controle.

Esses atributos adicionam um significado semântico ao valor do transdutor e também são usados para garantir compatibilidade entre os diversos transdutores. Um atributo de precisão especifica o menor incremento que pode ser representado. Atributos como valor mínimo, valor máximo e resolução descrevem o raio de observação do transdutor.

Dentro da família de normas IEEE1451, a padronização do Transducer Electronic Data Sheet (TEDS) é uma das questões abordadas (IEEE, 1998). O TEDS é uma documentação eletrônica que fica armazenada em uma memória não-volátil, próxima ao transdutor, contendo informações descritivas e tem como finalidade proporcionar funcionalidades plug and play ao dispositivo. Em outras palavras, o TEDS é uma iniciativa de padronização das meta-informações e evita complicações adicionais ao sistema (Figura 5).

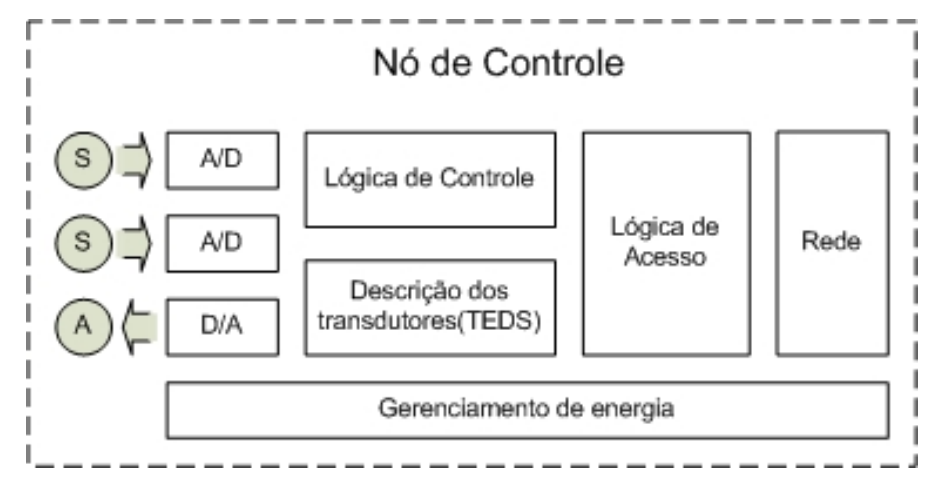

Figura 5: Diagrama de componentes do nó de controle 


\subsection{Camada de Comunicação}

Ricquebourg et al. (2006) sugerem duas necessidades primordiais que a camada de comunicação deve satisfazer: tornar possível a comunicação entre os diversos dispositivos e equipamentos; e conectar a casa ao mundo externo. Cook et al. (2003) adicionam mais uma necessidade: a conexão entre a casa e os usuários.

Essa camada é responsável em prover um mecanismo que, adequadamente, formate, roteie e transporte informações internamente e externamente à casa. A Figura 6 exibe cinco diferentes tipos de redes. As duas primeiras, as WANs (Wide Area Networks) e MANs (Metropolitan Area Networks) são redes externas e servem a grandes áreas geográficas. Para as WANS são utilizadas tecnologia como SONET/SDH, ATM, Frame Relay ou tecnologias de satélite. Para as MANs, o ATM, FDDI, DQDB e SMDS, no entanto, essas tecnologias estão sendo substituídas pelas Gigabit Ethernet, 10 Gigabit Ethernet ou WIMAX.

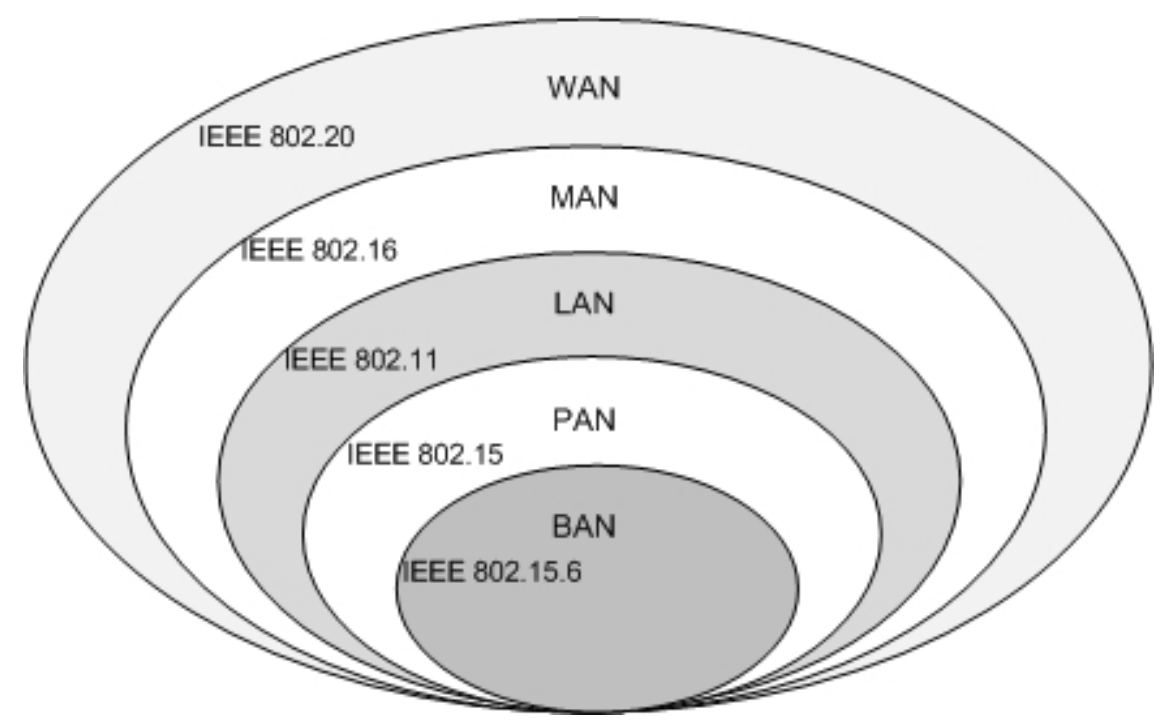

Figura 6: Modelos de redes de comunicação

Para o uso interno, as LANs (Local Area Networks), PANs (Personal Area Networks) e BANs (Body Area Networks). O Ethernet e o WiFi são as principais soluções, com e sem fio, respectivamente, para as LANs. Bluetooth, ZigBee e Z-Wave são tecnologias sem fio para as PANs. HomePlug e LonWorks são alguns exemplos de soluções cabeadas. Existem algumas redes ainda experimentais para as BANs que utilizam a pele ou a roupa como meio para transmitir dados. As aplicações esperadas para elas estão relacionadas à saúde como o monitoramento de sinais vitais, como proposta por Jovanov et al. (2005).

Em uma situação ideal a camada de comunicação deveria ser transparente para o desenvolvedor da aplicação. Em outras palavras, o modo como os dados são enviados e recebidos 
pelos nós de controle não deveria influenciar no processo de desenvolvimento das aplicações em uma residência inteligente. A divisão das responsabilidades em camadas verticais, como proposta por vários autores (e.g. (HELAL et al., 2005), (ROMAN C.H., 2002) e (COOK et al., 2003)), visa facilitar a identificação das funções que cada camada deve realizar antes que a informação passe adiante. Porém, segundo Bush, Griffin e Meyer (2002), isso implica também que a otimização de cada camada deve ser feita separadamente, escondendo informações vitais que poderiam ser úteis para as outras camadas.

Na prática, esse efeito se estende a todas as outras camadas e significa que as idiossincrasias do sistema, de fato, influenciam a criação das aplicações. A histerese e a velocidade de mudanças dos transdutores, a indisponibilidade dos nós de controle devido ao rígido gerenciamento de energia, e os atrasos associados a cada evento devido à velocidade da rede de comunicação são alguns exemplos dessas peculiaridades - não explicitamente declaradas - do sistema que devem ser consideradas pelo desenvolvedor da aplicação.

O ZigBee e HomePlug são dois exemplos de redes PAN sem fio que nasceram para o mercado de automação residencial. O ZigBee utiliza um mecanismo de transmissão por radiofreqüência e um protocolo de comunicação que evidencia a economia de energia. O HomePlug utiliza a tecnologia de envio de pacotes pela rede elétrica (PLC - Power Line Communication) e alcança taxas de até $14 \mathrm{Mbps}$ (HOMEPLUG, 2007). As duas entidades que controlam o desenvolvimento dessas redes, a ZigBee Alliance e a HomePlug Powerline Alliance, têm unido esforços para criar soluções integradas e expandir o mercado de redes domésticas. Apesar de competirem no mesmo mercado, foi observado que em muitas ocasiões elas podem ser implantadas como soluções complementares.

\subsubsection{Gateways}

O gateway residencial é o dispositivo que conecta a rede interna à rede externa. Ele permite que as aplicações domésticas acessem serviços e informações de provedores externos e que seja possível controlar a casa remotamente. O gateway se tornou um dispositivo estratégico no mercado de redes e de serviços residenciais porque, além de desempenhar suas funções elétricas, conectando diferentes meios, ele tem sido usado como portal eletrônico de informação, entretenimento e serviços restritos a assinantes. 


\subsection{Camada de Interface Computacional}

Cook et al. (2003) se utilizam de uma camada chamada Interface Computacional para descrever as interfaces que conectam e transformam entidades da camada física em entidades lógicas. Nessa camada são descritas as interfaces PCI, USB, Firewire, etc. e todo o software que permite o seu acesso pelas camadas superiores. Essa camada se faz necessária porque o computador agrega múltiplas interfaces e muitos fabricantes se beneficiam delas como meio para interligar seus produtos e oferecer serviços. No entanto, a camada de interface computacional, necessariamente, não engloba as camadas responsáveis pelos transdutores (física, interface de transdutores e de comunicação). O fato é que a arquitetura dos nós de controle apresenta distinções importantes para incorporá-la na mesma camada das interfaces computacionais. Apesar de existirem semelhanças nas funcionalidades elétricas e lógicas, a crescente complexidade que tem envolvido os nós de controle, certamente, permite mantê-los em camadas distintas das camadas computacionais notoriamente já estabelecidas e conhecidas.

\subsection{Camada de Serviço}

Representa no mundo lógico as capacidades oferecidas pelo mundo físico. Cada sensor ou atuador conectado a um nó de controle tem sua representação lógica disponibilizada para as outras camadas por meio de um serviço.

Ela é responsável por manter a integridade dos serviços, adicioná-los e removê-los. Ela deve também oferecer um mecanismo de registro, identificação e busca de serviços para que as outras camadas possam saber quais serviços estão disponíveis e como utilizá-los.

Serviços complexos podem se utilizar de serviços mais simples que forneçam dados ou manipulem entidades. Desenvolvedores de aplicação podem criar serviços compostos usando esses mecanismos de busca para procurar por serviços existentes e usá-los para compor novos serviços.

Helal et al. (2005) recomendam que um conjunto de serviços padrões possa estar disponível para aumentar a produtividade dos desenvolvedores de aplicação. Tais serviços podem ser acessados por meio de uma interface de programação e incluir operações básicas como leitura, tradução e armazenamento de dados, agendamento de eventos, gerenciamento de entidades, entre outros.

É importante salientar que algumas arquiteturas propostas na literatura (e.g. King et al. (2006), Ricquebourg et al. (2006)) utilizam a camada de serviço como repositório de serviços de 
controle da residência. Para prover o controle de climatização, por exemplo, um serviço obtém os dados dos sensores de temperatura e umidade, e aciona o aquecedor ou ar-condicionado baseado em um algoritmo pré-definido, também denominado de serviço.

Além do fato desse modelo ter uma aceitação mais ampla, uma vez que os programadores são mais habituados a esse paradigma, Yang, Jansen e Helal (2006) ressaltam que ele permite um controle mais refinado das ações da casa inteligente, pois tem acesso direto às informações fornecidas pelos nós de controle. Esse modelo age proativamente gerenciando e interagindo com o ambiente, provendo serviços e não esperando passivamente até que o ambiente mude de contexto e depois reaja.

De fato, a manipulação de dados dos sensores e atuadores é efetuada diretamente sem a necessidade de conversores de linguagem, o que facilita o tratamento e o armazenamento de informações. Porém, desempenhar as funções de controle em uma camada de baixo nível, próxima dos nós de controle, cria uma série de problemas. Inicialmente, se observa um aumento significativo do número de serviços o que dificulta o seu gerenciamento. Aumenta também a possibilidade de riscos de segurança, uma vez que serviços de terceiros têm acesso direto aos nós de controle. Por fim, arquiteturas desse tipo podem restringir o fluxo de informações que seriam encaminhadas para as camadas superiores limitando as ações tomadas por sistemas de mais alto nível.

A arquitetura proposta neste trabalho sugere que os sistemas de controle sejam os responsáveis por efetuar uma análise conjunta das informações disponibilizadas pela camada de contexto e pela camada de serviços, e arbitrar sobre a ação a ser tomada.

\subsection{Camada de Contexto}

O modelo orientado ao contexto representa cada estado da casa baseado em combinações dos estados dos sensores e o classifica de acordo com uma lógica pré-definida. Uma das maiores vantagens do contexto é o alto nível de explicitação. Descrevendo os possíveis contextos de uma casa inteligente, pode-se identificar, indubitavelmente, que contexto está correntemente ativo. Definindo ações baseadas nos contextos ativos, o comportamento do sistema é explícito, em contraste com as chamadas de funções da programação tradicional orientada ao serviço. Essa habilidade de abstrair dados e disparar ações, que correspondam a essas descrições de alto nível, tem suma importância porque o estado em que se encontra a casa, como por exemplo, frio, quente ou úmido, tem significado para seus residentes.

Geralmente, os sensores são designados para detectar um particular valor em um amplo 
domínio. Trabalhar com todas as combinações de valores possíveis dificulta o processo de análise e a criação de algoritmos de controle. Associar ações com a abstração dos valores facilita todo o processo e permite estender a informação a outros contextos.

Cada contexto pode ser usado para determinar o estado em que a residência se encontra e para acionar ou restringir um serviço. Pode também especificar que estados um espaço ou uma entidade pode ou não entrar.

No caso dos atuadores, eles têm um efeito intencional em um domínio. Por exemplo, o efeito de se ligar um aquecedor é aumentar a temperatura. Dada essa descrição, é possível determinar quais estados são aceitáveis a partir do estado corrente e identificar quais efeitos intencionais são mutuamente exclusivos. Isso garante, por exemplo, que o ar-condicionado e o aquecedor nunca serão acionados simultaneamente, ainda que ambos tenham por propósito ajustar a temperatura.

Idealmente, se um ambiente inteligente entra em um contexto não permitido ele deve tentar sair dele sem intervenção humana. Como é possível mapear os atuadores que correspondem a um determinado contexto, a identificação de contextos não desejáveis e de comportamentos contraditórios é facilitada. O sistema deve invocar os atuadores baseados na informação do estado para automaticamente corrigir os problemas. Dentre suas responsabilidades, a camada de gerenciamento de contexto deve permitir que desenvolvedores criem e registrem contextos de interesse, e provenha um mecanismo que monitore e gerencie os contextos correntes.

\subsection{Camada de Conhecimento}

Uma residência inteligente deve ser capaz de observar o comportamento dos dispositivos eletrônicos e de seus moradores para oferecer-lhes o serviço mais adequado àquela ocasião. Por meio da camada de conhecimento é possível adicionar, remover e gerenciar algoritmos capazes de analisar seqüências de eventos e identificar padrões para auxiliar a camada de decisão na seleção das ações a serem tomadas.

A chave do processo está em modelar computacionalmente o mundo externo de uma forma apropriada para que os sistemas de controle possam utilizar essas informações para inferir sobre a melhor decisão a ser tomada. Tipicamente, uma rede de sensores é usada para coletar essa informação em tempo real. Os eventos gerados pelos transdutores e pelas interações dos moradores com a residência são, tipicamente, uma tripla que consiste de três informações básicas: a identificação do dispositivo que gerou o evento, seu valor e o horário que o evento ocorreu. Em uma primeira instância, a seqüência desses eventos é avaliada para se detectar padrões 
que possam corresponder a atividades. Se a residência inteligente for capaz de identificar tais atividades e a periodicidade com que elas ocorrem, ela pode entender como os usuários e os próprios sistemas de controles se comportam, aprendendo, dessa forma, a selecionar, de forma mais apropriada, as ações a serem tomadas.

É como se existisse um mordomo virtual, um “observador invisível”, na descrição de Pentland (1998), que, baseando-se no histórico das suas ações e das interações dos usuários, ele estaria, continuamente, aprendendo a sugerir o melhor conjunto de serviços e a melhor configuração dos sistemas da residência para satisfazer as necessidades e vontades do seu morador.

\subsection{Camada de Decisão}

A camada de decisão seleciona as ações que devem ser tomadas baseadas nas informações fornecidas pelas outras camadas. Cada ação corresponde a um conjunto de mudanças no estado dos atuadores, refletindo diretamente no comportamento da residência inteligente.

A qualidade de um algoritmo de decisão está em escolher a melhor opção dentre um domínio de possibilidades que satisfaça as vontades e as necessidades de conforto e segurança dos moradores. Porém, a dificuldade reside no fato que a escolha da melhor opção, geralmente, não depende apenas do estado atual que a casa se encontra, mas também do histórico das atividades do usuário e dos próprios sistemas de controle. A grande influência dessa camada na qualidade de vida dos moradores aumenta também sua responsabilidade no sucesso das residências inteligentes. E não é por acaso que muitos autores se dedicam a criar e testar algoritmos de decisão.

Segundo Bigus e Bigus (2001), regras do tipo se-então são uma forma bem popular de representação de conhecimento usada em aplicações de Inteligência Artificial. Um dos motivos é que é confortável para as pessoas ler regras do tipo:

Regra 01: se temperatura da sala $<26^{\circ} \mathrm{C}$ então ligar o ar-condicionado

No entanto, os autores salientam que à medida que o número de regras cresce tanto o aspecto intuitivo quanto a facilidade de leitura são prejudicados. Outro fator é que, em uma residência, a quantidade de regras pode ser tão elevada que é difícil construir mecanismos para validá-las, detectar anomalias, ou mesmo verificar se elas estão atendendo às necessidades da casa e do usuário.

Outro problema em sistemas desse tipo é a capacidade limitada de adaptação a novas informações. Por exemplo, se a grama está molhada o sistema pode inferir que está chovendo. Mas, 
caso haja a informação de que o equipamento de irrigação do jardim está ligado, então o sistema deve reavaliar o fato e retratar sua conclusão, ou pelo menos reduzir o nível de confiança nela. Com o propósito de manter os estados consistentes, essa reavaliação requer uma manutenção constante na estrutura da base de dados de conhecimento.

Alguns autores desenvolveram mecanismos de decisão mais elaborados e específicos para aplicações em residências inteligentes. Youngblood, Holder e Cook (2005), por exemplo, descrevem o ProPHeT, um algoritmo que observa a seqüência histórica de eventos e, auxiliado por um preditor, consegue estimar qual ação terá mais utilidade naquele momento. Mozer (1998) e Chan et al. (1995) descrevem o uso de redes neurais artificiais pró-alimentadas e com propagação de erro para controlar o funcionamento de eletrodomésticos. Stankovski e Trnkoczy (2006) demonstram alguns exemplos de uso de árvores de decisão na análise de eventos em ambientes inteligentes.

Bolzani (2004b) sugere que a responsabilidade pelo processo decisório seja divido por 14 sistemas de controle, organizando, desta forma, o domínio de atuação e as responsabilidades de cada um (Tabela 2).

\section{Sistemas}

Fluidos e detritos

Ventilação, aquecimento e ar condicionado

Redes de computadores

Detecção e combate de incêndios

Controle e automação de acessos

Detecção e controle mecânico

Auditoria e otimização de processos
Energia elétrica

Iluminação

Segurança

Telefonia

Áudio e vídeo

Monitoramento e visualização

Rastreamento e percepção

Tabela 2: Sistemas de controle

A subdivisão em vários sistemas de controle tem também o objetivo de facilitar a implantação de algoritmos de terceiros para o controle de seus equipamentos em uma residência inteligente. No entanto, como esses sistemas manipulam diretamente o estado dos atuadores, o funcionamento da residência fica susceptível a problemas de conflito, falhas de segurança e algoritmos mal intencionados. Os conflitos ocorrem quando os sistemas de controle decidem por 
ações que deixam o atuador em um estado incompatível. Por exemplo, o sistema de segurança tem como objetivo manter a casa segura, mantendo fechadas as portas e janelas, e o sistema de climatização quer abrir as janelas para aumentar a ventilação. Isso pode acontecer porque na arquitetura proposta os sistemas de controle serão criados por diferentes fabricantes e atuarão de forma independente. A primeira vez que trabalharão em conjunto é quando forem instalados na residência.

Assim, é necessária a criação de um agente moderador, um árbitro, que defina prioridades caso haja conflitos, que estabeleça políticas de segurança para evitar riscos, ou mesmo imponha regras básicas estipuladas pelos moradores que nunca devem ser violadas.

\subsection{Camada de Aplicação}

O objetivo dessa camada é disponibilizar ferramentas para que desenvolvedores criem e registrem suas aplicações. Ela deve prover um ciclo de desenvolvimento, incluindo as fases de programação, simulação, instalação, teste, depuração e implementação. Toda a informação proveniente das outras camadas faz com que a programação seja focada no comportamento da casa e não em detalhes técnicos de sensores, agentes, etc.

Uma vez que os sensores, atuadores e dispositivos inteligentes estão conectados à rede de controle, a arquitetura deve prover informação sobre a capacidade dessas entidades e dos seus serviços disponíveis para que o desenvolvedor seja capaz de programar o ambiente especificando como deseja que cada entidade se comporte.

Os efeitos da introdução, alteração ou remoção de entidades ou serviços devem se refletir nessa camada e a aplicação deve estar ciente dessas modificações. A interoperabilidade é um dos maiores desafios na construção de ambientes inteligentes. Constantemente novas entidades são introduzidas e outras, retiradas ou não utilizadas. A aplicação deve suportar esse dinamismo e tentar contornar um eventual problema para que a residência inteligente não atinja um estado indesejado colocando em risco a segurança e o conforto de seus moradores.

\subsection{Interfaces com o Usuário}

Mozer (2005) exibe vários relatos de pessoas que tiveram problemas de adaptação com novas interfaces e com sistemas de controle residenciais com alto nível de sofisticação. Segundo ele, parece que existe a intenção de complicar as tarefas que, historicamente, sempre foram simples como acionar um interruptor para acender uma lâmpada. Em seus argumentos, as casas 
inteligentes falharam em se tornar uma realidade por duas razões: primeiro, porque acredita que os moradores estão satisfeitos com os controles tradicionais; e é grande o obstáculo para entender as novas interfaces. Para ele, a "tecnologia será adotada se o retorno compensar o esforço para entender a nova tecnologia".

Se analisarmos a residência nos moldes da década de 1960, com a dona de casa responsável pela administração do lar, cuidando da limpeza, permanecendo praticamente todo o dia dentro da casa monitorando os filhos, e em um contexto socioeconômico do pós-guerra que enfatizava o consumo e a abundância, o uso de sistemas de controle e de interfaces complexas realmente não se fazia necessário.

No entanto, no contexto mundial do século XXI, abordado no Cap. 2, é totalmente plausível considerar a automação residencial como um conjunto de ferramentas para prover um maior bem estar aos moradores da casa inteligente com o mínimo impacto energético. Dentre essas ferramentas, as interfaces desempenham um papel importante facilitando a interação entre a casa e os que nela convivem. Além das interfaces comuns como teclas, botões, dispositivos rotativos e deslizantes, as telas de toque, comandos por voz e o uso de gestos e expressões faciais são exemplos de interfaces avançadas que amplificam as interações dos moradores com a residência e provêem auxílio especial a idosos, crianças e pessoas com deficiência.

\subsection{Sistemas Centralizados $x$ Descentralizados}

$\mathrm{Na}$ arquitetura descrita, toda a análise de alto nível, tanto a realizada pelos sistemas de controle como pelos geradores de contexto, é centralizada em um só ponto que detém o conhecimento de tudo que acontece na casa.

Essa abordagem facilita o processo de desenvolvimento dos algoritmos, de maneira geral, uma vez que os dados recebidos dos sensores estão todos disponíveis em um só local, a todo o momento. No entanto, sua principal fraqueza se torna evidente quando a comunicação entre os nós de controle e os demais sistemas é interrompida: a casa fica totalmente inoperante.

Nessa situação, uma solução seria programar o nó para que entre em modo de segurança e mantenha a residência operacional. Como a comunicação é realizada apenas entre os nós de controle, sem troca de dados externa, as operações de cada nó seriam restritas às funcionalidades descritas nas tabelas de gerenciamento, armazenadas em nós especialmente designados para esse fim (nó Coordinator na Figura 7).

O protocolo ZigBee, por exemplo, mantém essas tabelas armazenadas nos nós que exercem a coordenação da rede e que são alimentados continuamente, não por baterias, e, teoricamente, 


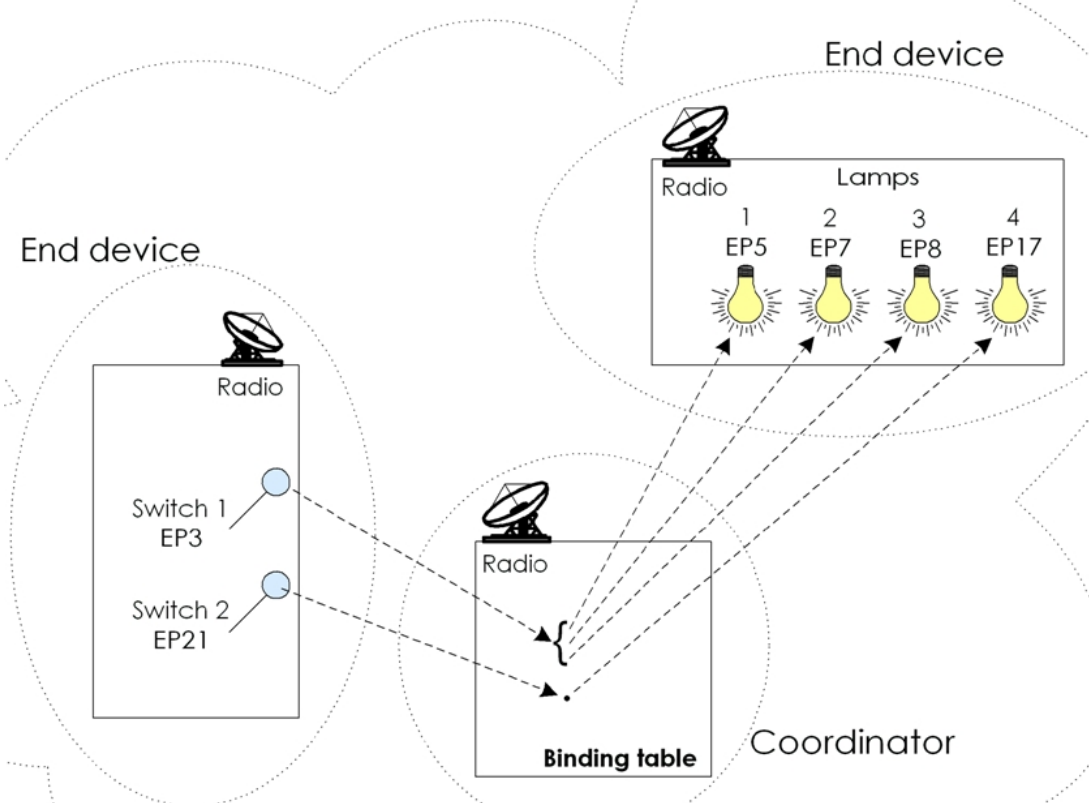

Figura 7: Estrutura de clusters ZigBee (Munk-Stander M.S. (2005))

sempre estão disponíveis. Ele as utiliza em seu regime normal de operação, pois o protocolo não fica à espera de comandos de sistemas de controle externos, mas o exemplo das tabelas pode ser usado na arquitetura proposta em caso de falha na comunicação com o servidor de aplicação (ZIGBEE, 2008).

Essas tabelas têm o intuito de manter a residência habitável até que a comunicação seja restabelecida, mantendo em operação um conjunto de funções que os moradores podem escolher como imprescindíveis ao seu dia a dia como, talvez, a detecção de incêndio, iluminação, controle de portas, etc. Outros equipamentos de uso secundário podem usar o modo seguro para garantir acesso aos seus comandos básicos como ligar, desligar ou alterar o ponto de funcionamento por meio de uma interface local.

A questão principal que está por trás dessas falhas é o balanço entre uma arquitetura centralizada e distribuída. Os dispositivos devem interagir para prover auxílio às atividades dos moradores, mas ao mesmo tempo eles devem ser capazes de tomar algumas medidas autonomamente. Locatelli e Vizzari (2007) sugerem um dispositivo que faça parte de um sistema e seja capaz de perceber o contexto local, detectar fontes relevantes de informações, comunicar sua presença e interagir com os demais. Mas, não é trivial delegar aos nós de controle todo o processo de análise de contexto. Uma das principais causas é a restrição imposta pelo hardware. Nos casos em que os nós são alimentados por baterias há a necessidade de um esquema rigoroso de gerenciamento de energia para estender ao máximo a carga disponível, o que, muitas vezes, implica na redução do tempo que o nó se mantém ativo. 
Apesar dos crescentes avanços na velocidade de processamento e quantidade de memória, o poder computacional desses nós ainda não é suficiente para suportar a complexidade dos algoritmos geradores de contexto, nem para armazenar toda a informação produzida.

O MICA, por exemplo, é um dos mais famosos nós de controle do mercado, comercializado pela empresa Crossbow Technology (XBOW, 2002). Baseado nos nós desenvolvidos na Universidade da Califórnia em Berkeley (HILL, 2002), eles vêm equipados com um processador de $4 \mathrm{MHz}$, com 4 kBytes de memória volátil e 128 kBytes de memória não volátil. O JStamp é um modelo mais recente, com um processador de 32 bits, $74 \mathrm{MHz}$ e 2MBytes de memória não volátil. Talvez seu maior benefício seja a possibilidade de executar programas diretamente na linguagem Java sem a necessidade de prévia tradução. Seu maior problema é o consumo de energia. Segundo o fabricante, uma bateria comum de 9V consegue manter o JStamp funcionando por apenas 24 horas, rodando a um décimo da freqüência máxima, ou seja $7.4 \mathrm{MHz}$ (SYSTRONIX, 2005).

Nas aplicações domésticas, o problema da energia poderia ser compensado conectando-se os nós à rede de distribuição elétrica, considerando que, raramente, um nó que controle a iluminação ou uma persiana teria seu local de instalação alterado. Nesse caso, um processador mais potente e maior quantidade de memória poderiam ser empregados. Mas, ainda assim, sem considerar o alto custo dessa solução como um ponto crítico, a própria natureza descentralizada dos eventos é um forte indício da dificuldade em manter todos os nós cientes de todos os processos que ocorrem na residência. Tecnicamente, não é impossível que cada evento gerado em um nó seja replicado para todos os outros. Mas, quaisquer que sejam as ações tomadas nesse nó, elas deverão também ser replicadas. Além de gerar um aumento substancial da atividade da rede de comunicação, é grande a possibilidade de haver discrepâncias entre os estados armazenados em cada nó devido a dados corrompidos.

Uma solução intermediária entre a arquitetura totalmente centralizada e a distribuída é identificar um conjunto de informações elegíveis que pode ser difundido entre os nós, segundo regras específicas que gerenciem sua distribuição através dos ambientes (i.e. regras de difusão). A relação de vizinhança entre um nó e outro pode ser obtida pela representação espacial provida pelos sistemas de localização. A mais direta seria através das próprias tabelas de endereçamento de rede que mantém atualizadas as informações sobre vizinhos para a troca de mensagens. A intensidade dessa relação pode ser expressa pela proximidade geográfica dos nós, deduzida da potência do sinal recebido, no caso das redes de sensores sem fio. No entanto, a relação física é apenas um exemplo, podemos criar diferentes tipos de relações entre os objetos baseados na aplicação e no contexto vigente naquele momento. 
Bandini, Manzoni e Simone (2002) sugerem três tipos de interações entre agentes situados em nós vizinhos: reação, emissão e disparo. A reação permite que dois agentes alterem seus estados sincronizadamente após estabelecerem um acordo entre si. A emissão é uma forma de um agente enviar e receber informações dos vizinhos. O alcance de cada mensagem pode ser amplificado ou atenuado ao longo da rede de acordo com as regras de difusão. O disparo é a mudança do estado do nó sob a percepção de um específico evento no contexto local. Algumas funções especificam como essas interações podem ser comparadas e compostas para se obter novas informações sobre o meio. Segundo os autores, diferentes tipos de agentes podem ou não ser capazes de reconhecer essas informações e, em caso positivo, podem ter diferentes reações de acordo com suas especificações de comportamento.

A troca dessas mensagens na rede de sensores permite que cada nó possa colaborar com o meio, disponibilizando suas capacidades especializadas, tornando-o reativo e pró-ativo em relação aos outros para que não fique totalmente dependente das ordens dos sistemas de controle. A intenção é garantir um grau maior de autonomia e para que seus recursos computacionais não sirvam apenas para a conversão e transmissão de sinais dos sensores e atuadores. Segundo Locatelli e Vizzari (2007), métodos de colaboração têm evoluído nos últimos anos, mas a literatura ainda enfatiza a coordenação individual de cada objeto residencial (incluindo dispositivos eletrônicos e computacionais nesse termo).

\subsection{Considerações Finais}

A arquitetura de sistemas eletrônicos e computacionais proposta para o ambiente residencial foi baseada em um conjunto de requerimentos e de abstrações coerentes com o contexto socioeconômico vigente e factível diante das atuais disponibilidades tecnológicas. A opção pelo modelo descentralizado de nós de sensoriamento e controle segue os modernos conceitos da Computação Ubíqua que propõem que as pessoas irão viver rodeadas de dispositivos eletrônicos e interagir constantemente com o mundo virtual por meio de múltiplas interfaces. O crescimento da capacidade computacional dos nós é um fator que auxilia esse processo, tornando-os aptos a gerenciar uma grande quantidade de informação proveniente de outros inúmeros dispositivos eletroeletrônicos.

A análise de informações de contexto e a geração de conhecimento são importantes uma vez que o sistema deve ser capaz de gerenciar as informações provenientes dos sensores, das interfaces humano-máquinas e alterar o comportamento da residência de um modo que não cause distúrbios aos moradores, mas que ainda cumpra os requisitos de segurança, conforto e bom uso de recursos. 


\section{Geração e Análise de Informações de Contexto}

\subsection{Introdução}

Uma residência inteligente deve ser capaz de dar suporte às atividades dos moradores, interagindo com eles em todos os momentos, trazendo-lhes conforto e segurança. A casa pode se tornar sensível e responder às necessidades de seus moradores detectando, inicialmente, as condições do ambiente por meio de sensores. O evento causado pelo pressionamento de um botão ou pela variação de um sensor dispara uma rotina computacional pré-programada que pode resultar em um comando para alterar o estado dos atuadores.

A análise independente de eventos e puramente causal tem restringido a capacidade de adaptação desse modelo frente ao enorme número de variantes que o dia-a-dia de uma casa apresenta. No caso de sistemas de controle de iluminação, por exemplo, a análise exclusiva do estado dos sensores de presença não é suficiente para se obter um resultado satisfatório. À noite, se alguém se vira na cama, as luzes não devem acender. Por outro lado, se alguém se senta em uma cadeira para ler, as luzes não devem se apagar depois do período que o sensor se mantém ativo.

Para evitar essas inconveniências, os sistemas de controle domésticos devem ser capazes de ir além do disparo de ações baseados em eventos e entender como as pessoas lidam com o tempo e espaço em suas vidas. Saber quem está fazendo o que, onde e quando são informações importantes para o desenvolvimento de sistemas residenciais inteligentes.

É natural esperar que isso adicione inúmeras complicações, tanto para extrair as informações do ambiente, como para analisá-las. Desde que a Computação Ubíqua se tornou uma realidade no começo da década de 1990 muitos desenvolvedores vêm criando formas de abstrair fatores externos e considerá-los em suas aplicações. Dey, Salber e Abowd (2001) acreditam que, incorporando noções de contexto em tecnologias interativas, essas tecnologias podem se tornar mais sensíveis às sutilezas humanas. O que de certa forma corrobora com Mark (1993) e Frank (1993) que acreditam que, quanto mais próximo o sistema computacional se aproxima do jeito que as pessoas pensam, mais fácil ele será de usar.

Em um dos exemplos citados acima, se o sistema de controle de iluminação puder utilizar um conjunto maior de informações como, por exemplo, a identidade do usuário, sua localização 
(sala de estar), seu estado (sem movimentação) e a data (quarta feira, 21 horas), ele poderia inferir com maior precisão que o usuário está lendo e que a lâmpada não deve ser apagada enquanto essa ação estiver em andamento. Não foi por acaso que foram escolhidas essas quatro categorias de informações - identidade (do usuário ou dispositivo), local, data e estado. Elas são bem consagradas na literatura e fornecem um conjunto razoável de informações sobre uma determinada entidade para a dedução de contextos mais complexos. Choi, Shin e Shin (2005), por exemplo, utilizam informações do ambiente (temperatura e data) e informações do usuário (localização, expressão facial, temperatura corpórea e pulsação) para predizer suas preferências quanto ao estado de equipamentos residenciais.

\subsection{Contexto}

A noção de contexto pode destacar interpretações de alto nível de uma sucessão de eventos, que, de certa forma, é o que o cérebro humano está acostumado a fazer. E é natural esperar essa forma de codificação porque simplesmente reflete o modo humano como os desenvolvedores mapeiam objetos e fenômenos do mundo real no mundo computacional. Na década de 1960, a programação orientada ao objeto introduziu, por meio da linguagem Simula, o conceito de objetos e classes de objetos que definem em seus próprios dados e comportamentos uma representação computacional direta do mundo real (HOLMEVIK, 1994).

A definição de contexto contempla dois aspectos importantes: o primeiro é informação em si e a segunda é como ela se relaciona com as demais para gerarem novas informações de contexto. O primeiro aspecto é evidenciado na definição a seguir:

Qualquer informação que pode ser usada para caracterizar a situação de entidades (i.e. pessoa, lugar ou objeto) que são consideradas relevantes na interação entre o usuário e a aplicação, incluindo o próprio usuário e a aplicação. Contexto é tipicamente o local, identidade e estado das pessoas, grupos e objetos físicos e computacionais. (DEY; SALBER; ABOWD, 2001)

O segundo aspecto pode ser observado em Dourish (2004):

\footnotetext{
Mais do que considerar contexto uma informação, ele é uma propriedade relacional que objetos e atividades mantêm. Não é só simplesmente dizer que algo é ou não contexto; ele pode ou não ser contextualmente relevante para alguma particular atividade. O escopo do contexto é definido dinamicamente. Ele é particular para cada ocasião; produzido e mantido e ao longo do curso de uma atividade.
}

Diante dessas duas definições, o desafio é analisar os eventos que ocorrem em uma residência, gerar informações de contexto (computacionalmente codificadas) e tratá-las de modo 
que possam ser usadas para alterar o comportamento de um sistema, equipamento ou aplicação. A aquisição desses dados para a posterior análise requer uma infraestrutura de comunicação, pois é natural esperar em uma residência que as aplicações utilizem informações para compor o contexto, extraídas de diversos lugares.

\subsection{Dificuldades na Geração de Contexto}

A primeira dificuldade está em se obter informações detalhadas da situação corrente. Particularmente, no dia-a-dia de uma residência, os moradores não deixarão explícitas suas necessidades, nem suas vontades. O sistema então terá que deduzi-las baseando-se em associações entre as várias entidades envolvidas naquele momento e sujeito às incertezas inerentes a todo o processo.

O segundo problema a se enfrentar quando se lida com contexto são os formatos de dados e protocolos usados na infraestrutura. Os dados provenientes de um sensor contêm vários atributos, como precisão, granularidade, etc., que afetam como ele é interpretado como um contexto de ordem superior (HONG; LANDAY, 2001). É importante ressaltar que a qualidade da informação de contexto, QoC (do inglês, Quality of Context) é diretamente dependente da qualidade dessas informações. A fim de se obter um sistema interoperável, a formatação deve ser simples o suficiente para ser implementada em praticamente qualquer dispositivo e usada em qualquer aplicação. Mas, ainda ela deve ser capaz de representar os detalhes e nuances que caracterizam as informações de contexto).

\subsection{Categorias de Contexto}

Os modelos introduzidos por Dey, Salber e Abowd (2001) e Zhang et al. (2006) descrevem mecanismos de múltiplos estágios de formação de contexto que se utilizam da análise de dados provenientes de sensores para gerar informações de mais alto nível. Segundo Zimmer (2004), a forma mais básica, denominada por ele de contexto de primeira ordem, é composta pela informação de um transdutor mais uma meta-informação que pode ser usada para interpretar esse dado proveniente da leitura do sensor. Por exemplo, a descrição do tipo do transdutor permite transformar a tensão em seus terminais em temperatura. A meta-informação é provida pelo sistema e não pode ser medida de nenhuma forma. Qualquer outra informação de contexto baseada em pelo menos uma de primeira ordem é chamada de contexto de ordem superior (Figura 8).

Zhang et al. (2006) descrevem uma outra forma interessante de qualificar a informação de 
contexto. Sem distingui-las hierarquicamente, eles propõem três grandes grupos baseados no caráter qualitativo e que é útil para definir as responsabilidades dos agentes gerenciadores de contexto na fase de desenvolvimento da arquitetura de sistemas residenciais: (i) Contexto de ambiente: local, data, temperatura, etc.; (ii) de equipamentos: estado de dispositivos; (iii) do usuário: necessidades do usuário, interesses, personalidade, etc.

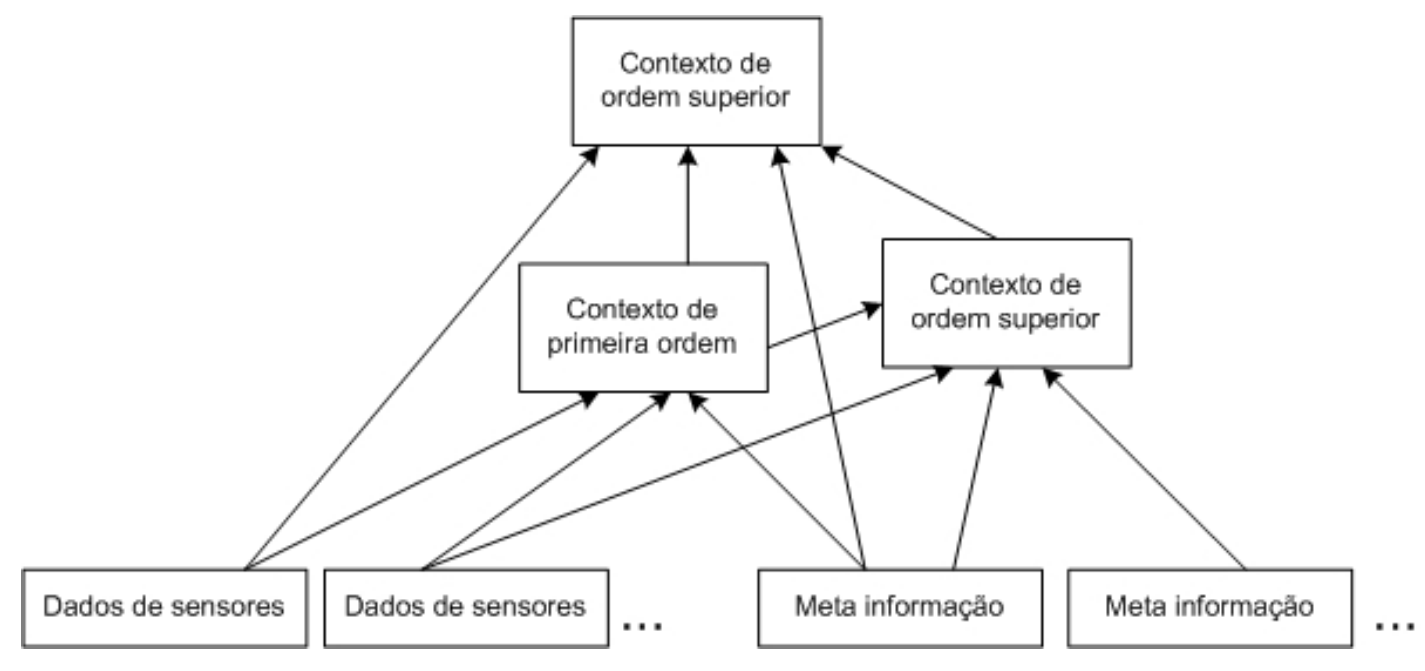

Figura 8: Categorias de contexto (Zimmer (2004))

O uso de múltiplos estágios de formação de contexto é apenas um indício da elevada dificuldade em se analisar dados de baixo nível provenientes de sensores e gerar informações de alto nível, próximo à linguagem humana, em um único estágio. Essa abordagem tenta simplificar a construção de programas computacionais, dividindo o problema e distribuindo responsabilidades. Essa divisão é desejável porque as informações de contexto, sua linguagem e o tratamento dado a elas diferem de um nível ao outro. Um estágio único, além de ter uma complexidade elevada, não se beneficiaria dos recursos que a própria natureza distribuída das informações de contexto pode fornecer. Qualquer dispositivo pode disponibilizar essas informações e tem sido uma boa prática adicionar meta-informações já na origem, próximas aos transdutores.

Com o crescente aumento das capacidades de processamento e memória no nó de controle é possível deduzir informações de contexto no próprio nó antes de enviar as informações ao sistema. Um exemplo interessante que utiliza esse conceito é a Aware Pen (BERCHTOLD et al., 2008) que disponibiliza informação de contexto de primeira ordem no próprio nó de controle. A Aware Pen é uma caneta-pincel para quadro branco que, por meio de um acelerômetro e de uma lógica computacional embutida em um microprocessador - ambos presos ao próprio corpo da caneta -, reconhece os movimentos do usuário e os classifica em situações como "escrevendo", "brincando" ou "descanso". Essas informações são enviadas a um sistema que ativa uma câmera que fotografa o quadro branco logo que a caneta deixa de ser usada. 


\subsection{Contexto de Primeira Ordem}

Dey, Salber e Abowd (2001) introduzem quatro categorias essenciais de contexto: identidade, estado, local e data, que, em outras palavras, fornecem informações sobre "quem" ou "o que", "como", "onde" e "quando". Apesar desse conjunto não ser exaustivo, segundo os autores, ele provê informações suficientes para se deduzir uma grande variedade de contextos mais complexos.

A identidade se refere à capacidade do sistema em prover um identificador único para uma entidade no espaço de nomes de uma determinada aplicação. A entidade pode ser usuários ou coisas. Objetos podem ser identificados por portarem algum tipo de elemento identificador como, por exemplo, o próprio código de barras impresso na embalagem, etiquetas de identificação por radiofreqüência (KOCH et al., 2007), ou pela análise de imagens (NELSON; GREEN, 2002) ou pela variação de temperatura proposta por (POTOCNIK; DIVJAK, 2004).

A identificação dos moradores pode ser validada por meio de um dispositivo biométrico que leia a impressão digital ou a íris do olho. O usuário pode ser identificado também por portar um cartão magnético, smart card ou uma etiqueta de identificação por radiofreqüência. Os cartões e etiquetas são úteis para saber se o usuário está ou não em casa, mas é pouco provável que seja usado para indicar a locomoção de um cômodo a outro. Alguns sistemas de rastreamento disponibilizam informações de identidade e posição simultaneamente como no caso de câmeras estereoscópicas (KHAN et al., 2001), sensores de pressão no piso (ORR; ABOWD, 2000), laser e câmeras (CUI et al., 2005), ultra-som (NISHIDA et al., 1927) ou sistemas de posicionamento por triangulação de radiofreqüência (JOY; LAXMAN, 2007). Os maiores entraves para o uso de câmeras ainda são a dificuldade na análise das imagens, a carga computacional envolvida e questões de privacidade.

O estado identifica as características intrínsecas da entidade em questão. Se for um espaço, pode ser a temperatura ambiente, a luminosidade, etc. Se for uma pessoa, ele pode se referir às suas funções vitais, por exemplo.

O local é a informação de posição bidimensional, mas pode ser expandida para incluir elevação e orientação. É utilizada para deduzir relações espaciais entre entidades como proximidade ou se uma está contida na outra. Shafer, Brumitt e Cadiz (2001) consideram o local uma das mais importantes informações de contexto porque permite que o sistema saiba que dispositivos estão livres para interagir e com quem ela irá acontecer. O local também se aplica a espaços. Em uma residência é essencial saber identificar quais os espaços que a compõem e como estão dispostos geograficamente (quais são vizinhos, etc.). As informações de localização 
são providas pelos sistemas de rastreamento mencionados acima.

Um importante aspecto em residências inteligentes é a habilidade em inferir sobre o tempo. Certas coisas devem ser feitas em certos horários. O uso dessas informações é útil para que o sistema possa criar relações temporais entre eventos e deduzir sobre o que o usuário está fazendo em um determinado momento, predizer suas próximas ações e oferecer um suporte mais adequado àquela situação. A informação de tempo pode ser fornecida por um relógio interno do sistema ou por outra fonte confiável.

Outros autores, apesar da distinção na nomenclatura também propõem a geração de contexto em camadas. Para Yang, Jansen e Helal (2006), existem simples estados como frio, quente, úmido, que podem ser diretamente medidos pelos sensores, conhecidos como contextos atômicos. Contextos mais complexos podem ser definidos como combinações de contextos atômicos. Segundo eles, em um dado momento podemos tirar uma foto de um estado observado e ordenálos de acordo com a preferência. Por exemplo, quente e úmido seria preferível ao frio e seco. Se o eventual contexto ativo não fosse o desejável, gostaríamos que, ativando os atuadores, atingíssemos o contexto apropriado.

Contextos extremamente indesejados como: quente e com fumaça, indicando que a casa está pegando fogo, são chamados de contextos não permitidos. Se em algum momento ele se torna ativo, ações de emergência devem ser tomadas para resolver a situação o mais breve possível.

Seguindo esse modelo, o processo de desenvolvimento de sistemas residenciais inteligentes se inicia com a descrição dos contextos de interesse para a casa inteligente. Em seguida, devese definir um mapeamento entre a leitura dos sensores e os contextos atômicos. O inverso também é necessário, definindo-se os estados de um conjunto de atuadores que estabelecem cada contexto atômico.

Os efeitos dos atuadores devem ser definidos em termos de como eles afetam os sensores disponíveis. Dessa forma podemos prever como eles afetarão o contexto ativo. Finalmente, para os indesejados, definimos quais atuadores devem ser ativados ou desativados.

\subsubsection{Geração de Eventos Discretos}

A geração de informação de contexto de primeira ordem se dá diretamente da análise de eventos provenientes de sensores. Uma infraestrutura física de rede é responsável por transportar os dados dos sensores até um ambiente computacional que possa identificá-los, gerando eventos do tipo: 
$<$ obj $><$ estado $><$ data $>\rightarrow<$ temp_sala $><23^{\circ} \mathrm{C}><2009 a 12 m 30 d 15 h 40 m 32 s>$

O conjunto de informações acima descreve o estado de cada transdutor instalado nos cômodos da residência sem que haja ambigüidades. Geralmente, cada nó de controle recebe um número único, identificando-o inequivocamente naquele domínio da aplicação. O mesmo acontece com cada transdutor em um nó específico. Cada sensor ou atuador recebe um código único que define sua função e seu conjunto de propriedades. Dessa forma, associando-se esses identificadores, a informação do estado dos transdutores provenientes de qualquer nó é também livre de ambigüidades:

$$
<i d \_d o \_n o ́><i d \_d o \_t r a n s d u t o r ~><e s t a d o \_d o \_t r a n s d u t o r>
$$

Basta associar cada nó de controle com um local específico da casa e é possível descrever o estado desse local analisando o conjunto de informações provenientes dele. Por outro lado, também é possível modificar o estado físico desse local, enviando comandos ao atuador do nó em questão. Uma simples tabela geralmente é suficiente para associar cada nó com seu respectivo local e lista de transdutores. Um exemplo pode ser visualizado na Tabela 3.

\begin{tabular}{cccccc}
\hline Nó & Local & Id transdutor & Tipo & Grandeza & Estado \\
\hline \hline & & AA & Sensor & Temperatura ambiente & $23^{\circ} \mathrm{C}$ \\
& AB & Sensor & Umidade relativa do ar & $76 \%$ \\
& AC & Atuador & Potência da lâmpada & $55 \%$ \\
\hline
\end{tabular}

Tabela 3: Associação do nó com o local e com sua lista de transdutores

Os dados de controle devem alcançar um sistema computacional capaz de processar as informações relativas ao objeto, demarcá-las com uma etiqueta de tempo e armazená-las para posterior análise. Assim, podem-se gerar os seguintes eventos:

$<$ obj $><$ estado $><$ data $>\rightarrow<$ temp_sala $><23^{\circ} C><09 a 12 m 30 d 15 h 40 m 32 s>$ $<$ obj $><$ estado $><$ data $>\rightarrow<$ umid_sala $><76 \%><09$ a12m30d15h55m52s $>$ $<$ obj $><$ estado $><$ data $>\rightarrow<$ lamp_sala $><55 \%><09$ a12m30d16h46m35s $>$

A tabela sobre os objetos é importante porque relaciona algarismos de identificação dos nós e transdutores a objetos tangíveis. Os eventos gerados trazendo dados sobre local, data e estado serão a fonte de informação para os geradores de contexto de primeira ordem e para os sistemas de controle da residência inteligente. 
Podemos destacar três grupos principais de eventos:

- Eventos de usuários: todos os eventos produzidos pelos usuários no cotidiano da residência inteligente. Geralmente, eles são iniciados por meio de interfaces como botões, potenciômetros e telas de toque, ou mesmo por meio da própria movimentação, criando mudanças de posição no sistema de rastreamento.

- Eventos do ambiente: todos os eventos gerados por fontes externas como os provocados pela natureza como iluminação externa, temperatura ambiente, umidade relativa do ar, etc.

- Eventos do sistema: todos os eventos produzidos pelos próprios sistemas de controle como o acionamento de atuadores.

Essa subdivisão facilita a análise dos eventos para a geração de informações de contexto proposta por Zhang et al. (2006), já mencionada anteriormente: (i) de ambiente; (ii) de equipamentos; (iii) do usuário.

\subsubsection{Análise Temporal de Eventos Discretos}

Em um sistema residencial baseado em eventos, toda vez que o ambiente monitorado sofre uma mudança, os sistemas de controle são informados. Um evento pode disparar uma série de outros eventos ou atividades. O sistema é dito discreto porque a continuidade do tempo no mundo real é quebrada em períodos pré-definidos de tempo. Esse processo começa desde a digitalização dos sinais analógicos dos sensores pelos conversores analógico-digitais até o compartilhamento dos ciclos de máquinas dos processadores que analisam as informações das residências inteligentes. Essa técnica amplamente adotada atualmente reduz consideravelmente a quantidade de informação gerada e facilita o armazenamento e posterior tratamento dessas informações.

A relevância do evento está em sinalizar aos sistemas de controle que o ambiente monitorado sofreu uma mudança. Ele é considerado um feito instantâneo para facilitar sua análise. $\mathrm{O}$ quanto as características do ambiente devem se alterar para dispará-lo é ajustado pela aplicação e pode ser diferente para cada sensor. Fica a cargo da aplicação, por meio do gerenciador de eventos, identificar o evento ocorrido, armazená-lo para futuras análises e disparar as ocorrências.

Ao contrário dos eventos, as atividades têm uma duração de tempo e, cada uma é associada a um ou a um conjunto de eventos que a inicia. Alguns eventos também podem ser disparados 
quando uma atividade se encerra. Em muitas ocasiões do mundo real, as atividades e o processo são conhecidos. O sistema apenas fica no aguardo, esperando a atividade que resultará na conclusão do processo.

Numa residência inteligente, mais especificamente, nas interações do usuário com a casa, não são raras as vezes que o sistema tem que observar as ações dos moradores para tentar descobrir o processo que mais se encaixa naquele momento para que ele possa entender o contexto vigente naquele momento e assim, reduzir o erro de suas manifestações.

Não se pode esperar que o morador sinalize a todo o momento qual será sua próxima ação ou vontade. É nesse momento que a residência inteligente deve possuir a capacidade de monitorar a identidade, local, data e estado para tentar identificar o contexto corrente.

Identificar a correta granularidade temporal também é importante tanto para a análise de eventos e geração de contexto quanto para as camadas de aplicação. Grânulos muito grandes podem esconder transições e informações relevantes, e grânulos muito pequenos sobrecarregam desnecessariamente o sistema. Usando corretamente esses grânulos é possível descrever um fato ou notar alguma anormalidade nas atividades por meio da qualificação temporal.

\subsection{Restrições do Domínio de Estados de um Objeto}

Vários fatores podem restringir o domínio de estados de um objeto. No nível mais baixo, a qualidade do sensor empregado é o que define os valores máximos e mínimos, bem como a precisão e o erro da grandeza a ser medida (válido para medição direta, sem nenhuma inferência estatística). Outro fator, a digitalização de sinais analógicos, tem sido uma prática comum efetuada nos nós de controle e que minimiza o efeito de ruídos na transmissão dos sinais provenientes dos sensores e facilita a posterior manipulação e armazenamento desses sinais. A precisão da amostra digital depende diretamente da qualidade do conversor empregado considerando sua resolução, linearidade, ganho, dentre vários outros aspectos. A resolução indica o número de códigos que o conversor pode produzir frente ao sinal analógico. Resoluções muito acima das necessidades do projeto, além de encarecê-lo, tornam o conversor sujeito a ruídos, sobrecarregando o sistema de controle com medições desnecessárias. Por outro lado, conversores com baixos índices de resolução podem ocultar variações legítimas do transdutor.

Sensores de umidade relativa do ar, por exemplo, de uso comercial e de baixo custo ( US\$ 8,00), como os da linha HTH-5031, da Honeywell, apresentam as seguintes especificações (HONEYWELL, 2009):

- Faixa de operação $\left(20^{\circ} \mathrm{C}\right): 0 \%$ a $100 \%$ UR 
- Erro (11\% a $89 \%$ UR): $+/-3 \%,(0 \%$ a $10 \%$ e $90 \%$ a $100 \%):+/-7 \%$ para $\mathrm{Tamb}=25^{\circ} \mathrm{C}$

- Estabilidade: $+/-1.2 \%$ a cada 5 anos

- Relação tensão x umidade: Vout $=0.5+(0.021$.UR $)$

Conversores analógico-digitais comerciais de baixo custo têm resoluções em torno de 12 bits com erro de linearidade integral de $+/-2$ bits. Isso equivale à quantização de um sinal de 3.3V em 4096 códigos diferentes: (3.3 - 0) / 4096 = 0.8 mV/código, com 0.05\% (2/4096) de erro. Como o sensor de umidade, descrito acima, apresenta um erro mínimo de $+/-3 \%$ na região de $11 \%$ a $89 \%, 14$ códigos resultantes do conversor analógico-digital representam o mesmo valor medido, e por conseqüência, transmitidos sem necessidade.

A aplicação também pode restringir o domínio de estados, mas ao contrário das inconvenientes restrições impostas pelo próprio sensor e pelo processo de digitalização, existem importantes vantagens que motivam essa técnica. A primeira é restringir o domínio para não sobrecarregar o processamento computacional com excesso de informação uma vez que a sensibilidade humana às variações do ambiente acontece em um nível macroscópico e não percebe mudanças infinitesimais. Um exemplo interessante relatado por Newsham, Mancini e Marchand (2008) cita um experimento com algumas pessoas em um escritório cuja iluminação inicial de 500 lx começa a ser gradualmente diminuída. Os participantes devem indicar quando sentirem alguma alteração. Em geral, a variação só foi percebida quando o nível de iluminação foi reduzido em $20 \%$.

A segunda vantagem é facilitar a tomada de decisão e a construção de interfaces, incentivando o uso de informações de contexto e reduzindo a manipulação numérica dos dados provenientes dos sensores. Isso se deve ao fato que algumas grandezas físicas são mais familiares às pessoas do que outras. A temperatura ambiente talvez seja o exemplo bem familiar de grandeza física no cotidiano das pessoas. Em geral, elas sabem identificar os diferentes níveis e relacioná-los com seu conforto. A TV se utiliza dessa informação para compor os relatórios sobre o clima. Dessa forma, é de se esperar que uma interface disponibilize ao morador um ajuste gradual de temperatura em, no mínimo, unidades de graus Celsius ou Fahrenheit, e que o sistema de controle seja capaz de alcançar o valor desejado, pois são grandes as chances do usuário conferir o resultado da sua solicitação pelo termômetro.

A umidade relativa do ar é um caso intermediário. Apesar de estudos revelarem sua influência na sensação de conforto térmico e se utilizarem dessa informação para reduzir o consumo de energia em sistemas de ar-condicionado, como, por exemplo, no trabalho de Wan et al. (2009), ela só é lembrada em casos extremos de desconforto como muito seco $(<30 \%)$ ou muito úmido 
(> 80\%). Nesse caso, a informação dos sensores de umidade relativa deve estar disponível na íntegra para os sistemas de controle determinarem a curva ótima de trabalho, mas as interfaces podem omitir os detalhes e exibirem talvez apenas a faixa de conforto.

Já a luminosidade é um caso de grandeza pouco familiar no cotidiano de moradores de uma residência. Somos capazes de avaliar empiricamente se ela é adequada a certa atividade, mas raramente a associamos com sua grandeza, o lux (lx). O lux é uma unidade do sistema internacional que mede a quantidade de fluxo luminoso (em lumens) por metro quadrado. Em outras palavras, ele diz o quanto de luz é necessário para iluminar a área desejada. Por exemplo, uma lâmpada incandescente comum de $100 \mathrm{~W}$ emite cerca de 1500 lumens (PHILIPS, 2008) e, se acondicionada em um refletor apropriado, pode fornecer os 500 lx, valor indicado para os trabalhos realizados em uma cozinha. Mas não é trivial associar conforto visual com a luminosidade, pois o olho humano produz sensações diferentes para cada cor. Por esses e outros fatores é que as interfaces residenciais de iluminação não são graduadas em lux. Os equipamentos comerciais apelam a outras sensações para descrever a intensidade de um conjunto de lâmpadas, criando cenas com o título de "festa" ou "leitura".

Os sistemas de controle residenciais podem tirar proveito desses fatos e reduzirem o domínio de estados de centenas de níveis possíveis de iluminação - para uma só lâmpada - para menos que uma dezena. Uma técnica bastante utilizada é usar os conceitos de lógica difusa ( fuzzy) para agregar os níveis de entrada em classes com características semelhantes. Para cada classe, então, é criada uma função de pertinência, que indica o grau de pertinência de seus elementos. Normalmente, essa função é criada de forma a representar algum conceito impreciso, como, no caso de uma residência, por exemplo, "frio" ou "úmido".

Outra técnica, aliada à restrição do domínio de estados, para reduzir a carga computacional é analisar a velocidade com que as grandezas físicas variam no ambiente residencial. Se ela costuma variar lentamente no tempo então não há a necessidade de se gerar eventos, poupando os sistemas de controle. Os protocolos de transmissão de dados em redes de sensores são incisivos nesse aspecto devido à preocupação em minimizar o gasto de energia nos nós de controle energizados à bateria. Menor a quantidade de transmissão de dados, menor o tempo que o dispositivo fica ativo, mais duradoura é a carga da bateria.

O protocolo ZigBee descreve, por exemplo, dois mecanismos independentes que controlam o envio de dados de sensores. O primeiro estabelece um período que o nó deve reportar esse dado. O segundo estabelece uma variação mínima do sensor que dispara o envio da informação ao sistema de controle (ZIGBEE, 2007a). A aplicação também pode determinar o tempo de requisição entre as consecutivas medições dependendo da ocasião. Por exemplo, no controle de 
conforto térmico, a aplicação pode requisitar mais amostras de umidade relativa em cômodos ocupados, para melhorar o gerenciamento, e diminuir o número de amostras em ambientes sem ocupação.

\subsection{Contexto de Ordem Superior}

Gottfried, Guesgen e Hubner (2006) recomendam que a abordagem usada na geração de contexto de ordem superior seja semelhante a como os humanos relacionam espaço e tempo em seu dia a dia. Eles alegam que, raramente, medições precisas como, por exemplo, as usadas na Física, são necessárias para resolver os problemas dentro de uma residência.

Outro aspecto é representação das entidades. No caso do tempo, os computadores controlam suas tarefas baseados em um relógio assim como as pessoas fazem. Mas as residências inteligentes também devem desenvolver a percepção de granularidade temporal do mesmo modo que dia, mês, minutos, etc. fazem sentido para as pessoas. A análise de duração de tarefas também é uma habilidade humana importante a ser desenvolvida. Se uma tarefa não transcorre em um tempo que consideramos como normal, a residência deve ser capaz de sinalizar o problema.

No caso do espaço, segundo Freundschuh e Egenhofer (1997), o uso de coordenadas cartesianas para definir geograficamente um espaço pode ser útil para a análise computacional, mas não necessariamente reflete o modo como as pessoas experimentam os espaços físicos no seu dia-a-dia. O conceito de pontos, linhas e polígonos que definem objetos vetoriais na computação não necessariamente têm relação direta com os objetos do mundo real. As pessoas não notam a precisão como o ambiente é construído, mas a percepção humana nota formas (quadrado, redondo, etc.), padrões e posições relativas (está na frente, está atrás).

Baseado no conceito de image schemata proposto por Johnson (1987), essas informações, associadas com o perfil emocional, cultural e cognitivo do usuário, resultam em estruturas que têm significado e que permitem racionalizar frente ao ambiente. Se a residência inteligente entende como essas estruturas são feitas, ela pode ser capaz de inferir melhor em suas tomadas de decisões.

Diversas discussões sobre a caracterização de espaços podem ser encontradas no trabalho de Freundschuh e Egenhofer (1997). Alguns autores caracterizam o espaço pelo seu tamanho relativo ao tamanho do homem. Elas se baseiam, explicitamente ou não, em quatro fatores: (i) no tamanho do espaço; (ii) se é manipulável ou não; (iii) se sua visualização depende de locomoção; (iv) e o tempo empregado para a sua visualização.

Em resumo, em espaços de pequena escala, como uma sala, a pessoa pode ver os lugares 
e objetos de um único ponto de vista, empregando um curto período de tempo. Os objetos têm dimensões parecidas ou menores do que as do corpo humano. Em contraste, espaços de grande escala, como uma casa, por exemplo, necessitam de locomoção e de um período de tempo longo para que se visualizem todos os seus espaços. Eles necessitam de representações simbólicas, como mapas, para representá-los em dimensões de pequena escala. Essa representação é importante porque, segundo Frank (1996), a reação cognitiva das pessoas varia de acordo com a escala. Kolars e Nystuen (1975) também consideram sua influência na interação e nas interpretações do ambiente.

\subsubsection{Detecção de Pessoas}

O desenvolvimento de sistemas de controle residenciais requer uma análise conjunta de vários fatores para balancear as necessidades dos usuários (conforto, usabilidade, etc.) com a disponibilidade dos recursos.

Cada morador tem suas preferências e é natural esperar que ele deseje que a casa se adapte ao seu estilo de vida. A padronização das ações, o uso do senso comum, seria insuficiente para lidar com todos os detalhes e variações do comportamento humano. Shafer et al. (2000) sugerem que o ambiente precisa manter um modelo computacional de cada morador. As informações sobre o local e a identidade de cada usuário, disponíveis pelos geradores de contexto de primeira ordem, devem ser utilizadas para determinar suas preferências pessoais por meio do registro histórico de suas ações.

\subsubsection{Detecção de Tarefas}

A interação entre a residência inteligente e os moradores deve ser balanceada de forma que a casa não requisite a atenção do usuário a todo o momento, e, por outro lado, não execute todas as funções sem consultá-lo primeiro. Pesquisadores do MIT Home of the Future Consortium têm investigado como a tecnologia e novos produtos e serviços poderiam melhor se ajustar às necessidades do futuro. Eles acreditam que a casa do futuro não usará a tecnologia para automatizar todas as tarefas, mas para ajudar o usuário a cumpri-las de acordo com a sua vontade, sem pensar por ele (INTILLE, 2002). As informações devem estar precisamente dispostas no tempo e no lugar, auxiliando na tomada de decisões. O sistema, por meio de aprendizado e adaptação, deve fornecer sugestões para o gerenciamento de todo o ambiente residencial. Segundo Rodin e Langer (1977), a retirada do controle por parte do usuário mostra uma sensação de impotência psicológica e física. 
A alocação de funções, isto é, se uma determinada tarefa deve ser realizada por humanos ou por agentes artificiais, deve considerar primeiramente o tipo da tarefa: se é repetitiva; se é arriscada; se compensa criar um processo de automatização para ela; e quem é o mais apropriado para executá-la. A lista a seguir ilustra os níveis de automação, adaptados de (SHERIDAN, 2002):

- A residência não oferece nenhuma assistência, o humano deve fazer tudo;

- A residência sugere métodos alternativos de se realizar uma tarefa;

- A residência escolhe um método para realizar uma tarefa, e

- Executa uma tarefa apenas se há a aprovação de um humano, ou

- Permite um tempo restrito para veto antes que execute uma tarefa, ou

- Executa uma tarefa automaticamente e necessariamente informa o humano, ou

- Executa uma tarefa automaticamente e informa o humano apenas se requerido;

- A residência seleciona um método, executa a tarefa, e ignora o humano.

A automação é interessante nas ocasiões em que a velocidade de processamento dos computadores em executar determinadas tarefas compensa o tempo gasto em planejar e programar o computador para realizá-la. No ambiente residencial, o interesse em automatizar as tarefas surge do fato da ausência do usuário (o dia todo trabalhando), da impossibilidade (idosos e deficientes) ou mesmo se estiver em casa (trabalhando, estudando, descansando ou se divertindo), não pode perder tempo com as tarefas rotineiras.

Em sistemas mais complexos, pode surgir a necessidade de se dinamizar a alocação de funções e o homem e a máquina podem efetuar um compartilhamento (funções em paralelo) e alternância (cada um controla num período de tempo) dessas funções. O compartilhamento é interessante, por exemplo, quando o homem controla alguns graus de liberdade enquanto a máquina controla outros, fazendo melhor uso de ambos os recursos. A alternância é importante em situações em que um realiza uma tarefa e o outro realiza um processo de verificação.

A alocação adaptativa, segundo Sheridan (2002), é dinâmica e depende do contexto e da carga sobre o humano. A troca de funções pode ser requisitada por um ou por outro, a qualquer momento, caso não consigam concluir uma tarefa.

A análise de tarefas revela como cada tarefa está relacionada no tempo e espaço, e quem é o responsável por ela. Cada tarefa envolve especificar a informação relacionada, listar as 
possíveis decisões e ações a serem tomadas, definir um critério de satisfação e atribuí-lo a cada passo.

\subsubsection{Detecção de Rotinas}

As rotinas estabelecem a estrutura de como as tarefas domésticas são realizadas. Como notaram O’Brien et al. (1999):

Rotinas são baseadas em sofisticados e intangíveis sistemas de comunicação e entendimento entre os membros da família. Elas fazem com que as tarefas sejam realizadas sem ter que, a todo o momento, haver explicações, inspeções ou a necessidade de se criar novas seqüências a cada ocasião. A vida das pessoas é baseada em rotinas. Escovar os dentes, preparar o café da manhã, passar roupa, cozinhar e ver televisão é um exemplo de rotina que as pessoas executam diariamente. As rotinas podem ser as mesmas, mas o jeito de fazê-las varia de casa a casa, de pessoa a pessoa. É por isso que desenvolver sistemas e dispositivos para casas inteligentes, que são tão dedicados e pontuais, é tão desafiador. É difícil saber que critérios devem ser considerados para que possam atender os interesses da maioria.

A análise das rotinas diárias dos moradores de uma residência revela que cada habitante descreve alguma forma de padrão comportamental que pode ser medido, interpretado e aprendido. Segundo Roy et al. (2005), embora esses padrões variem com o tempo, tais mudanças não são freqüentes e nem aleatórias.

A observação das rotinas é um processo delicado porque acaba ferindo a privacidade dos moradores. Alguns autores utilizam questionários, entrevistas e relatórios temporais para minimizar esse efeito, mas outros ainda preferem métodos etnográficos para observar as famílias dentro da própria residência para detectar nuances e detalhes que não seriam percebidos com o uso de outras técnicas.

A Etnografia é a especialidade da Antropologia que estuda e descreve os povos, sua língua, raça, religião, etc. O antropólogo observa as ações de um grupo social (e.g. tribo indígena) em seu contexto natural durante um longo período de tempo. Segundo Mattos (2001), a etnografia estuda preponderantemente os padrões mais previsíveis do pensamento e comportamento humano, manifestos em sua rotina diária. Mas é capaz de detectar fatos e/ou eventos menos previsíveis ou manifestados particularmente em determinado contexto interativo entre as pessoas ou grupos.

Frohlich e Kraut (2003) relatam que, pelo menos desde a década de 1950, existem estudos que têm investigado como as pessoas organizam seu tempo em casa. As pessoas em questão tinham que anotar em diários, a cada 15 minutos, o que estavam fazendo, com quem e onde. 
Essas entradas eram classificadas usando-se 100 atividades padrão, como, por exemplo, dormindo, comendo, estudando, divertindo, etc. Esses estudos mostraram que as atividades são organizadas em padrões recorrentes ou rotinas. Dormir, trabalhar, recreação (especialmente assistir TV) e cuidados pessoais eram as atividades dominantes na vida dos norte americanos.

Recentemente, Robinson e Godbey (1999) desenvolveram um estudo baseado em três censos que ocorreram nos EUA em 1965, 1975 e 1985. Muitas similaridades foram encontradas, baseadas fortemente na disposição biológica e nas taxas de metabolismo em um ciclo diário de 24 horas, como, por exemplo, que a grande maioria das pessoas dorme à noite e está acordada durante o dia, ou pessoas que trabalham durante o dia, costumam assistir TV no horário nobre das 20 às 22 horas. Mas também, existem algumas diferenças entre as pessoas baseadas em como a família é formada ou a quais instituições estão conectadas. Casas onde vivem crianças ou adolescentes têm um ciclo diferente das habitadas apenas por adultos.

Segundo Tolmie et al. (2003), o conceito de rotina apareceu no ambiente corporativo, mais especificamente nos escritórios, no começo dos anos 1980 quando os desenvolvedores de tecnologia exploravam conceitos de automação no escritório (Office Automation, conhecido também pelo termo romeno, Birótica) como um meio de ter o trabalho realizado por meio de métodos cooperativos de solução de problemas e atividades repetitivas.

Philipose et al. (2004) demonstram um algoritmo que detecta rotinas analisando cada objeto envolvido e a probabilidade desse envolvimento. A probabilidade envolve três fontes de ambigüidades: os erros dos sensores, o erro do modelo (e.g. alguns objetos não são identificados pelo modelo), e a falta de especificidade do modelo (análise de objetos que não são necessários naquela situação). O cálculo da probabilidade é realizado por uma rede Bayesiana. Hara, Omori e Ueno (2002) seguem o mesmo princípio, mas usam uma cadeia de Markov para mapear a probabilidade da transição de estados.

O único problema desses modelos é que requerem constante ajuste das tabelas de sensores que determinam o começo e o fim de uma atividade. A Figura 9 mostra um modelo hierárquico e dinâmico que pode ser construído pelo próprio sistema à medida que as atividades vão ocorrendo na residência. No início do processo o desenvolvedor deve instrui-lo com uma lista das possíveis atividades que possam ocorrer em um local. O histórico vai determinar a probabilidade da ocorrência de cada transição.

A criação de sub-regiões de interesse, utilizando a informação do local onde a ação está ocorrendo, reduz consideravelmente o domínio de possibilidades a ser analisado. Por exemplo, se a análise da tarefa depende da informação de temperatura ambiente, em uma casa com dez sensores, sendo que cada sensor pode variar de $0^{\circ} \mathrm{C}$ a $100^{\circ} \mathrm{C}$, o número de possibilidades a 


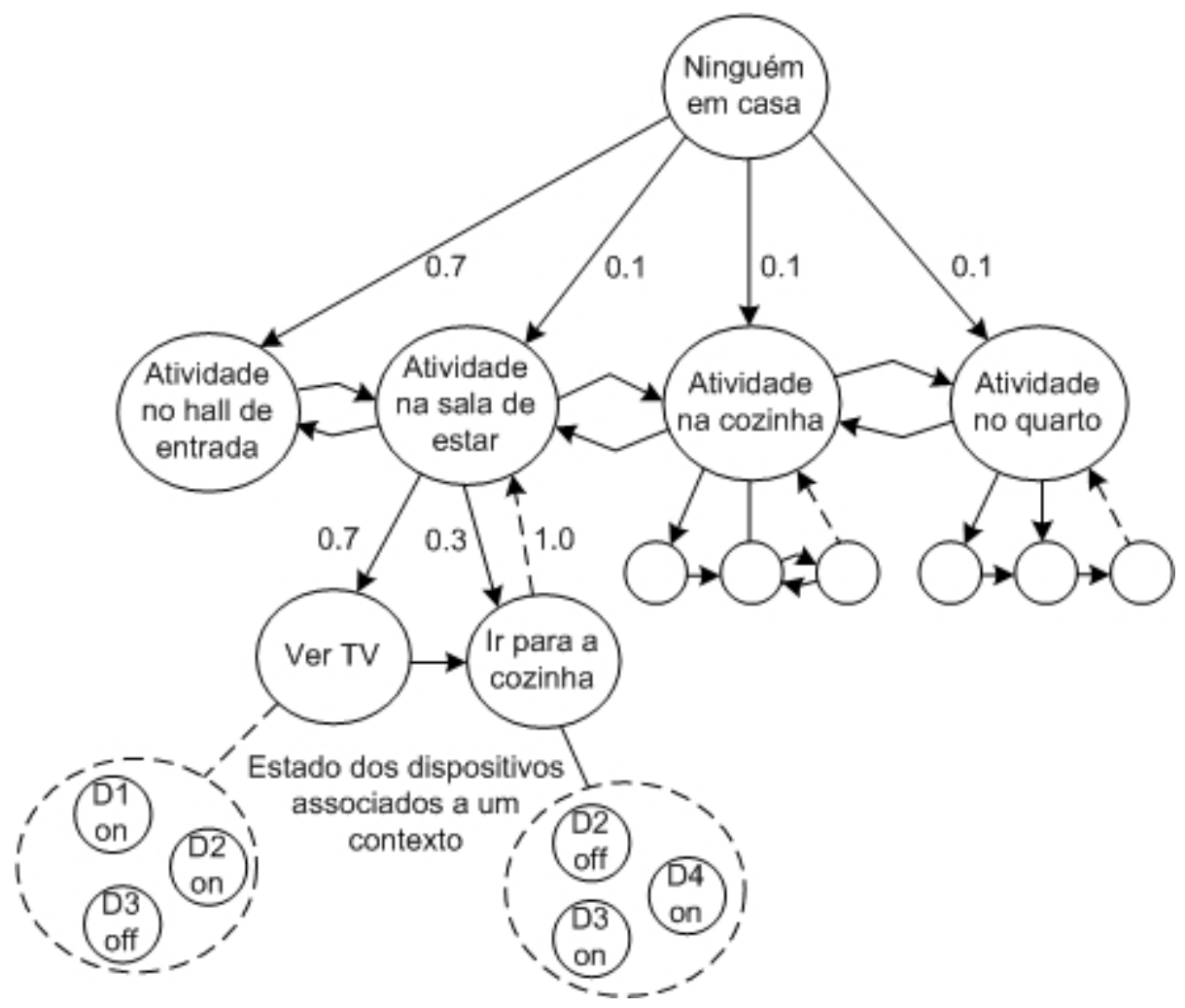

Figura 9: Modelo hierárquico para a detecção de atividades e ativação de atuadores

serem analisadas é de $100^{10}$. Introduzindo-se informações específicas sobre o local (e.g. sala de estar), o número de sensores cai para um (i.e. 100 possibilidades).

\subsection{Gerenciamento de Contexto}

A arquitetura sugerida por Dey, Salber e Abowd (2001) em seu Context Toolkit é amplamente baseada em componentes distribuídos de softwares, os Widgets, que realizam a aquisição de dados dos sensores e provêem informação de contexto para a aplicação. Eles funcionam como intermediadores entre a aplicação e o ambiente abstraindo as particularidades técnicas dos sensores. Outros módulos chamados de Interpreters transformam as informações de contexto atômico gerada pelos Widgets em informações de mais alto nível. Mas para isso, eles devem consultar os Aggregators, pois é por meio deles que as informações dos Widgets são disponibilizadas. O Context Toolkit é uma plataforma de gerenciamento de contexto desenvolvida em Java de código aberto disponível na Internet. Seu diagrama de objetos pode ser visualizado na Figura 10.

De forma análoga, Zhang et al. (2006) chamam de Agents aqueles que coletam e analisam as informações dos sensores e, de Smart Agent, o que integra e analisa todas as informações (ver Figura 11). O Context Toolkit cria uma instância de cada Widget para cada sensor e mantém 


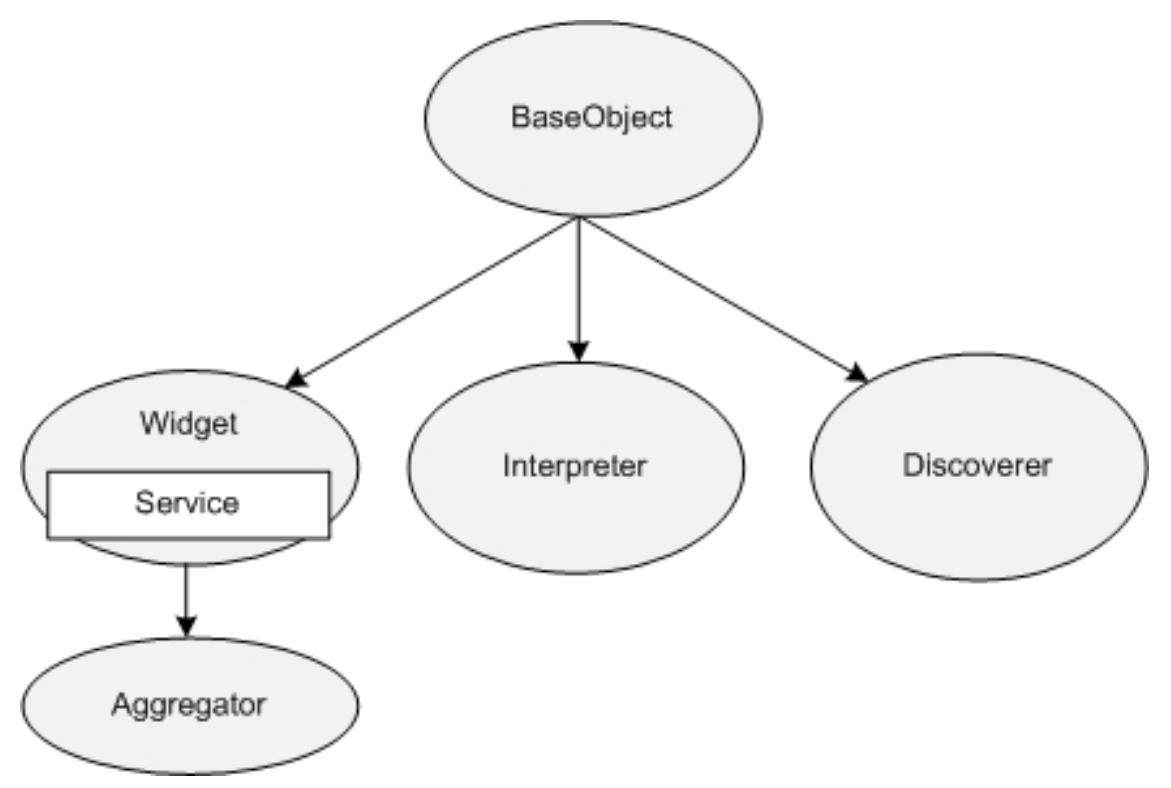

Figura 10: Hierarquia de objetos do Context Toolkit (Dey, Salber e Abowd (2001))

um registro da disponibilidade e das capacidades de todos os módulos por meio de um repositório central chamado de Discoverer. Mesmo que o repositório fique inacessível, os Widgets continuam funcionando. Por outro lado, no caso do Smart Agent, todas as informações são concentradas em um só ponto, o que pode deixar o sistema indisponível, em caso de falha.

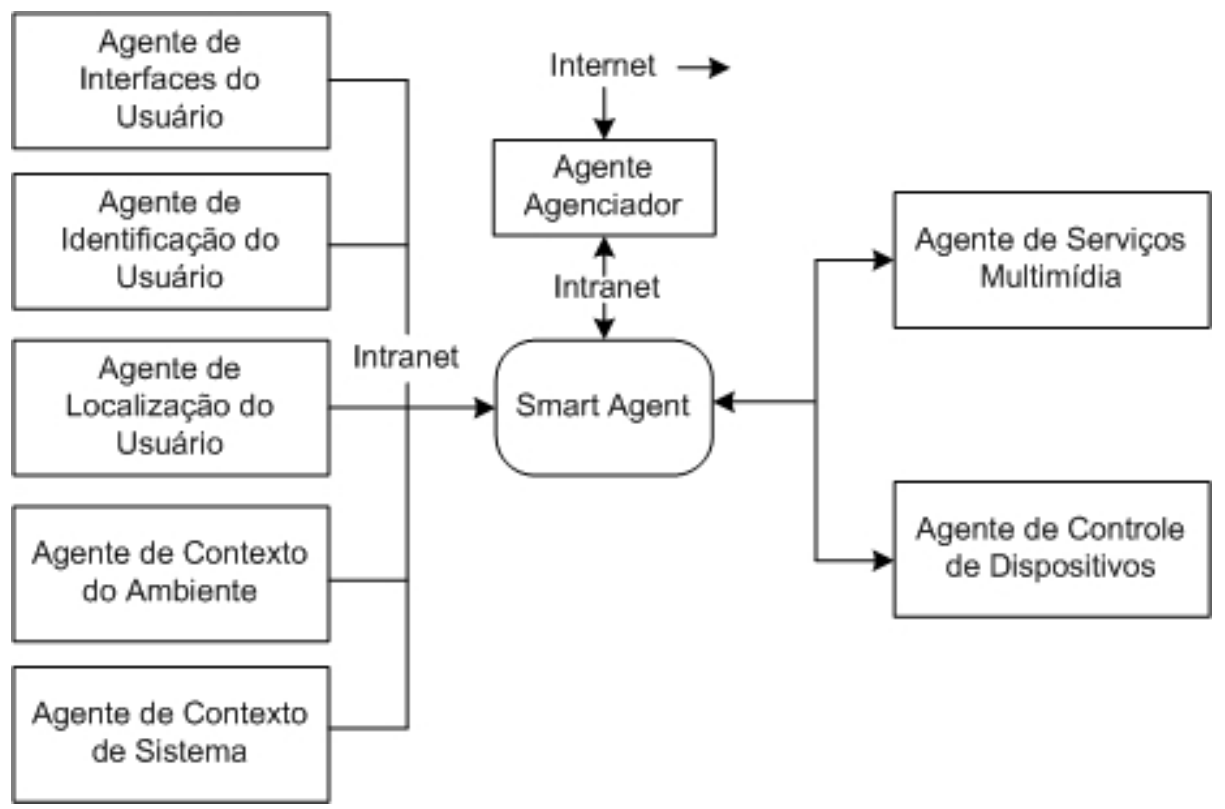

Figura 11: Modelo de gerenciador de contexto (Zhang et al. (2006))

Nunca se sabe quando uma aplicação vai necessitar das informações de contexto ou mesmo solicitar dados antigos para efetuar alguma análise de padrões, por isso os geradores de contexto devem executar seu trabalho independentemente das aplicações, fornecendo e armazenando seus dados continuamente. No entanto, assim como qualquer sistema computacional, os gera- 
dores de contexto são falíveis e dependentes de sistemas operacionais, comunicação em rede, etc. Em algumas circunstâncias a informação pode estar indisponível porque o usuário a considerou de caráter privado. Por estas razões, o gerenciador de contexto deve ser capaz de lidar com valores inconsistentes.

\subsection{Considerações Finais}

As informações de contexto têm sido utilizadas no desenvolvimento de sistemas de controle residenciais para auxiliá-los a determinarem as mais apropriadas ações, ou seja, definirem os estados dos atuadores, frente aos inúmeros dados e variáveis disponibilizados pelos sensores.

É uma prática que, de certa forma, imita como as pessoas decidem quais ações irão tomar em suas rotinas diárias. A análise concorrente de informações de baixo e alto nível é um processo transparente ao ser humano, mas que esconde um alto grau de complexidade e requer a análise simultânea de um grande número de variáveis.

Este trabalho enfatiza o uso de contexto pois essa coerência com o modo humano de resolver problemas facilita seu entendimento e o desenvolvimento de algoritmos futuros. 


\section{Descrição da Plataforma Home Sapiens}

O Home Sapiens é uma plataforma eletrônica e computacional, baseada em hardware, firmware e software. No desenvolvimento da sua arquitetura, considerou-se os aspectos tecnológicos, socioeconômicos, de saúde e ambientais, discutidos ao longo desse trabalho, com a intenção de criar um sistema viável e factível para fomentar o estudo e o desenvolvimento de residências inteligentes.

Por meio da Figura 12, que ilustra o diagrama de blocos funcionais, é importante destacar sete blocos principais:

- Rede de Sensores: formada pelos nós de controle, nó de interface, rede doméstica e conversor de mídia;

- Gerenciador de Serviços: onde todas as entidades de hardware disponibilizam seus serviços no ambiente computacional;

- Gerenciador de Conhecimento: onde acontece a mineração de dados do histórico de eventos que ocorreram na residência para a geração de informações de alto nível que irão auxiliar os sistemas de controle na tomada de decisões;

- Sistemas de Controle: onde ocorre o processo decisório que irá, efetivamente, alterar o estado dos atuadores e modificar o ambiente residencial;

- Aplicações: onde são executados os programas que identificam e reúnem as capacidades funcionais da residência provendo formas de monitoramento e automação dos processos residenciais;

- Interface com Usuário: por meio dela o usuário pode monitorar e comandar a casa remotamente;

- Gerenciador Residencial: controla as funções básicas de suporte como relógio, registros, inicialização e encerramento de tarefas, etc.

Com exceção da rede de sensores, que envolve o desenvolvimento de hardware e firmware específico, todos os outros sistemas são programas computacionais, desenvolvidos na linguagem Java e executados sobre um sistema operacional em um computador pessoal. 


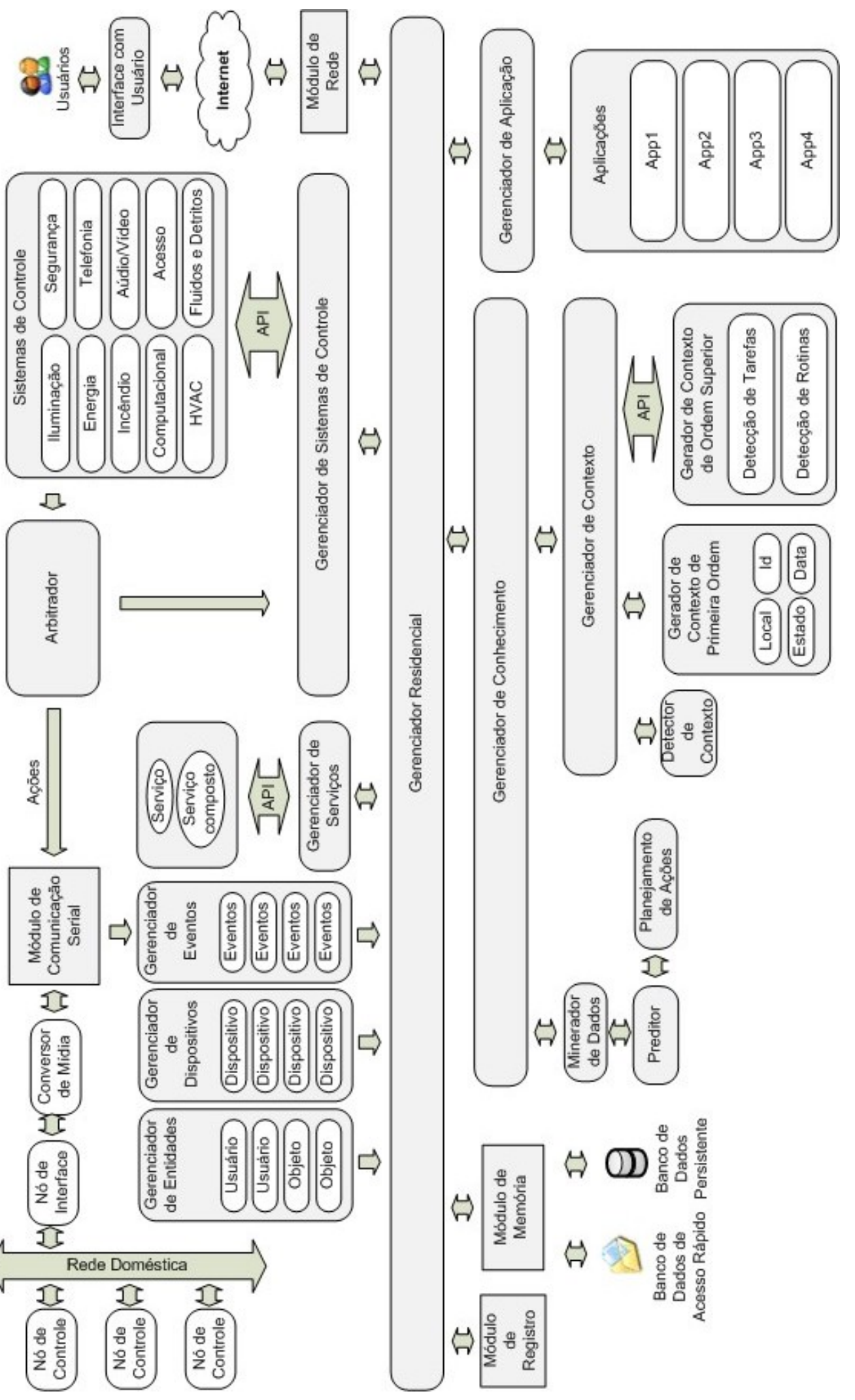

Figura 12: Diagrama de blocos do Home Sapiens 


\subsection{Nós de Controle}

\subsubsection{Hardware}

Os nós de controle que formam a rede de sensores são compostos por:

- Microprocessador que gerencia as interfaces de entrada e saída de dados, processa as informações de controle e armazena as configurações em uma memória interna não volátil;

- Sensores e atuadores;

- Sistema de comunicação sem fio que utiliza os protocolos IEEE802.15.4 (camadas física e enlace) e ZigBee (camada de rede);

- Fonte de alimentação.

A rede de sensores proposta tem qualidades importantes para o desenvolvimento de serviços de controle residenciais. Iniciando pelo fato de ser sem fio, permite que o dispositivo esteja próximo da carga controlada, o que evita a necessidade de longos cabeamentos de potência e de dados. As dimensões reduzidas do nó devido à alta integração dos componentes utilizados tornam-no compatível com a infraestrutura elétrica residencial tradicional e com os projetos de arquitetura e decoração. A Figura 13 ilustra o nó de controle e seus respectivos componentes.

Em uma primeira instância, cada nó é responsável por tratar os sinais provenientes dos sensores e encaminhar esses dados via rádio para o servidor de aplicação. Mas essa configuração torna todo o sistema dependente das ações de um gerenciador central, o que o descaracteriza no aspecto de descentralizado. A solução proposta nesse trabalho é a troca de micro agentes, mini pedaços de código, que garantem um nível apropriado de controle no próprio nó. Dessa forma, em algumas situações, o nó é capaz de tomar decisões e disparar ações alterando o estado de um atuador local ou mesmo enviar ou requisitar informações de outros nós. Caso haja uma falha no servidor de aplicação, o acesso remoto fica prejudicado, mas a natureza descentralizada de todo o sistema minimiza os danos em caso de pane, evitando que toda a casa fique sem controle, mantendo um estado seguro de funcionamento.

\section{Fonte de Alimentação}

Em aplicações de automação residencial, os nós que efetivamente controlam dispositivos de potência como lâmpadas, ar-condicionado, etc. são instalados próximos às cargas e utilizam a infraestrutura de distribuição elétrica residencial como fonte de energia. 


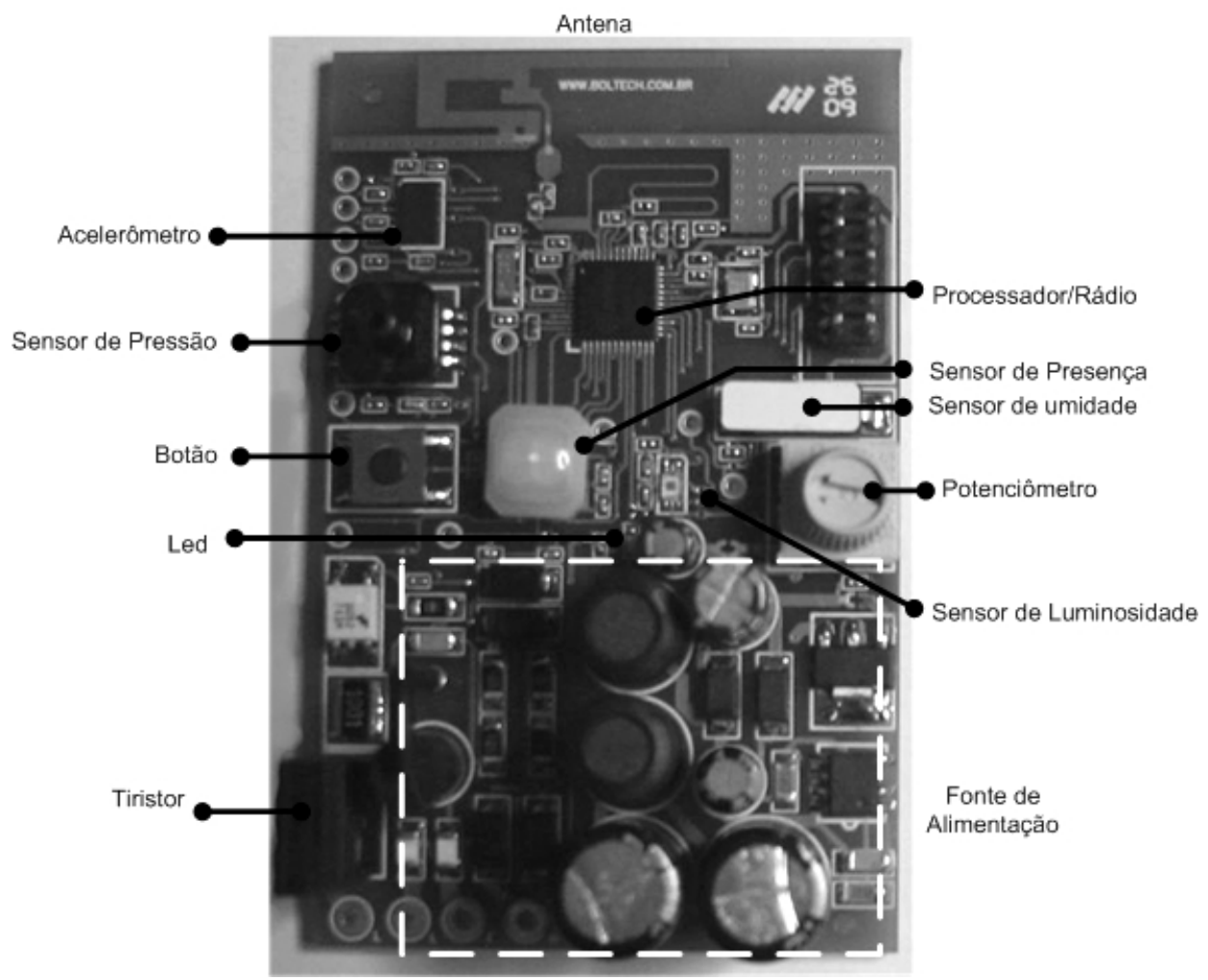

Figura 13: Nó de controle ZigBee

Sendo assim, foi necessário o desenvolvimento de uma fonte redutora de tensão, uma vez que os componentes eletrônicos usados no nó de controle operam com tensões em torno de 3 VDC e a corrente máxima total não ultrapassa 100 mA. Nessa faixa de operação, as fontes chaveadas oferecem uma relação muito boa entre custo, rendimento e tamanho. A versão usada neste trabalho é baseada na configuração Buck com realimentação direta, em que um oscilador de frequiência central de $66 \mathrm{kHz}$ controla um transistor MOS-FET chaveando a carga por um tempo de condução que varia conforme a demanda de corrente, mantendo a tensão de saída constante. Ele opera com tensões de entrada de 85 a 265 VAC e saída de 3.3 VDC, sem o uso de transformador.

Em sistemas cabeados, a falta desse componente poderia causar curto-circuito na rede elétrica, no momento da conexão entre os nós. Para sistemas sem fio, no entanto, a falta de isolamento galvânico não é um ponto crítico, compensada ainda pela redução do custo total e pelo tamanho.

\section{Microprocessador e Rádio}

O primeiro protótipo mostrado no Cap. 1 foi construído utilizando uma das primeiras versões comerciais de rádio IEEE 802.15.4, um componente da antiga empresa Chipcon (adqui- 
rida recentemente pela Texas Instruments), o modelo CC2420. Este componente trata todas as instâncias do protocolo de transmissão ponto a ponto (camadas física e de enlace), mas depende de um microprocessador externo para controlar suas funções e a interface com os periféricos (sensores, atuadores e comunicação serial RS232).

O modelo utilizado nessa segunda versão, o CC2431 (TEXAS, 2009) apresenta inúmeros benefícios se comparado com seus antecessores. O mais importante é sua alta integração que uniu o processamento, interfaces e rádio em uma só pastilha. Ele ainda disponibiliza a informação de localização de cada nó embutida no próprio hardware, por meio da comparação da potência recebida de outros nós. Essa informação é utilizada para localizar objetos e pessoas dentro da residência. A seguir, suas características básicas são listadas abaixo:

- Rádio de 2.4GHz, padrão IEEE802.15.4, CSMA/CD;

- Invólucro QLP48, 7x7mm;

- Baixa corrente de operação (Rx ou Tx: 27mA@32MHz);

- Baixa corrente em modo de espera $(0.3 \mu \mathrm{A})$;

- Tensão de trabalho (2.0 a 3.6VDC), 250kbps, 2MChips/s, clock de 32MHz;

- Microprocessador compatível com 8051;

- Memória volátil e não volátil (128kB de flash, 8kB RAM);

- Periféricos:

- 21 pinos de entrada e saída genéricos;

- 8 conversores analógico-digitais de 12 bits cada;

- 1 timer de 16 bits e dois de 8 bits cada;

- 2 portas USART para comunicação serial;

- Monitoramento de tensão de alimentação e temperatura;

- Co-processador de hardware para criptografia AES 128 bits;

- 4 modos de gerenciamento de energia;

- Sistema de rastreamento implementado no próprio hardware.

O circuito também apresenta um detector de passagem por zero que informa ao microprocessador quando a tensão da rede elétrica passa pelo valor zero para que ele dispare o timer de 
16 bits, variando a saída PWM (Pulse Width Modulation) e controlando o tempo de fechamento do tiristor para a variação de potência na carga.

Alguns componentes de alta freqüência $(2.4 \mathrm{GHz})$ como um balun e a antena foram impressos diretamente na própria placa de circuito impresso. Essa técnica reduz o número de componentes externos, mas é diretamente dependente da qualidade e espessura do substrato da placa.

O desenho da placa está em acordo com as normas IPC-2221A e IPC-2222 (IPC, 1998) da Association Connecting Electronics Industries (APC) que recomenda $0.00508 \mathrm{~mm}$ de espaçamento entre trilhas para cada volt. No caso da fonte universal que trabalha com tensões de até 265VAC e, em alguns componentes, os picos de tensão podem alcançar 400V, foram respeitados os espaçamentos mínimos de $1.4 \mathrm{~mm}$ e $2 \mathrm{~mm}$, respectivamente.

\section{Sensores e Atuadores}

A lista de sensores e atuadores está a seguir. Para a escolha de cada um considerou-se aspectos como custo, tamanho e necessidades para a automação residencial.

Sensores:

- Sensor de temperatura, $-40^{\circ} \mathrm{C} \mathrm{a}+80^{\circ} \mathrm{C}$ (embutido no próprio microprocessador);

- Sensor de tensão da alimentação, 0 a 3.6 VDC (embutido no próprio microprocessador);

- Sensor de umidade relativa do ar, 0 a 100\% (HIH 5031) (HONEYWELL, 2009);

- Sensor de pressão atmosférica, 15 a 115 kPa (MP3H6115A) (FREESCALE, 2009b);

- Botão de pressão (liga-desliga sem trava, normalmente aberto);

- Potenciômetro, $270^{\circ}$ (variação linear);

- Sensor de presença infravermelho passivo, visão de 50 $3 \mathrm{~m}$ (IRS-A200ST01) (MURATA, 2009);

- Sensor de luminosidade, 1 a 100.000 lx (BH1603FVC) (ROHM, 2009);

- Sensor de aceleração de três eixos, +/-3g e +/- 11g (MMA7341L) (FREESCALE, 2009a);

Atuadores:

- Mini Led de indicação; 
- Tiristor para comutação (relê de estado sólido) e controle de potência em cargas com isolamento por meio de foto-acoplador, corrente máxima 12A (FKPF12N80) (FAIRCHILD, 2009);

\subsubsection{Firmware}

Um dos objetivos da construção do nó de controle foi demonstrar a viabilidade técnica e financeira de se monitorar ambientes de uma casa e controlar dispositivos de acionamento elétrico. Pelas razões apresentadas a seguir, as especificações ZigBee foram escolhidas para serem implementadas no firmware dos nós de controle propostos neste trabalho.

ZigBee é um pacote de especificações abertas (não-proprietárias) para comunicação sem fio, projetadas pelo consórcio ZigBee Alliance de modo a permitir a comunicação entre aparelhos sem fio de diferentes fabricantes (ZIGBEE, 2008). Esses padrões definem desde o hardware a ser utilizado na comunicação (o rádio IEEE 802.15.4, de baixa potência), até o protocolo para comandar a execução das ações próprias de cada tipo de aparelho, baseado no paradigma cliente/servidor. A existência de protocolos que permitem a interoperabilidade entre aparelhos de diferentes fabricantes e as características técnicas atraentes dos módulos ZigBee fazem dessa tecnologia um padrão muito promissor para automação residencial.

Todos os aparelhos de uma rede ZigBee utilizam o rádio digital IEEE 802.15.4 (IEEE, 2009), padrão específico para rádios de redes sem fio de banda estreita de transmissão. Em comparação com o Bluetooth (padrão IEEE 802.15.1), o padrão IEEE 802.15.4 é mais eficiente energeticamente, apesar de fornecer menores taxas de transmissão de dados (250 kbps). Os rádios IEEE 802.15.4 operam na frequiência global de $2.4 \mathrm{GHz}$ ou em outras frequiências específicas em certos países,

Outra característica importante do IEEE 802.15.4 é a possibilidade da formação de redes tipo malha (ou mesh, em inglês), em que dois rádios distantes entre si se comunicam utilizando rádios intermediários como retransmissores. Assim, o servidor de aplicação pode monitorar todos os aparelhos ZigBee de uma casa, mesmo que estes não estejam ao seu alcance direto.

As especificações ZigBee definem uma rede dinâmica, permitindo que aparelhos ZigBee entrem ou saiam dela quando requisitado. Existem três tipos de aparelhos no que se refere à operação da rede: o coordenador (coordinator), o roteador (router), e o aparelho final (end device). O coordenador é aquele que inicia a rede, definindo um número identificador de rede e o canal (frequiência específica) a ser utilizado para a comunicação, esperando que outros aparelhos se conectem a ele, podendo enviar ou receber dados dos mesmos. 
Semelhante ao coordenador, o roteador é um aparelho a que podem se conectar quaisquer outros, de modo a servir de rota para dados transmitidos entre aparelhos fisicamente distantes na rede. Por fim, um aparelho final pode se conectar a somente um roteador ou coordenador, não podendo, assim, retransmitir dados vindos de outros aparelhos, mas apenas receber e enviar dados ao roteador a que está conectado.

Um aparelho ZigBee comporta diversas aplicações, assim, uma luminária pode compartilhar o mesmo rádio com um sensor de presença e um sensor de luminosidade. Cada aplicação é acessada por meio de um identificador próprio, análogo às portas TCP em redes TCP/IP. Para enviar um comando e interagir com a aplicação é necessário enviar:

- Endereço do aparelho de destino;

- Identificador da aplicação de destino;

- Identificação de grupo do comando;

- Seqüência de bytes do comando propriamente dito.

A identificação de grupo de comando indica a funcionalidade a que o comando se refere: uma mesma seqüência de bytes pode corresponder ao comando para acender uma lâmpada ou ler um dado. No entanto, para garantir a interoperabilidade entre aparelhos de diversos fabricantes, a ZigBee Alliance definiu um conjunto de funcionalidades e seqüências de comandos para a troca de mensagens entre essas aplicações. Tais definições são conhecidas como ZigBee Cluster Library (ZCL) (ZIGBEE, 2007a).

A ZCL define diversos clusters, que são compostos por um conjunto de atributos e de comandos. A estrutura de um cluster obedece à arquitetura cliente/servidor: de modo geral, os aparelhos que implementam a parte cliente do cluster enviam comandos aos aparelhos que implementam a parte servidor. Por exemplo, o lado servidor do cluster On/Off, definido para a utilização em aplicações em que se liga ou desliga um aparelho, tem como atributo o estado do mesmo, que indica se ele está ligado ou desligado (uma luminária ZigBee, por exemplo). Os comandos enviados pelo lado cliente (um interruptor ZigBee), são de ligar, desligar, ou alternar o estado do aparelho.

Os perfis de aplicação (Application Profiles) descrevem como os clusters definidos na ZCL devem ser utilizados. Os perfis públicos (definidos pela própria ZigBee Alliance) disponíveis atualmente são: Home Automation e Smart Energy. Os perfis em estudo são: Health Care e Building Automation. O perfil adotado neste trabalho foi o Home Automation (HA) (ZIGBEE, 
2007b), que define os tipos de aparelhos a serem utilizados em uma aplicação de automação residencial ou comercial de pequeno porte.

\section{Nós de Controle}

As funcionalidades disponíveis no circuito elétrico do nó de controle definem quais aparelhos e perfis podem ser implementados. A seguir, a lista com os aparelhos do perfil Home Automation que podem ser implementados de acordo com as disponibilidades de hardware do nó de controle:

- Dimmer de luz, controlado por um potenciômetro

- Luz dimerizável, controlada por PWM (Pulse Width Modulation)

- Detector de presença

- Sensor de luminosidade

- Sensor de temperatura

- Sensor de pressão

Além desses aparelhos, foram criados outros, não previstos no perfil HA, de modo a permitir o acesso aos dados do acelerômetro por meio do protocolo ZigBee.

\section{Nó de Interface}

O nó de interface é responsável pela comunicação entre a rede ZigBee e um computador por meio de uma porta serial, também previsto pelo perfil HA.

Se, por um lado, os clusters ZCL que devem ser implementados nesse nó já estão especificados pelo perfil Home Automation, por outro a comunicação entre este e o computador não está pautada por nenhuma especificação, e teve que ser projetada e implementada desde o início.

Os requisitos definidos para esse protocolo de comunicação são:

- Permitir que o computador detecte, sob demanda, a presença do nó de interface conectado à porta serial e a presença de um nó específico na rede;

- Permitir que o nó de interface detecte, sob demanda, que o computador esteja conectado e com a interface em execução; 
- Permitir que o computador envie comandos a aparelhos ZigBee específicos na rede;

- Permitir que o computador receba comandos de aparelhos na rede ZigBee.

Esse protocolo foi criado de modo a certificar que o dado enviado do computador para o nó de interface ou vice-versa é válido, bem como certificar que eles estão conectados entre si, com o software de interface em execução normal. Por isso, os pacotes trocados estão estruturados para permitir uma simples verificação de erro e garantir que o aparelho (computador ou nó de interface) recebeu o pacote corretamente. Como existem apenas dois aparelhos, não foi necessário elaborar nenhuma política de acesso ao meio. A Figura 14 ilustra a estrutura do pacote de dados trocado entre o computador e o nó.

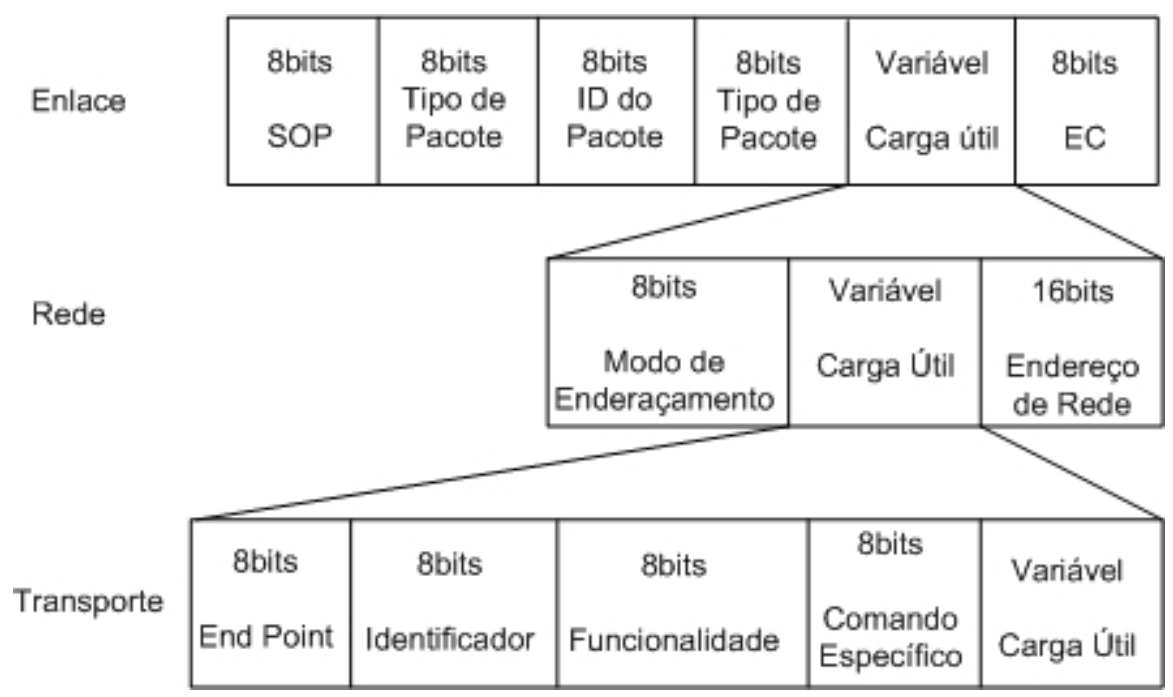

Figura 14: Pacote de dados para a comunicação serial

O pacote possui um cabeçalho composto por um byte SOP (Start of Packet), constante, que marca o início de um pacote (aqui, SOP = 2), um byte indicando o tipo de pacote transmitido e outro byte indicando o tamanho da carga útil. Há três tipos de pacotes definidos:

- NWK - Pacote de rede (tipo 0)

- ACK REQ - Pacote de requisição de reconhecimento (tipo 1)

- ACK - Pacote de reconhecimento (tipo 2)

No fim do pacote, existe um byte de correção de verificação de erro (EC). Ele é resultado da operação de XOR seqüencial de todos os bytes do pacote, exceto o primeiro e o último. Na recepção do pacote, é feita novamente uma checagem: se o byte gerado por esse procedimento for igual ao recebido, o pacote é considerado correto. 
Quanto aos tipos de pacote, os pacotes de rede (NWK) são aqueles que carregam datagramas de rede como carga útil, vindos de outro aparelho ZigBee ou do próprio nó de interface. Os pacotes ACK REQ são petições para checar a presença do aparelho no outro terminal da porta de comunicação. Quando um desses aparelhos (computador ou nó de interface) recebe corretamente qualquer um desses dois tipos de pacote, deve responder com um pacote de reconhecimento (ACK), como forma de confirmar o recebimento. Caso algum aparelho não receba essa confirmação dentro de um tempo pré-especificado, re-envia o pacote por até duas vezes.

\subsection{Gerenciador Residencial}

O Gerenciador Residencial é responsável pela operação de toda a infraestrutura de software. Ele controla e monitora as atividades dos demais programas, verifica a comunicação entre eles e reporta falhas. Os módulos que o compõe são:

- Módulo de Rede: responsável pela comunicação do servidor com o mundo externo por meio do protocolo TCP/IP. É por ele que transitam as informações para a interface com o usuário.

- Módulo de Registro: responsável em gerenciar e armazenar informações sobre o funcionamento dos outros programas.

- Módulo de Relógio: responsável por gerar e atualizar as informações de hora e data, e manter a sincronia em programas que dependam de impulsos externos como, por exemplo, o módulo de registro.

- Gerenciador de Memória: responsável pelo armazenamento e acesso de informações em banco de dados. Para o armazenamento de eventos da residência e de informações de contexto é utilizado um banco de dados relacional e persistente. Para o armazenamento de dados de acesso rápido, como, por exemplo, eventos recém chegados, são utilizados listas e vetores disponíveis pela própria plataforma Java.

- Módulo de Comunicação Serial: responsável pelo funcionamento das portas seriais do computador, por especificar os parâmetros de transmissão e recepção, e gerenciar a comunicação com o nó de interface.

- Módulo de Configuração: responsável por ler arquivos, carregar configurações, etc. 


\subsection{Gerenciador de Eventos}

O Gerenciador de Eventos recebe todos os eventos gerados na residência, sejam eles oriundos da interface gráfica do usuário ou da rede de sensores, insere uma marcação temporal e os disponibiliza para análise. Uma cópia dessa informação ele solicita que seja armazenada no banco de dados e a outra envia para o Gerador de Contexto de Primeira Ordem.

\subsection{Descrição das Interfaces de Programa}

Em sistemas computacionais, interfaces de programa (API - do inglês Application Programming Interface), como o próprio nome diz, são interfaces que definem como um programa pode requisitar serviços de outros programas (e.g. bibliotecas, sistemas operacionais, etc.). A API define um vocabulário e algumas convenções que devem ser usadas por quem deseja fazer uso dos serviços sem que haja a necessidade de conhecerem detalhes técnicos do software. Esse fato, geralmente, reduz a probabilidade de algum algoritmo malicioso provocar algum dano ao sistema ou corromper algum dado.

O Home Sapiens disponibiliza três interfaces de programa:

- API de Serviço;

- API de Contexto;

- API de Sistemas de Controle;

É válido notar que a residência deixou de ser uma entidade puramente física para ser também uma entidade lógica, cujas regras são determinadas por programas computacionais. Quem desejar criar um equipamento compatível com a arquitetura proposta deve desenvolvê-lo por meio de um processo semelhante ao utilizado no segmento de fabricação de computadores e periféricos: criar o hardware do produto com transdutores e interface de rede; desenvolver o software de serviço que disponibilizará os atributos físicos do produto no ambiente computacional; criar um programa de controle e uma aplicação para que o usuário usufrua do produto. A API de Contexto é especializada para a criação de novos mecanismos de geração e análise de informação de contexto. 


\subsection{Gerenciador de Contexto}

O Gerador de Contexto de Primeira Ordem é responsável por analisar os eventos e disponibilizar informações sobre o local da ação, identidade do objeto ou pessoa que realizou a ação, o estado atual dessa entidade e a data que ocorreu o evento. Essas informações são armazenadas no banco de dados para serem analisadas pelo Gerador de Contexto de Ordem Superior.

A API de Contexto disponibiliza as seguintes informações e procedimentos:

Espaço:

- A lista de todos os espaços;

- Criação ou exclusão de um espaço;

- Dado um espaço, qual o valor de seus atributos (coordenadas, cor, tipo);

- Dado um espaço, quais são seus espaços adjacentes;

- Dado um espaço, quais são suas entidades (usuários ou objetos);

Eventos:

- Dado um evento, qual o valor de seus atributos (dispositivo, data, espaço, entidade);

- Exclusão de um evento;

- Dado um evento, qual sua duração;

- Dados dois eventos, qual ocorreu primeiro;

Identificação:

- A lista total de entidades;

- Criação ou exclusão de uma entidade;

- Dada uma entidade, qual o valor de seus atributos (tipo, nome);

Data:

- Dado um período, quais eventos aconteceram; 
Gerador de Contexto:

- A lista de todos os geradores;

- Criação ou exclusão de um gerador;

- Adição ou remoção da lista do gerenciador;

- Dado um gerador, qual o valor de seus atributos (tipo, mensagens, serviços);

- Dado um gerador, a lista dos provedores de informação;

- Dado um gerador, a lista dos receptores de informação;

- Dado um gerador, a lista de tópicos de interesse;

Mensagens de Contexto:

- Dado um gerador, a lista de todas as mensagens;

- Criação ou exclusão de uma mensagem;

- Dada uma mensagem, qual o valor de seus atributos (versão, tipo, tamanho);

Tópicos:

- A lista de todos os tópicos de interesse;

- Criação ou exclusão de um tópico de interesse;

- Dada um tópico, quais são seus atributos (versão, tipo, nível);

\subsection{Sistemas de Controle}

A arquitetura descrita nesse trabalho sugere que as decisões sejam efetuadas pelos sistemas de controle. Essa abordagem facilita o desenvolvimento de algoritmos por terceiros e mantém organizada a estrutura mostrando com mais clareza as responsabilidades de cada sistema. No entanto, isso pode dar a falsa impressão de uma tendência ao modelo orientado a serviços em detrimento do orientado ao contexto, o que seria um ponto crítico em uma plataforma genérica de desenvolvimento. O fato é que o Gerenciador Residencial provê aos sistemas de controle 
acesso à base de dados e às informações geradas pelos módulos de contexto e o desenvolvedor pode (e se sugere que o faça) usar esses recursos adicionais para reduzir as incertezas no processo de decisão.

A figura do Arbitrador estabelece uma política baseada em níveis de prioridades caso não haja concordância nas ações escolhidas pelos sistemas de controle. Por exemplo, é provável que as ações do Sistema de Detecção e Combate a Incêndios tenham maior prioridade que as do Sistema de Iluminação, mas talvez não seja interessante manter essas regras imutáveis e permitir que o programador as altere quando achar necessário. Uma vez determinada a ação, uma cópia é enviada ao conversor de sinais para, posteriormente, alcançar o respectivo nó de controle e seu atuador. A outra cópia é enviada ao banco de dados para seu armazenamento.

A API de Sistemas de Controle disponibiliza as seguintes informações e procedimentos:

Sistemas:

- A lista de todos os sistemas;

- Dado um sistema, qual o valor de seus atributos;

- Dado um sistema, efetue a mudança de seus atributos;

- Dado um sistema, efetue a adição ou remoção de um mecanismo de controle;

- Dado um sistema, quais são seus mecanismos de controle;

Mecanismos de controle:

- A lista de todos os mecanismos de controle;

- Criação ou a remoção de um mecanismo de controle;

- Dado um mecanismo de controle, qual o valor de seus atributos;

- Dado um mecanismo de controle, efetue a mudança de seus atributos;

Arbitrador:

- A lista de todas as regras;

- Dada uma regra, qual o valor de seus atributos; 


\subsection{Serviços}

A API de Serviços disponibiliza as seguintes informações e procedimentos:

Serviços:

- A lista de todos os serviços;

- Criação ou exclusão de um serviço;

- Dado um serviço, qual o valor de seus atributos;

- Dado um serviço, efetue ou cancele seu ativamento;

- Dado um serviço, quais são seus dispositivos;

- Dado um serviço, efetue a adição ou remoção de um dispositivo;

Dispositivos:

- A lista de todos os dispositivos;

- Criação ou a exclusão de um dispositivo;

- Dado um dispositivo, qual o valor de seus atributos;

- Dado um dispositivo, efetue ou cancele seu ativamento;

- Dado um dispositivo, quais são seus transdutores;

- Dado um dispositivo, efetue a adição ou remoção de um transdutor;

Transdutores:

- A lista de todos os transdutores;

- Dado um transdutor, qual o valor de seus atributos;

- Criação ou a exclusão de um transdutor;

- Dado um transdutor, efetue ou cancele seu ativamento; 


\subsection{Interface Gráfica do Usuário}

A interface gráfica do usuário também é um programa computacional, desenvolvido em Java, mas é executada externamente ao servidor de aplicação. Sua conexão com o servidor se estabelece por meio da Internet e, dessa forma, permite ao usuário monitorar e controlar sua residência remotamente. Esse desacoplamento é importante não só pela comodidade do gerenciamento remoto, mas porque permite que vários modelos sejam desenvolvidos, com diferentes níveis de detalhamento, de acordo com hardware (computador, celular, smart phone, etc.) e com o perfil do usuário que irá utilizá-la.

As Figuras 15 e 16 ilustram a interface em funcionamento. Inicialmente, o usuário executa o programa e insere o endereço da Internet do servidor de aplicação. O servidor estabelece a comunicação e começa a enviar continuamente as informações sobre o estado de sensores e atuadores. Cada cômodo da casa automatizada é apresentado na interface por meio da sua vista superior. Essa visão permite identificar de imediato o comportamento de cada transdutor e se há algum equipamento requisitando a atenção do usuário. Vale notar que além dos sensores, os atuadores também acusam sua mudança de estado, abrindo e fechando no caso das portas, janelas, cortinas e portão da garagem e alterando de cor, no caso das lâmpadas.

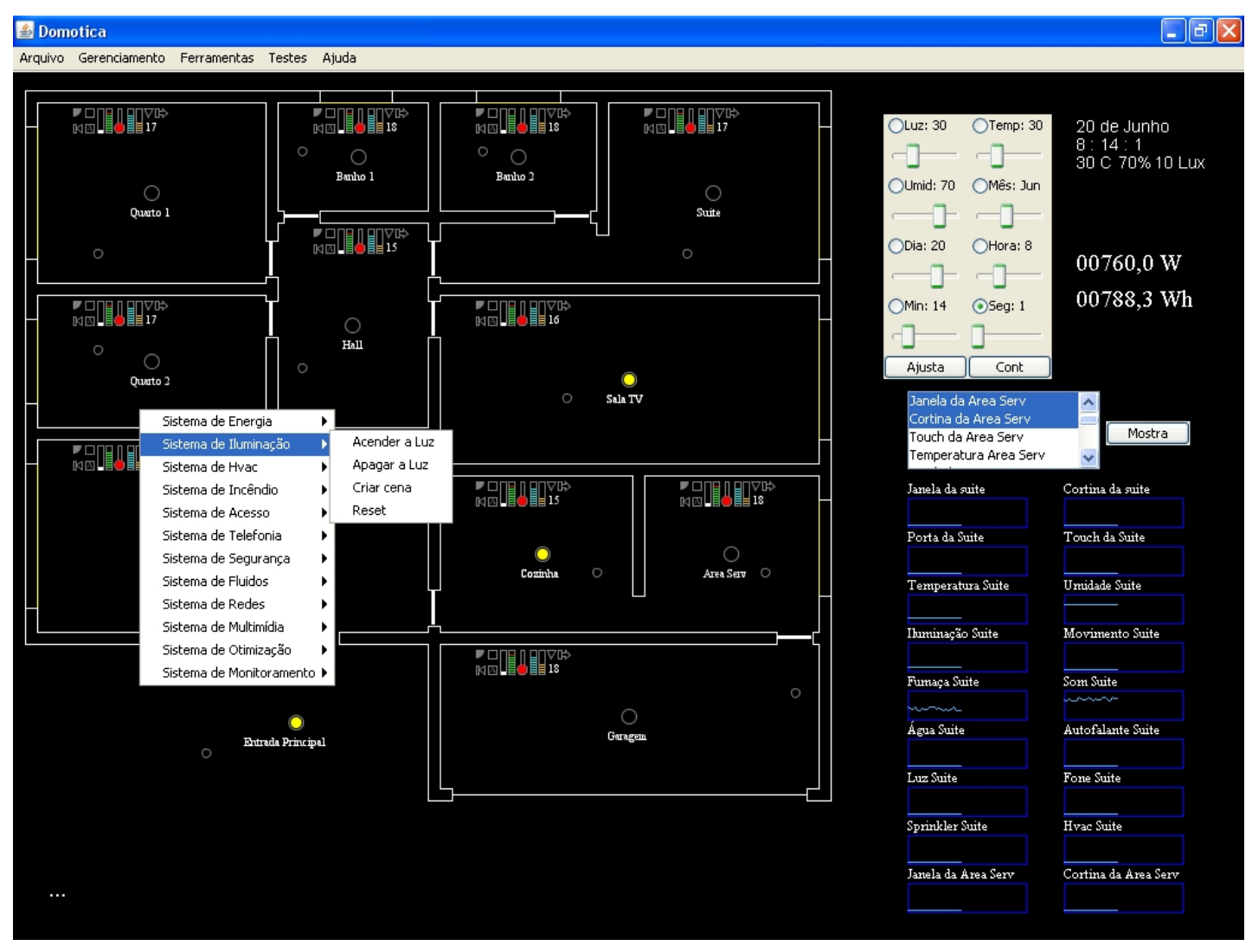

Figura 15: Interface gráfica do Home Sapiens 


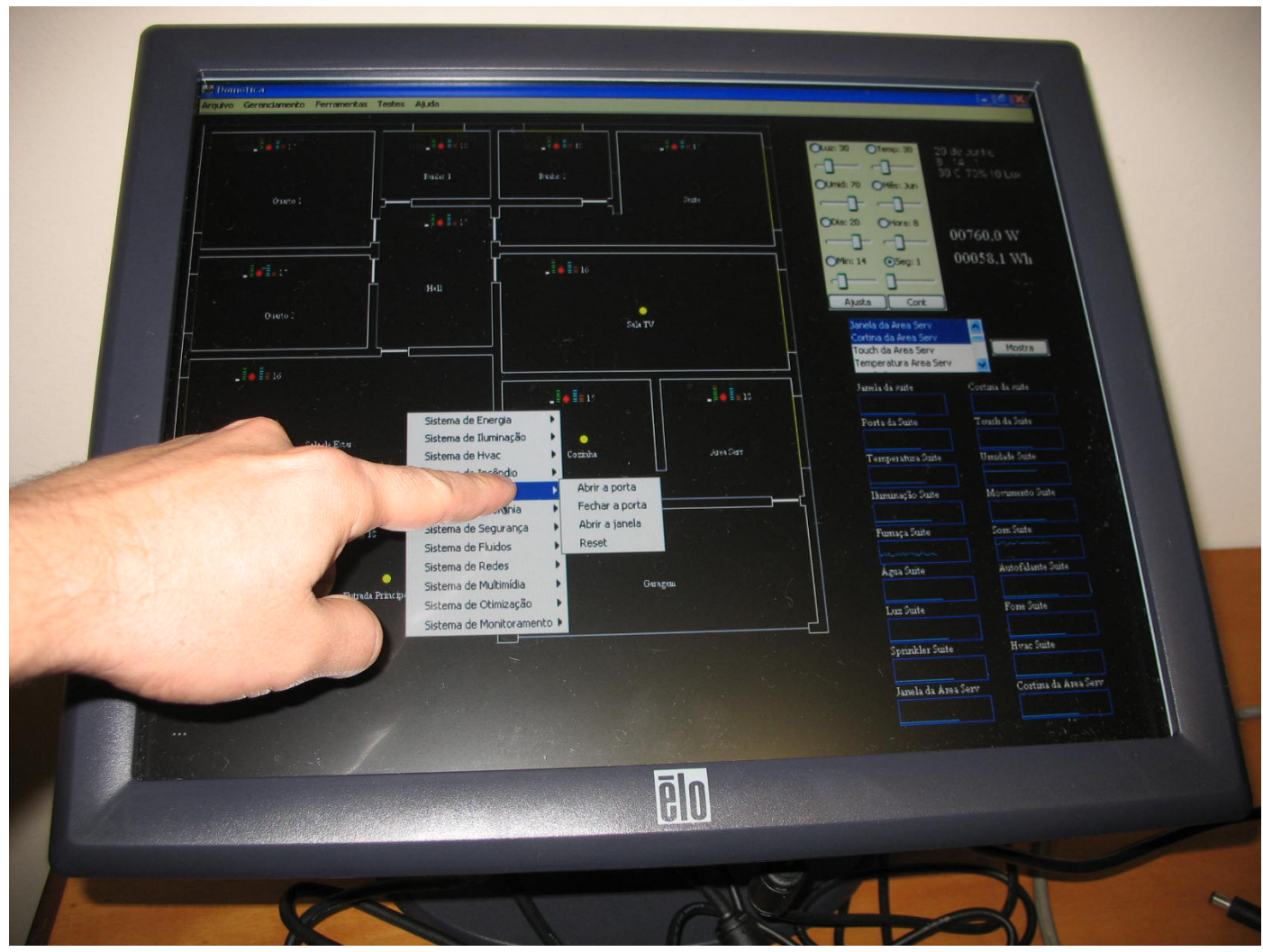

Figura 16: Interface gráfica sendo utilizada em uma tela de toque

A interface disponibiliza um menu para o envio de comandos aos sistemas de controle. Basta tocar no menu sobre o cômodo desejado e o sistema procura no banco de dados qual nó de controle está associado a ele e envia o comando para alterar o estado do atuador.

A interface com o usuário é composta por seis módulos:

- Módulo Central: responsável pela execução da interface e por gerenciar as atividades dos outros;

- Módulo de Rede: responsável pela comunicação da interface com o servidor por meio do protocolo TCP/IP;

- O módulo de sistemas de controle é uma representação dos sistemas do servidor para a geração de eventos;

- Módulo Gráfico: controla a aparência e o comportamento das entidades gráficas na tela;

- Módulo de Registro: responsável por gerar e armazenar informações sobre o funcionamento dos outros módulos;

- Módulo de Configuração: responsável por ler arquivos, carregar configurações, etc. 
A interface gráfica foi criada totalmente separada dos módulos gerenciadores, no que diz respeito à dependência de linguagem de programação e sistema operacional. Essa prática reduz a dependência entre esses módulos, uma vez que não há a transmissão de objetos ou qualquer outro tipo de estrutura dependente de linguagem computacional. Isso permite que novas interfaces sejam criadas utilizando-se outros dispositivos com diferentes sistemas operacionais como telefones celulares, por exemplo, e espera-se que apenas se obedeça as regras de sintaxe das mensagens enviadas para que seja possível o controle e monitoramento remotos da residência.

\subsection{Considerações Finais}

No desenvolvimento da plataforma considerou-se a decomposição de sistemas complexos em módulos mais simples, cada um com suas funções, responsabilidades e protocolos de entrada e saídas de dados. A divisão em módulos ou camadas é uma técnica muito utilizada por arquitetos de software e, no caso do Home Sapiens, permite que vários desenvolvedores possam trabalhar concomitantemente desenvolvendo novos módulos de acordo com a disponibilidade de hardware existente ou mesmo criando melhorias ou adaptando os módulos às suas necessidades.

Outra técnica adotada foi a utilização de um padrão de programação conhecido como observer ou muitas vezes por publish/subscribe. No Home Sapiens, a maioria dos módulos depende de informações de outros módulos para operarem. Utilizando o padrão observer, cada módulo efetua seu registro para receber atualizações dos eventos gerados pelos outros módulos mantendo uma dependência um-para-muitos entre objetos distintos, que serão notificados da mudança de estado do objeto observado.

O uso desses mecanismos provêem ao Home Sapiens uma redução na dependência entre os módulos, de forma que os algoritmos contidos em cada um deles possam ser modificados e testados sem afetar o funcionamento do conjunto. Esse é fator importante em se tratando de uma plataforma deste tipo, onde há grande probabilidade de cada desenvolvedor ajustar apenas os módulos que acharem conveniente. 


\section{$7 \quad$ Testes e Análises dos Resultados}

Alguns experimentos foram realizados para testar o funcionamento do Home Sapiens. Em primeiro lugar, o conjunto formado pelo hardware e firmware foi submetido a testes. Então, testou-se todo o sistema, incluindo o software.

\subsection{Testes do Hardware e do Firmware}

Os testes do hardware e do firmware objetivaram verificar:

- Adequação do protocolo de comunicação entre o computador e a rede ZigBee;

- A correta comunicação entre os nós da rede;

- A correta execução dos comandos pela aplicação implementada nos nós da rede

Para testar o funcionamento da troca de comandos para identificação das aplicações na rede, foi montada uma rede com um nó de interface e um nó de controle, conforme mostrado na Figura 17.

O nó de interface possui três tipos de aplicativos:

- Combined Interface, do perfil HA que gerencia a comunicação entre o computador e a rede;

- Generic Application, usado para tratar mensagens;

- Dimmable Light, do perfil HA, que funciona como uma lâmpada dimerizável virtual, retransmitindo ao computador os comandos recebidos de um potenciômetro.

Antes de iniciar a comunicação entre o computador e os nós rede ZigBee, é necessário realizar uma troca de comandos iniciais que revelem quais aparelhos estão conectados na rede e quais as aplicações disponíveis em cada um. Para tanto, é preciso primeiro que o servidor de aplicação reconheça a presença do nó de interface conectado à porta serial do computador. Há dois modos de se saber quais os outros aparelhos da rede: 


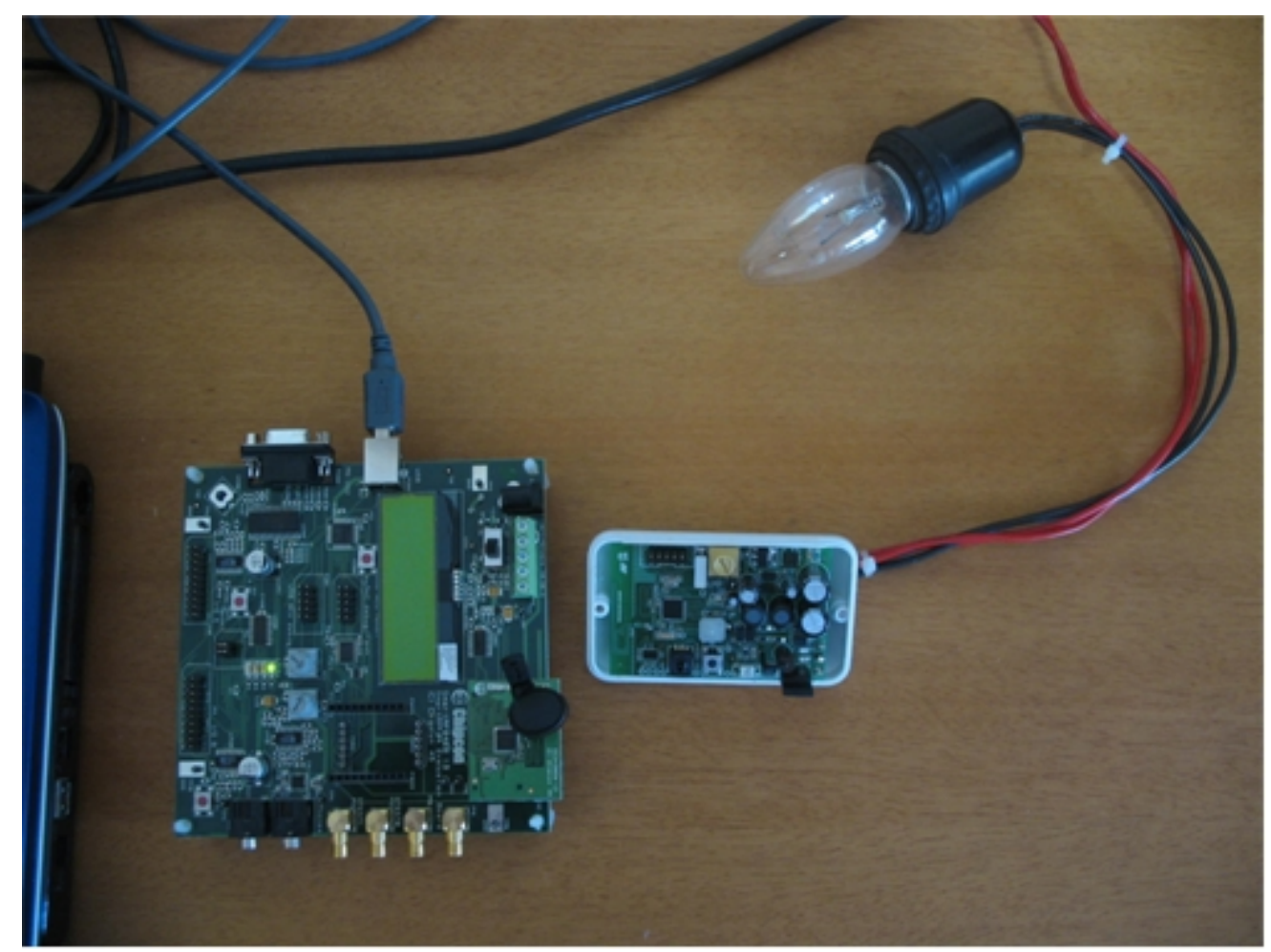

Figura 17: Detalhes do nó de interface e nó de controle

- Os aparelhos devem anunciar a sua entrada na rede a todos os demais;

- Requisitar a um roteador quais os endereços de rede de seus aparelhos.

A Figura 18 mostra os resultados dos testes da comunicação realizada para a descoberta das aplicações na rede. O lado esquerdo mostra a interface Java com a lista de End Points implementados após verificar a conexão com o nó de interface, receber a informação da entrada do outro nó (de controle) na rede, e requisitar de ambos os números dos End Points implementados. O lado direito mostra as aplicações implementadas após requisitar de cada End Point o descritor de tipo de aparelho.

\subsection{Teste do Sistema}

Uma vez verificada a correta comunicação entre o computador e os nós da rede, intermediada pelo nó de interface, efetuou-se o teste da plataforma completa. O primeiro teste realizado foi o da leitura dos sensores e da requisição do envio periódico dos valores. A Figura 19 mostra os resultados obtidos.

Então, foi testado o envio do nível indicado pela interface para o nó de controle. Para tanto, foi feita uma ligação (binding) entre a lâmpada dimerizável virtual implementada no nó 


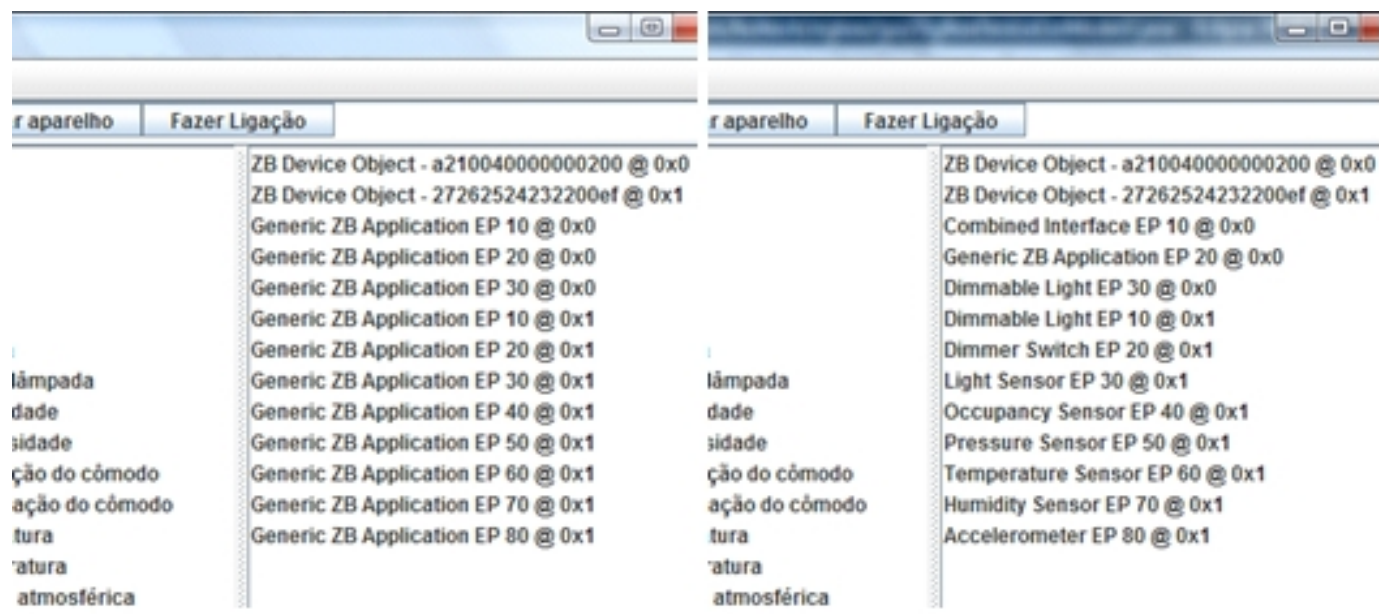

Figura 18: Teste da comunicação serial

\begin{tabular}{|c|c|c|}
\hline \multicolumn{3}{|c|}{ Interface rede ZigBee } \\
\hline \multicolumn{3}{|c|}{ File Edit Port Help } \\
\hline Enviar Cmd & Verificar aparelho & igaçào \\
\hline \multicolumn{2}{|c|}{$\begin{array}{l}\text { Requisitar Aparelhos Filhos } \\
\text { Requisitar End Points } \\
\text { Requisitar Tipo de Aparelho } \\
\text { Identificar por } 5 \text { segundos } \\
\text { Ligar Låmpada } \\
\text { Desligar Lämpada } \\
\text { Alternar estado đa lâmpada } \\
\text { Definir nivel de potência da lảmpada } \\
\text { Requisitar nivel de luminosidade } \\
\text { Subscrever nivel de luminosidade } \\
\text { Requisitar estado de ocupação do cómodo } \\
\text { Subscrever estado đe ocupaçăo đo cómodo } \\
\text { Requisitar valor da temperatura } \\
\text { Subscrever valor da temperatura } \\
\text { Requisitar valor da pressão atmosférica } \\
\text { Subscrever valor da pressão atmosférica } \\
\text { Requisitar valor da umidade relativa } \\
\text { Subscrever valor da umidade relativa } \\
\text { Requisitar valor } 30 \text { da aceleração } \\
\text { Subscrever valor 3D da aceleração }\end{array}$} & $\begin{array}{l}\text { ZB Devi } \\
\text { ZB Devi } \\
\text { Combin } \\
\text { Generic } \\
\text { Dimmat } \\
\text { Dimmat } \\
\text { Dimmer } \\
\text { Light Se } \\
\text { Occupa } \\
\text { Pressur } \\
\text { Temper } \\
\text { Humidit } \\
\text { Acceler }\end{array}$ \\
\hline \multicolumn{3}{|c|}{ Insira o texto a ser mostrado no LCD đo nó de interface } \\
\hline $\begin{array}{l}\text { Porta COM9 abe: } \\
\text { Luminosidade } 1 \\
\text { Cómodo desocu } \\
\text { Temperatura } 126 \\
\text { Pressão Atmoste } \\
\text { Umidade relativa } \\
\text { Vetor de acelera }\end{array}$ & $\begin{array}{l}53 \mathrm{~lx} \\
\text { ado } \\
\text { BC } \\
\text { ica } 126.8 \mathrm{kPa} \\
126.8 \% \\
\text { (12.68,12.68,12.68)G }\end{array}$ & $=$ \\
\hline
\end{tabular}

Figura 19: Teste da leitura dos sensores 
de interface (à esquerda, usando o kit de desenvolvimento da Texas Instruments) e a aplicação de dimmer implementada no nó de controle (placa menor, à direita), usando uma escala linear de 0 a $100 \%$, como mostrado na Figura 20.
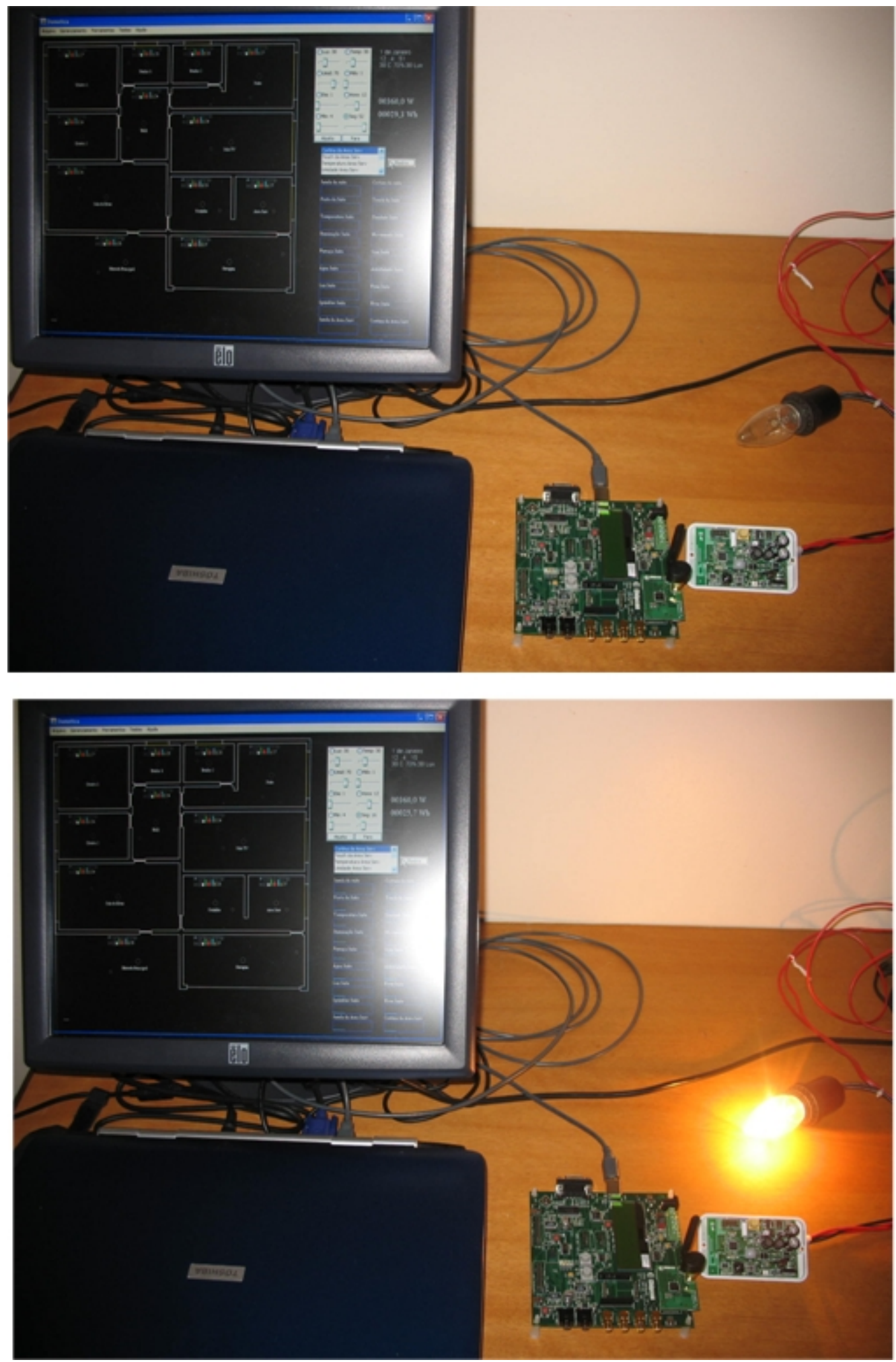

Figura 20: Teste do sistema completo 


\subsection{Análise dos Resultados}

O uso de nós de controle interligados por uma rede sem fio apresenta importantes vantagens em relação aos sistemas centralizados e cabeados. A facilidade de instalação em relação ao custo talvez seja a mais relevante de todas. Nos testes, em alguns minutos, os nós já estavam operacionais, transmitindo e recebendo mensagens. Neste trabalho, a interferência eletromagnética de outras fontes operando na mesma frequência $(2.4 \mathrm{GHz})$ como, por exemplo, telefones sem fio, roteadores Wi-Fi ou mesmo fornos de microondas não foi objeto de estudo, mas, a principío, a conexão entre os nós não se mostrou prejudicada por este motivo. No entanto, a obstrução devido ao fechamento de portas ou à movimentação de pessoas causou instabilidade no sistema e o número de pacotes perdidos aumentava substancialmente devido a esses eventos.

A utilização de um meio de transmissão não confiável, em que não há a certeza que um pacote tenha sido entregue ou ainda quando ocorre a situação que um nó inteiro não esteja disponível, gera uma grande quantidade de código computacional para identificar e tratar as exceções. Em um sistema de controle, os módulos de gerenciamento devem sempre estar cientes dos estados dos atuadores para que não haja problemas na lógica de controle. Eles ainda devem ser capazes de manter todo o sistema em um estado seguro em caso de pane. A dificuldade neste caso está em como identificar qual o grau de seriedade da pane e como administrá-la. A inserção de verificadores de estado, temporizadores e outros artifícios computacionais foram utilizados para detectar essas exceções, mas a divisão das responsabilidades em módulos e a atribuição de tarefas, de acordo com o contexto vigente, foram preponderantes para organizar o fluxo de informações e deverão facilitar o desenvolvimento futuro de novos algoritmos e sistemas de controle residenciais.

O alto nível de miniaturização do microprocessador/rádio e dos transdutores possibilitou a criação de um nó de controle com dimensões apropriadas para o uso residencial, seja em caixas de passagem ou sobre forros. Em equipamentos móveis, alimentados por baterias, a fonte de alimentação 80-240VAC pode ser descartada, o que reduz significamente o tamanho do nó. A opção pela antena em formato de $F$, construída na própria placa, teve como objetivo principal a redução de custo, mas a relação ganho versus custo é um aspecto importante que deve ser analisado, pois existem no mercado outros modelos de antenas, coaxiais e em pastilhas, com alta integração física, alto ganho e com um custo que pode ser apropriado à aplicação desejada.

Finalmente, a utilização de um computador pessoal como controlador da residência é um ponto delicado do Home Sapiens. O fato de se disponibilizar um computador para essa função não é o maior problema, pois é natural esperar que uma residência utilize um computador para gerenciar e armazenar conteúdo multimídia. Neste caso, o programa gerenciador poderia ser 
instalado neste mesmo equipamento. A questão crítica é que os computadores pessoais são máquinas complexas e mais susceptíveis a panes e erros do que os nós de controle. Centralizando nele todo o controle da residência, a probabilidade de mau funcionamento e panes aumenta substancialmente.

Essa arquitetura foi escolhida segundo dois aspectos importantes: o relativo baixo poder computacional dos módulos e a facilidade de programação dos algoritmos de controle utilizando-se uma linguagem de programação computacional de alto nível como o Java, C++ ou C\#. O Home Sapiens foi criado para ser uma plataforma de desenvolvimento e não um sistema computacional de produção, comercial. Sendo assim, é importante analisar futuramente a importância de migrar ou não os algoritmos de controle para os nós descentralizando o sistema e reduzindo o efeito indesejado da centralização, como mencionado anteriormente. 


\section{Conclusão}

A Domótica é uma ciência recente e envolve o estudo de diversas outras áreas do conhecimento. Dessa forma, a principal contribuição deste trabalho é o estabelecimento de formalismos e da taxonomia necessários para o entendimento dos conceitos que envolvem as residências inteligentes.

Observou-se que o desenvolvimento de equipamentos de controle residenciais utilizando abordagens tradicionais, focadas exclusivamente em aspectos técnicos, não disseminou o uso destes equipamentos. Assim, este trabalho também disponibiliza uma análise - social, econômica, tecnológica, cultural e de saúde - da sociedade, desde o início do século XX até os dias atuais, para entender o comportamento humano relativo ao ambiente residencial e identificar as possíveis causas que não favoreceram a implantação de sistemas de automação nestes ambientes.

A viabilidade tecnológica da utilização de sistemas eletrônicos de monitoramento e controle no ambiente residencial foi validada por meio da especificação de uma arquitetura de sistemas para residências inteligentes e da criação da plataforma Home Sapiens, considerando o estado da arte de transdutores, redes de comunicação e de dispositivos computacionais.

Outro ponto importante são as oportunidades oferecidas nesse século, descritas e discutidas ao longo deste trabalho, e que, segundo os registros históricos, apresentam uma inigualável capacidade de impulsionar o desenvolvimento do mercado de automação residencial, incluindo equipamentos e serviços. O panorama socioeconômico, cultural, ambiental e de saúde do século XXI, abordado no Cap. 2, evidencia a necessidade pelos sistemas residenciais inteligentes sendo plausível considerá-los como um conjunto de ferramentas para prover um maior bem estar às pessoas com o mínimo impacto energético, amplificando as interações dos moradores com a residência e provendo auxílio especial a idosos, crianças e pessoas com deficiência. Nesse sentido, a proposta de uma arquitetura de sistemas e o desenvolvimento de uma plataforma oportunamente contribuem para o desenvolvimento da área. 


\subsection{Trabalhos Futuros}

O Home Sapiens é uma plataforma de desenvolvimento de sistemas residenciais e abre inúmeras oportunidades no desenvolvimento de pesquisas em diversas áreas do conhecimento humano. Além de auxiliar a implantação de novos sistemas, ele possibilita o desenvolvimento de testes no próprio ambiente. Dentre as possíveis abordagens de estudo, podemos destacar:

\section{Aspectos Tecnológicos}

- Sistemas de Controle: O Home Sapiens utiliza um sistema reativo em conjunto com as informações de contexto para controlar os atuadores da residência. A implantação de novos módulos com outros métodos de controle, por exemplo, P, PI, PID, Fuzzy, IA, etc., e a criação de simuladores e/ou analisadores de performance destes algoritmos são fundamentais no processo de desenvolvimento de sistemas de controle residenciais;

- Geração de Contexto: os geradores de contexto são diretamente dependentes das informações do ambiente e dos usuários fornecidas pelos sensores e interfaces. Novos métodos de geração e análise dessas informações devem ser criados para enriquecer o conhecimento que o sistema tem da residência e, assim, melhorar a segurança e o conforto de seus moradores;

- Nós de Controle e Rede Doméstica: a qualidade das informações que acessam os sistemas de controle dependem da qualidade dos sensores disponíveis no nó de controle e da rede de comunicação. Por isso, é apropriado o estudo e teste de novos transdutores e o aprimoramento de protocolos de comunicação em dispositivos com restrições computacionais. Os aspectos relacionados à segurança dos dados também são relevantes uma vez que informações privadas dos moradores trafegam tanto internamente quando externamente à residência, e seu acesso indevido é extremamente indesejado;

- Interfaces com Usuário: a Computação Ubíqua enfatiza o desenvolvimento das interfaces humano-máquinas, pois a facilidade de interação entre o morador e o residência é imprescindível para o sucesso dos ambientes ubíquos. São várias as possibilidades de desenvolvimento nesta área: interfaces adaptáveis a usuários com necessidades especiais, aumento da qualidade da interface por meio da utilização de tecnologias gráficas tridimensionais, utilização de agentes virtuais para a criação de assistentes pessoais e uso de biometria para interação entre o usuário e os diversos dispositivos eletrônicos instalados na casa.

\section{Aspectos Ambientais}


- Energia e Demanda de Recursos: conforme visto neste trabalho, o controle residencial é uma ferramente importante para o uso racional de energia e controle de demanda. A plataforma Home Sapiens pode ser utilizada para o desenvolvimento de mecanismos de controle de demanda de recursos, para a criação de métodos de avaliação e medição de desempenho energético de residências e de seus equipamentos, e para a análise de utilização de fontes alternativas de energia;

\section{Aspectos Financeiros}

- Estudo de viabilidade financeira da implantação de módulos de controle e sistemas computacionais em residências.

\section{Aspectos Humanos}

- Estudo do impacto social relativo à imersão de pessoas em ambientes computacionalmente ativos;

- Estudo do comportamento humano para o desenvolvimento de novas interfaces;

- Estudo de tecnologias de comunicação e de ambientes virtuais como ferramentas de integração social;

- Desenvolvimento de métodos de análise de pós ocupação por meio da observação e exame de eventos;

\section{Aplicações}

- Desenvolvimentos de novos mecanismos de controle de conforto térmico.

- Integração de tecnologia de identificação de radiofreqüência (RFID), reconhecimento facial e de gestos com os gerenciadores de contexto para a personalização das funções da residência por meio da identificação do usuário.

- Desenvolvimento de sistemas de monitoramento de crianças, idosos e pessoas com deficiência;

- Desenvolvimento de sistemas de home care;

- Desenvolvimento de sistemas de alerta áudio-visual. 


\section{GLOSSÁRIO}

Home Sapiens Plataforma computacional e eletrônica para o desenvolvimento de sistemas de controle e interfaces humano-máquina residenciais.

Computação Pervasiva Ver Computação Ubíqua. Não existe atualmente um aspecto prático em se criar uma diferenciação entre os termos Computação Pervasiva e Ubíqua.

Computação Ubíqua Termo criado por Mark Weiser que propõe um modelo de interação pós-computador pessoal de mesa em que as pessoas irão viver rodeadas de dispositivos eletrônicos e interagir constantemente com o mundo virtual por meio de múltiplas interfaces.

Redes de Sensores sem Fio É uma rede que consiste de dispositivos (ou nós) distribuídos espacialmente, que utilizam sensores para monitorar condições físicas ou ambientais. Os nós comunicam-se com um equipamento que fornece uma conexão com o mundo externo onde há a possibilidade de medir, processar, analisar e apresentar os dados coletados.

Sistemas de Controle Residenciais São algoritmos computacionais que analisam as informações provenientes de sensores e interfaces, e atuam no ambiente, modificando o estado de atuadores.

ZigBee Conjunto de protocolos de comunicação para redes pessoais sem fio (WPAN - Wireless Personal Area Networks) criado pela Philips e posteriormente gerenciado pela ZigBee Alliance, operando sobre o padrão 802.15.4 do IEEE (Institute of Electrical and Electronics Engineers). 


\section{REFERÊNCIAS}

AARTS, E. Ambient intelligence: Building the vision. In: RUYTER, B. (Ed.). 365 days Ambient Intelligence Research in HomeLab. [S.1.]: Philips Research, 2003. p. 2-5.

ABOWD, G.; ATKESON, C.; ESSA, I. Ubiquitous smart spaces. A white paper submitted to DARPA, 1998.

ABOWD, G.; STERBENZ, J. Final report on the inter-agency workshop on research issues for smart environments. Personal Communications, IEEE [see also IEEE Wireless Communications], v. 7, n. 5 SN - 1070-9916, p. 36-40, 2000.

ALDRICH, F. Smart homes: Past, present and future. In: HARPER (Ed.). Inside the Smart Home. [S.1.]: Springer Verlag, 2003. p. 17-39.

ANATEL. Diretrizes Para Limitação Da Exposição a Campos Elétricos, Magnéticos E Eletromagnéticos Variáveis No Tempo (Até 300 GHz). [S.1.], 1999.

APPLE. Apple Iphone Mobile Phone, Ipod and Internet Device. 2008. Disponível em http://www.apple.com/iphone/. Acessado em 2009.

BANDINI, S.; MANZONI, S.; SIMONE, C. Heterogeneous agents situated in heterogeneous spaces. Applied Artificial Intelligence: An International Journal, v. 16, n. 9, p. 831-852, 2002.

BASTEN et al. Scaling into ambient intelligence. Design, Automation and Test in Europe Conference and Exhibition, n. SN - 1530-1591, p. 76-81, 2003.

BELL, T. The way we wash. Spectrum, IEEE, v. 22, n. 5, p. 106-108, 1985.

BERCHTOLD, M. et al. Awarepen - classafication probability and fuzziness in a context aware application. UIC 08: Proceedings of the 5th international conference on Ubiquitous Intelligence and Computing, p. 647-661, 2008.

BERNERS-LEE, T. Answers for Young People. 2009. Disponível em http://www.w3.org/People/Berners-Lee/Kids.html. Acessado em 2009.

BIGUS, J.; BIGUS, J. Constructing Intelligent Agents Using Java. [S.1.]: John Wiley and Sons, 2001.

BOIVIN, J. Demand side management - the role of the power utility. Pattern Recognition, v. 28 , n. 10, p. 1493-1497, 1995.

BOLZANI, C. Desenvolvimento De Um Simulador De Controle De Dispositivos Residenciais Inteligentes: Uma Introdução Aos Sistemas Domóticos. 2004. Universidade de São Paulo, Dissertação de Mestrado.

BOLZANI, C. Residências Inteligentes. [S.1.]: Editora Livraria da Física, 2004b. 
BOLZANI, C.; NETTO, M. The engineering of micro agents in smart environments. International Journal of Knowledge-based and Intelligent Engineering Systems, v. 13, n. 1, p. 31-38, 2009.

BOWDEN, S.; OFFER, A. Household appliance and the use of time: The united states and britain since the 1920s. The Economic History Review, v. 47, n. 4, p. 725-748, 1994.

BROOKMEYER, R. et al. Worldwide variation in the doubling time of alzheimer's disease incidence rates. Alzheimer's and Dementia, v. 4, n. 5, p. 316-323, 2008.

BROOKS, R. The intelligent room project. Cognitive Technology, Second International Conference on, p. 271-278, 1997.

BUCHER, G. The electric home of the future. Popular Mechanics, v. 72, n. 2, 1939.

BUSH, R.; GRIFFIN, T.; MEYER, D. Some Internet Architectural Guidelines and Philosophy. 2002. Disponível em http://tools.ietf.org/html/draft-ymbk-arch-guidelines-05. Acessado em 2009.

CARLINI, J. Measuring a building's iq. In: BERNADEN, J.; NEUBAUER, R. (Ed.). The Intelligent Building Sourcebook. [S.1.]: Prentice Hall, 1988.

CAWSON, A.; HADDON, L.; MILES, I. The Shape of Things to Consume: Delivering Information Technology Into the Home. [S.1.]: Avebury, 1995.

CHAN et al. Smart house automation system for the elderly and the disabled. Systems, Man and Cybernetics, 1995. Intelligent Systems for the 21st Century, IEEE International Conference on, v. 2, p. 1586-1589, 1995.

CHARLES, K.; HURST, E.; ROUSSANOV, N. Conspicuous Consumption and Race. [S.l.]: University of Chicago, 2007. Disponível em http://knowledge.wharton.upenn.edu /papers/1353.pdf. Acessado em 2009.

CHHETRI, M.; LOKE; KRISHNASWAMY, S. Mobile agents as smart virtual counterparts. Advanced Information Networking and Applications, 2004. AINA 2004. 18th International Conference on, v. 2, p. 270-273 Vol.2, 2004.

CHOI, J.; SHIN, D.; SHIN, D. Research and implementation of the context-aware middleware for controlling home appliances. Consumer Electronics, IEEE Transactions on, v. 51, n. 1, p. 301-306, 2005.

COOK, D. et al. Mavhome: An agent-based smart home. Pervasive Computing and Communications, 2003. (PerCom 2003). Proceedings of the First IEEE International Conference on, 2003.

COZZA, R. et al. Market Share: Smartphones, Worldwide, 3q08. [S.1.], 2008.

CUI, J. et al. Tracking multiple people using laser and vision. Intelligent Robots and Systems, 2005. (IROS 2005). 2005 IEEE/RSJ International Conference on, p. 2116-2121, 2005.

DARLING, S. Controlling your home by computer. COMPUTE!, n. 55, p. 30, 1984.

DAVIDSON, K. Take a tour of the bright home. The Computer Applications Journal, n. 25, 1992. 
DELONG, J. The Economic History of the Twentieth Century: Slouching Towards Utopia? 1997. Disponível em http://www.j-bradford-delong.net/TCEH. Acessado em 2009.

DEY, A.; SALBER, D.; ABOWD, G. A conceptual framework and a toolkit for supporting the rapid prototyping of context-aware applications. Human-Computer Interaction Journal, v. 16, n. 2-4, p. 97-166, 2001.

DOOTINGH, R. Esprit home systems project. Consumer Electronics, IEEE Transactions on, v. 36, n. 3 SN - 0098-3063, p. 612-618, 1990.

DOURISH, P. What we talk about when we talk about context. Personal and Ubiquitous Computing, v. 8, n. 1, p. 19-30, 2004.

DUCATEL, K. et al. Scenarios for Ambient Intelligence in 2010. 2001. Disponível em ftp://ftp.cordis.europa.eu/pub/ist/docs/istagscenarios2010.pdf. Acessado em 2009.

EIA. United States Energy Information Administration - Energy Consumption by Sector. 2009. Disponível em http://www.eia.doe.gov/emeu/mer/consump.html. Acessado em 2009.

FAIRCHILD. Fkpf12n80 Bi-Directional Triode Thyristor Planar Silicon. 2009. Disponível em http://www.fairchildsemi.com. Acessado em 2009.

FERREIRA, A. Novo Aurélio Século XXI: O Dicionário da Língua Portuguesa. 3. ed. [S.1.: s.n.], 1999.

FIEDLER, U. Semiconductors, the brain and muscles in home appliances. ZVEI Podium at Electronica 2004, 2004.

FISCHETTI, M.; HORGAN, J.; WALLICH, P. The superstructure: Designing for high-tech. Spectrum, IEEE, v. 22, n. 5, p. 36-50, 1985.

FLETCHER, C. Epicurean high-tech. Spectrum, IEEE, v. 22, n. 5, p. 81-85, 1985.

FORTY, A. Objects of Desire:Design and Society Since 1750. [S.1.]: Thames and Hudson, 1992.

FOX, A. et al. Integrating information appliances into an interactive workspace. Computer Graphics and Applications, IEEE, v. 20, n. 3, p. 54-65, 2000.

FRANK, A. The use of geographical information systems: The user interface is the system. In: HEARNSHAW, H.; MEDYCKYJ-SCOTT, D. (Ed.). Human Factors in Geographical Information Systems. [S.1.]: Belhaven Press, 1993. p. 3-14.

FRANK, A. The prevalence of objects with sharp boundaries in gis. In: BURROUGH, P.; FRANK, A. (Ed.). Geographic Objects with Indetermined Boundaries. [S.1.]: Taylor Francis, 1996. p. 29-40.

FREESCALE. Mma7341 Product Summary Page. 2009. Disponível em http://www.freescale.com. Acessado em 2009.

FREESCALE. Mp3h6115a. 2009. Disponível em http://www.freescale.com. Acessado em 2009. 
FREUNDSCHUH, S.; EGENHOFER, M. Human conceptions of spaces: Implications for geographic information systems. Transactions in GIS, v. 2, n. 4, p. 361-375, 1997.

FRIEDEWALD, M. et al. Perspectives of ambient intelligence in the home environment. Telematics and Informatics, v. 22, p. 221-238, 2005.

FRIEDEWALD, M.; COSTA, O. D. Science and technology roadmapping: Ambient intelligence in everyday life. Unpublished working paper, Institute for Prospective Technological Studies (IPTS), 2003.

FROHLICH, D.; KRAUT, R. The social context of home computing. In: HARPER, R. (Ed.). Inside the Smart Home. [S.1.]: Springer Verlag, 2003. p. 127-162.

FUJIEDA et al. A wireless home network and its application systems. Consumer Electronics, IEEE Transactions on, v. 46, n. 2 SN - 0098-3063, p. 283-290, 2000.

GARLAN, D. et al. Project aura: Toward distraction-free pervasive computing. Pervasive Computing, IEEE Pervasive Computing, IEEE, v. 1, n. 2, p. 22-31, 2002.

GELLINGS, C.; CHAMBERLIN, J. Demand-Side Management: Concepts and Methods. 2nd. ed. [S.1.]: Fairmont Press, 1993.

GLANCEY, J. The Car: A History of the Automobile. [S.1.]: Carlton Publishing Group, 2008.

GOTTFRIED, B.; GUESGEN, H.; HUBNER, S. Spatiotemporal reasoning for smart homes. In: AUGUSTO, J.; NUGENT, C. (Ed.). Designing Smart Homes. [S.1.]: Springer Verlag, 2006. p. 16-34.

GRATA, G. Microelectronics work in the esprit program. Proceedings of the IEEE, n. 9, p. 1410-1419, 1989.

GREEN, J.; MARVIN, S. Energy Efficiency and Home Automation. [S.1.]: University of New Castle, 1994. Disponível em www.ncl.ac.uk/guru/assets/documents/ewp3.pdf. Acessado em 2009.

HADDON, L. The home of the future today: The social origins of intelligent homes. In: ESSER, J.; FLEISCHMANN, G.; HEIMER, T. (Ed.). Soziale und Okonomische Konflikte in Standardisierungsprozessen. [S.1.]: Campus, 1995. p. 89-104.

HAMABE, R. et al. Conformance test concept for the home bus system. Consumer Electronics, IEEE Transactions on, v. 34, n. 3 SN - 0098-3063, p. 700-704, 1988.

HARA, K.; OMORI, T.; UENO, R. Detection of unusual human behavior in intelligent house. Neural Networks for Signal Processing, Proceedings of the 12th IEEE Workshop on, n. SN -, p. 697-706, 2002.

HARDYMENT, C. From Mangle to Microwave: The Mechanization of Household Work. [S.1.]: Blackwell Pub, 1988.

HARPER, R. Inside the smart home: Ideas, possibilities and methods. In: HARPER, R. (Ed.). Inside the Smart Home. [S.1.]: Springer Verlag, 2003. p. 1-13. 
HARWOOD, R.; SAYER, A.; HIRSCHFELD, M. Current and future worldwide prevalence of dependency, its relationship to total population, and dependency ratios. Bulletin of the World Health Organization, 2004.

HEIERMAN, E. et al. Moving From Internet Appliances to Internet Intelligent Environments: Challenges and Directions. 2008. Disponível em http://www.eecs.wsu.edu/ holder/courses/cse6362/pubs/heierman01.pdf. Acessado em 2009.

HEIERMAN, I.; COOK. Improving home automation by discovering regularly occurring device usage patterns. Data Mining, Third IEEE International Conference on, n. SN-, p. 537-540, 2003.

HELAL, A. et al. Atlas - architecture for sensor network based intelligent environments. ACM Transactions on Sensor Networks, 2007.

HELAL, S. et al. The gator tech smart house: A programmable pervasive space. Computer, $\mathrm{p}$. 50-60, 2005.

HILL, D. J. A wireless embedded sensor architecture for system-level optimization. UC Berkeley Technical Report, 2002.

HOLMEVIK, J. Compiling simula: A historical study of technological genesis. Annals of the History of Computing, IEEE, v. 16, n. 4, p. 25-37, 1994.

HOMEPLUG. Homeplug 1.0 Technology White Paper. [S.1.]: HomePlug Powerline Alliance, 2007. Disponível em http://www.homeplug.org/products/whitepapers/. Acessado em 2009.

HONEYWELL. HIH-5030/5031 Series Humidity Sensors. 2009. Disponível em http://sensing.honeywell.com/. Acessado em 2009.

HONG, J.; LANDAY, J. An infrastructure approach to context-aware computing. Human Computer Interaction, v. 16, n. 2, p. 287-303, 2001.

HORGAN, J. Electronic watchdog. Spectrum, IEEE, v. 22, n. 5, p. 43-46, 1985.

HORRIGAN, B. The home of tomorrow, 1927-1945. In: CORN, J. (Ed.). Imaging Tomorrow. [S.1.]: The MIT Press, 1988.

HORSTMANN. Horstmann History. [S.1.]: Horstmann Controls, 2008. Disponível em http://www.horstmann.co.uk/. Acessado em 2009.

IBGE. Projeção da população do Brasil por sexo e idade para o período 1980-2050 Revisão 2008. [S.1.], 2008.

IEEE. Standard for a Smart Transducer Interface for Sensors and Actuators Transducer to Microprocessor Communication Protocols and Transducer Electronic Data Sheet (Teds) Formats. 1998. Disponível em http://standards.ieee.org/regauth/1451. Acessado em 2009.

IEEE. NIST/IEEE Workgroup 1451. 1999. Disponível em http://ieee1451.nist.gov. Acessado em 2009. 
IEEE. Powering the Electrical Revolution: Women and Technology. [S.1.]: IEEE Museum, 2008. Disponível em http://www.ieee.org/museum. Acessado em 2009.

IEEE. IEEE Standard for Information Technology Specific Requirements Part 15.4: Wireless Medium Access Control (Mac) and Physical Layer (Phy) Specification. 2009. Disponível em http://standards.ieee.org/getieee802/802.15.html. Acessado em 2009.

INTILLE, S. Designing a home of the future. Pervasive Computing, IEEE, v. 1, n. 2, p. 76-82, 2002.

IPC. Generic Standard on Printed Board Design. [S.1.]: Association Connecting Electronics Industries, 1998. Disponível em www.ipc.org. Acessado em 2009.

ISHAK et al. Power line carrier technology and home automation. Research and Development, 2002. SCOReD 2002. Student Conference on, n. SN -, p. 505-508, 2002.

ISTAG. Ambient Intelligence: From Vision to Reality. [S.1.]: European Commission Information Society Technologies, 2003. Disponível em ftp://ftp.cordis.europa.eu. Acessado em 2009.

JOHNSON, M. The Body in the Mind: The Bodily Basis of Meaning, Imagination, and Reason. [S.1.]: University of Chicago Press, 1987.

JOHNSON, R. Building Plug and Play Networked Smart Transducers. 1997. Disponível em http://archives.sensorsmag.com/articles/1097/ieee1097/index.htm. Acessado em 2009.

JOVANOV, E. et al. A wireless body area network of intelligent motion sensors for computer assisted physical rehabilitation. Journal of Neuroengineering and Rehabilitation, v. 2, 2005.

JOY, V.; LAXMAN, V. Smart spaces: Indoor wireless location management system. Next Generation Mobile Applications, Services and Technologies, The 2007 International Conference on, p. 261-266, 2007.

KAPLINSKY, C. The d2b a one logical wire bus for consumer applications. Consumer Electronics, IEEE Transactions on, CE-27, n. 1, p. 102-116, 1981.

KHAN et al. Human tracking in multiple cameras. Computer Vision, Eighth IEEE International Conference on, v. 1, p. 331-336, 2001.

KIDD, C.; ORR, R.; ABOWD, G. The aware home: A living laboratory for ubiquitous computing research. Proceeding of 2nd International Workshop on Cooperative Buildings, n. 191, p. 198, 1999.

KING, J. et al. Atlas, a service-oriented sensor platform. IEEE International Workshop on Practical Issues in Building Sensor Network Applications, 2006.

$\mathrm{KOCH}$, J. et al. Indoor localisation of humans, objects, and mobile robots with rfid infrastructure. Hybrid Intelligent Systems, 7th International Conference on, p. 271-276, 2007.

KOLARS, J.; NYSTUEN, J. Physical Geography: Environment and Man. [S.1.]: McGraw Hill, 1975. 
KRUESI, W.; ROGERS, P. Residential control considerations. Consumer Electronics, IEEE Transactions on, CE-28, n. 4, p. 563-570, 1982.

LOCATELLI, M.; VIZZARI, G. Awareness in collaborative ubiquitous environments: The multilayered multi-agent situated system approach. ACM Transactions on Autonomous and Adaptive Systems (TAAS), v. 2, n. 4, p. 13, 2007.

LUGMAYR, A.; SAARINEN, T.; TOURNUT, J. The digital aura - ambient mobile computer systems. Parallel, Distributed, and Network-Based Processing, 2006. PDP 2006. 14th Euromicro International Conference on, 2006.

MARK, D. Human spatial cognition. In: MEDYCKYJ-SCOTT, D.; HEARNSHAW, H. (Ed.). Human Factors in Geographical Information Systems. [S.1.]: Belhaven Press, 1993. p. $51-60$.

MATEAS, M. et al. Engineering ethnography in the home. CHI '96: Conference companion on Human factors in computing systems, p. 283-284, 1996.

MATTOS, C. A abordagem etnográfica na investigação científica. Espaço (INES), v. 16, p. 53-58, 2001.

MAZUMDAR, S. et al. The home of the future: An ethnographic study of new information technologies in the home. Advances in Consumer Research, v. 28, n. 1, p. 88-97, 2001.

MELOSI, M. Thomas A. Edison and the Modernization of America. [S.1.]: Longman, 1990.

MOKYR, J. Why more work for mother? knowledge and household behavior, 1870-1945. The Journal of Economic History, v. 60, n. 1, p. 1-41, 2000.

MOSS, S. Fun Things - the Moss's House. 2006. Disponível em http://www.stirlingmoss.com /house.htm. Acessado em 2009.

MOZER, M. The neural network house:an environment that adapts to its inhabitants.

Proceedings of the American Association for Artificial Intelligence Spring Symposium on Intelligent Environments, p. 110-114, 1998.

MOZER, M. Lessons from an adaptive home. In: COOK, D.; DAS, S. (Ed.). Smart Environments Technologies, Protocols, and Applications. [S.1.]: Wiley InterScience, 2005. p. 273-294.

MUNK-STANDER M.S., T. N. J. Implementing a Zigbee Protocol Stack and Light Sensor in Tinyos. 2005. University of Copenhagen, Projeto de Formatura.

MURATA. Pyroelectric Infrared Sensors. 2009. Disponível em http://www.murata.com/products/catalog/pdf/s21e.pdf. Acessado em 2009.

NELSON, R.; GREEN, I. Tracking objects using recognition. Pattern Recognition, International Conference on, v. 2, 2002.

NEWSHAM, G.; MANCINI, S.; MARCHAND, R. Detection and acceptance of demandresponsive lighting in offices with and without daylight. The Journal of the Illuminating Engineering Society of North America, v. 4, n. 3, 2008. 
NICKLES, S. Preserving women: Refrigerator design as social process in the 1930s. The Society for the History of Technology, 2002.

NISHIDA, Y. et al. 3d ultrasonic tagging system for observing human activity. Intelligent Robots and Systems, International Conference on, v. 1, p. 785-791, 1927.

NORBISRATH, U. et al. Fujaba-based tool development for ehome systems. Electronic Notes in Theoretical Computer Science, v. 127, p. 89-99, 2005.

NORVIG, P.; RUSSEL, S. Artificial Intelligence: A Modern Approach. [S.1.]: Prentice Hall, 2002.

NUGENT, C. et al. Editorial home automation as a means of independent living. Automation Science and Engineering, IEEE Transactions on [see also Robotics and Automation, IEEE Transactions on], v. 5, n. 1, p. 1-9, 2008.

NWHM. Partners in Winning the War: American Women in World War Ii. [S.1.]: National Women History Museum, 2008. Disponível em http://www.nmwh.org. Acessado em 2009.

O'BRIEN, J. et al. At home with the technology: An ethnographic study of a set-top-box trial. ACM Transaction on Computer Human Interaction, v. 6, n. 3, p. 282-308, 1999.

ONU. Population Ageing 2006. [S.1.]: United Nations - Department of Economic and Social Affairs, 2006. Disponível em http://www.unpopulation.org. Acessado em 2009.

ORR, R.; ABOWD, G. The smart floor: A mechanism for natural user identification and tracking. Conference on Human Factors in Computing Systems (CHI 200), 2000.

OSBA. White Paper. [S.1.]: MIT Open Source Building Alliance, 2008. Disponível em http://architecture.mit.edu. Acessado em 2009.

PAUWELS, E.; SALAH, A.; TAVENARD, R. Sensor networks for ambient intelligence. Multimedia Signal Processing, 2007. MMSP 2007. IEEE 9th Workshop on, p. 13-16, 2007.

PENTLAND. Smart rooms, smart clothes. Pattern Recognition, Fourteenth International Conference on, v. 2, n. SN -, p. 949-953, 1998.

PERRY, T. Eaglecrest: A commuter's dream. Spectrum, IEEE, v. 22, n. 5, p. 69-73, 1985.

PERRY, T. Portia's perfect pad: Superhigh-tech. Spectrum, IEEE, v. 22, n. 5, p. 56-63, 1985.

PHILIPOSE, M. et al. Inferring activities from interactions with objects. Pervasive Computing, IEEE, p. 50-57, 2004.

PHILIPS. Lâmpadas Incandescentes Standard. [S.1.]: Philips do Brasil, 2008. Disponível em http://www.luz.philips.com. Acessado em 2009.

PILICH, B. Engineering Smart Houses. 2004. Technical University of Denmark, PhD Thesis.

POTOCNIK, B.; DIVJAK, M. Automated recognition of foodstuff placed into refrigerator. Electrotechnical Conference, 2004. MELECON 2004. Proceedings of the 12th IEEE Mediterranean, v. 1, p. 331-334, 2004. 
PRINCE, R.; SCHIFF, L. The Middle-Class Millionaire: The Rise of the New Rich and How They Are Changing America. [S.1.]: Broadway Books, 2008.

RICQUEBOURG, V. et al. The smart home concept : Our immediate future. E-Learning in Industrial Electronics, 2006 1ST IEEE International Conference on, p. 23-28, 2006.

ROBINSON, J.; GODBEY, G. Time for Life: The Surprising Ways Americans Use Their Time. [S.1.]: Pennsylvania State University Press, 1999.

RODIN, J.; LANGER, E. Long-term effects of a control-relevant intervention with the institutionalized aged. Journal of Personality and Social Psychology, v. 35, n. 12, p. 897-902, 1977.

ROHM. Bd1603fve Sensor Ics. 2009. Disponível em http://www.rohm.com /products/databook/sensor/pdf/bh1603fvc-e.pdf. Acessado em 2009.

ROMAN C.H., R. C. M. Gaia: A middleware infrastructure to enable active spaces. National Science Foundation, v. 1, 2002.

ROY, N. et al. A cooperative learning framework for mobility-aware resource management in multi-inhabitant smart homes. Mobile and Ubiquitous Systems: Networking and Services, 2005. MobiQuitous 2005. The Second Annual International Conference on, p. 393-403, 2005.

RUDDARRAJU, R.; HARO, A.; ESSA, I. Fast multiple camera head pose tracking. Vision Interface, 2003.

RUSSO, J. et al. Smartwave intelligent meal preparation system to help older people live independently. Second International Conference on Smart homes and health Telematic (ICOST2004), 2004.

RYE, D. My life at x10. HomeToys EMagazine, v. 4, n. 5, 1999.

SAKAMURA, K. The tron intelligent house. IEEE Micro, v. 10, n. 2, p. 6-7, 1990.

SATYANARAYANAN, M. Pervasive computing: Vision and challenges. Personal Communications, IEEE [see also IEEE Wireless Communications], v. 8, n. 4, p. 10-17, 2001.

SCHERF, K. European Smart-Home Initiatives Get a Boost From Nokia. [S.1.]: Parks Associates, 2008. Disponível em http://hiddenwires.co.uk/resourcesarticles2009/articles2009010202.html. Acessado em 2009.

SHADBOLT, N. Ambient intelligence. IEEE Intelligent Systems, 2003.

SHAFER, S.; BRUMITT, B.; CADIZ, J. Interaction issues in context-aware intelligent environments. Human Computer Interaction, v. 16, n. 2, p. 363-378, 2001.

SHAFER, S. et al. The easyliving intelligent environment system. Ubiquitous Computing and The Role of Geometry, 2000.

SHAHI, A.; GARDNER, M.; CALLAGHAN, V. Supporting mobile sessions across pervasive smart space environments. Intelligent Environments, 2005. The IEE International Workshop on (Ref. No. 2005/11059), n. SN - 0537-9989, p. 210-217, 2005. 
SHERIDAN, T. Humans and Automation. [S.1.]: Wiley, 2002.

SMITH, A. The Theory of Moral Sentiments. 2008. ed. [S.1.]: BiblioLife, 1759.

SPRENGER, E.; WEBB, P. Persuading the housewife to use electricity? an interpretation of material in the electricity council archives. The British Journal for the History of Science, v. 26 , n. 1 , p. 55-65, 1993.

STANKOVSKI, V.; TRNKOCZY, J. Application of decision trees to smart homes. In: NUGENT, C.; AUGUSTO, J. (Ed.). Designing Smart Homes. [S.1.]: Springer, 2006. p. $132-145$.

STIMSON, J. T. A house of magic. Popular Mechanics, 1954.

SYSTRONIX. Jstamp. Real-Time Native Java Module. 2005. Disponível em http://jstamp.systronix.com/. Acessado em 2009.

TEXAS. Texas Instruments Low-Power Rf System-On-Chip for Zigbee Applications. [S.1.]: Texas Instruments, 2009. Disponível em http://www.ti.com/corp/docs/landing/cc2431/index.htm. Acessado em 2009.

TOLMIE, P. et al. Towards the unremarkable computer: Making technology at home in domestic routine. In: HARPER, R. (Ed.). Inside Inside the Smart Home. [S.1.]: Springer, 2003.

VEBLEN, T. The Theory of the Leisure Class. [S.1.]: Oxford University Press, 2008.

VENKATESH, A. Computers and other interactive technologies for the home. Communications of the ACM, v. 39, n. 12, 1996.

VENKATESH, A. Smart home concepts: Current trends. CRITO Working paper, 2003.

VENKATESH, A.; BEHAIRY, N.; CHEN, S. Childrens Experiences in Electronic

Environments. 2002. Disponível em http://www.crito.uci.edu/noah/publications.htm.

Acessado em 2009.

VENKATESH, A.; KRUSE, E.; SHIH, E. The networked home: An analysis of current developments and future trends. Cogn Tech Work, v. 5, 2003.

VENKATESH, A.; VITALARI, N. A longitudinal analysis of computing in the home. In Home informatics and Telematics: Information, Technology and Society, 1990.

VENKATESH, N. A. Project Noah a Longitudinal Analysis of Compu-

ting in the Home. [S.1.]: University of California Irvine, 1990. Disponível em www.crito.uci.edu/noah/publications.htm. Acessado em 2009.

WACKS, K. International development of home automation standards. Consumer Electronics, 1992. Digest of Technical Papers. ICCE., IEEE 1992 International Conference on, p. 274-275, 1992.

WAN, J. et al. A new method of determination of indoor temperature and relative humidity with consideration of human thermal comfort. Building and Environment, v. 44, n. 2, p. 411417, 2009. 
WANT, R. et al. The active badge location system. ACM Transactions on Information Systems, 1992.

WEBSTER. Webster's New World Medical Dictionary. [S.l.]: Wiley Publishing, 2008.

WEISER, M. The computer for the 21st century. Scientific American, v. 265, n. 3, p. 66-75, 1991.

WEISER, M. Some computer science issues in ubiquitous computing. Commun. ACM, v. 36, n. 7, p. 75-84, 1993.

WEISER, M.; BROWN, J. The coming age of calm technology. In: DENNING, P.; METCALFE, R. (Ed.). Beyond Calculation: The Next Fifty Years of Computing. [S.1.]: Springer Verlag, 1997.

WOLF, M. The top ten drivers of the converged home network. In-Stat / MDR, 2003.

WOZNIAK, S.; SMITH, G. IWoz. [S.1.]: W.W. Norton and Company, 2006.

XBOW. Mica Wireless Measurement System. 2002. Disponível em http://www.xbow.com/. Acessado em 2009.

YAKAL, K. The computerized home. COMPUTE!, n. 70, p. 26, 1986.

YANG, H.; JANSEN, E.; HELAL, A. A comparison of two programming models for pervasive computing. Workshop on Ubiquitous Networking and Enablers to Context Aware Services, 2006.

YOUNGBLOOD, G.; HOLDER, L.; COOK, D. Managing adaptive versatile environments. Pervasive Computing and Communications, 2005. PerCom 2005. Third IEEE International Conference on, p. 351-360, 2005.

ZHANG, Y. et al. A context-aware ami system based on mas model. Intelligent Information Hiding and Multimedia Signal Processing, 2006. IIH-MSP '06. International Conference on, p. 703-706, 2006.

ZIGBEE. Zigbee Cluster Library Specification. [S.1.]: ZigBee Standards Organization, 2007. Disponível em http://www.zigbee.org. Acessado em 2009.

ZIGBEE. Zigbee Home Automation Public Application Profile. [S.1.]: ZigBee Alliance, 2007. Disponível em www.zigbee.org. Acessado em 2009.

ZIGBEE. Zigbee Specification Document 053474r17. [S.1.]: ZigBee Alliance, 2008. Disponível em http://www.zigbee.org. Acessado em 2009.

ZIMMER, T. Towards a better understanding of context attributes. Pervasive Computing and Communications Workshops, 2004. Proceedings of the Second IEEE Annual Conference on, p. 23-27, 2004. 